This report was prepared as an account of work sponsored by an agency of the United States Government. Neither the United States Government nor any agency thereof, nor any of their employees, makes any warranty, express or implied, or assumes any legal liability or responsibility for the accuracy, completeness, or usefulness of any information, apparatus, product, or process disclosed, or represents that its use would not infringe privately owned rights. Reference herein to any specific commercial product, process, or service by trade name, trademark, manufacturer, or otherwise does not necessarily constitute or imply its endorsement, recommendation, or favoring by the United States Government or any agency thereof. The views and opinions of authors expressed herein do not necessarily state or reflect those of the United States Government or any agency thereof.

\title{
HIGH CYCLE FATIGUE BEHAVIOR OF INCOLOY 800H IN A SIMULATED HIGH-TEMPERATURE GAS-COOLED REACTOR HELIUM ENVIRONMENT
}

\author{
P. Soo, R.l. Sabatini, L.G. Epel, and J.R. Hare, SR.
}

\section{Manuscript Completed - December 1979 \\ Date Published - January 1980}

\author{
HTGR SAFETY DIVISION, DEPARTMENT OF NUCLEAR ENERGY \\ BROOKHAVEN NATIONAL LABORATORY, ASSOCIATED UNIVERSITIES, INC. \\ UPTON, NEW YORK 11973
}

\section{PREPARED FOR THE UNITED STATES NUCLEAR REGULATORY COMMISSION DIVISION OF REACTOR SAFETY RESEARCH, OFFICE OF NUCLEAR REGULATORY RESEARCH UNDER CONTRACT NO. DE-AC02-76CH00016 \\ NRC FIN NO. A-3016}




\section{NOTICE}

This report was prepared as an account of work sponsored by an agency of the United States Government Neither the United States Government nor any agency thereof, or any of their employees, makes any warranty, expressed or implied, or assumes any legal liability or responsibulity for any third party's use, or the results of such use, of any information, apparatus, product or process disclosed in this report, or represents that its use by such third party would not infringe privately owned rights

The views expressed in this report are not necessarily those of the US Nuclear Regulatory Commission

\section{Avallable from}

GPO Sales Program

Division of Technical Information and Document Control

US Nuclear Regulatory Commission

Washington, D C 20555

and

National Technical Information Service

Springfield, Virgınıa 22161 
DISCLAIMER

This report was prepared as an account of work sponsored by an agency of the United States Government. Neither the United States Government nor any agency Thereof, nor any of their employees, makes any warranty, express or implied, or assumes any legal liability or responsibility for the accuracy, completeness, or usefulness of any information, apparatus, product, or process disclosed, or represents that its use would not infringe privately owned rights. Reference herein to any specific commercial product, process, or service by trade name, trademark, manufacturer, or otherwise does not necessarily constitute or imply its endorsement, recommendation, or favoring by the United States Government or any agency thereof. The views and opinions of authors expressed herein do not necessarily state or reflect those of the United States Government or any agency thereof. 


\section{DISCLAIMER}

Portions of this document may be illegible in electronic image products. Images are produced from the best available original document. 
TABLE OF CONTENTS

SECTION

Page

List of Tables iv

List of Figures

v

ABSTRACT

$x i$

1. INTRODUCTION

2. EXPERIMENTAL PROCEDURES

3. RESULTS

3.1 Metallurgical Evaluations on Specimens Fractured at $760^{\circ} \mathrm{C}\left(1400^{\circ} \mathrm{F}\right)$

3.1.1 Fractography

3.1.2 Optical Microscopy

3.1.3 Scanning Electron Microscope/Microprobe Analyses

3.1.4 Microhardness Evaluations

3.2 Metallurgical Evaluations on Specimens Fractured at $649^{\circ} \mathrm{C}\left(1200^{\circ} \mathrm{F}\right)$

3.3 Metallurgical Evaluations on Specimens Fractured at $871^{\circ} \mathrm{C}\left(1600^{\circ} \mathrm{F}\right)$

4. DISCUSSION

4.1 Fatigue Strength of Unaged Incoloy $800 \mathrm{H}$ 46

4.1.1 Effect of Test Environment on Fatigue Strength

4.1.2 Anomalous Environmental Effect at $649^{\circ} \mathrm{C}\left(1200^{\circ} \mathrm{F}\right)$

4.1.3 Fatigue Limit Effects

4.2 Fatigue Strength of Pre-aged Incoloy $800 \mathrm{H}$

4.2.1 Effects of Aging on Fatigue Strength at $760^{\circ} \mathrm{C}$ $\left(1400^{\circ} \mathrm{F}\right)$ 
TABLE OF CONTENTS (Continued)

SECTION

4.2.2 Corrosion-Fatigue Effects for Long Term Tests

5. CONCLUSIONS

ACKNOWL EDGEMENTS

TABLES

REFERENCES

\section{LIST OF TABLES}

Page

Table 1. Chemical Composition of Incoloy $800 \mathrm{H}$ Test Material (Heat HH7427A).

Table 2. High Cycle Fatigue Data for Incoloy $800 \mathrm{H}$ as a Function of Test Environment and Temperature.

Table 3. High Cycle Fatigue Data for Incoloy $800 \mathrm{H}$ Thermally Aged in HTGR Helium Prior to Testing in the Same Environment. 


\section{LIST OF FIGURES}

Page

Figure 1 Test Capsule for In-Helium Fatigue Tests.

Figure 2 Effect of an HTGR Helium Environment on the High Cycle Fatigue Strength of Incoloy $800 \mathrm{H}$.

Figure 3 Temperature Dependence of the $10^{8}$ Cycle Fatigue Strength for Incoloy $800 \mathrm{H}$ as a Function of Test Environment.

Figure 4 Effect of Thermal Aging in Helium on the High Cycle Fatigue of Incoloy $800 \mathrm{H}$ at $760^{\circ} \mathrm{C}$.

Figure 5 Effect of Pretest Thermal Aging in HTGR Helium on the $10^{8}$ Cycle Fatigue Strength for Incoloy $800 \mathrm{H}$ at $760^{\circ} \mathrm{C}$ $\left(1400^{\circ} \mathrm{F}\right)$

Figure 6 Fractographs of Incoloy $800 \mathrm{H}$ High Cycle Fatigue Specimens Tested at $760^{\circ} \mathrm{C}\left(1400^{\circ} \mathrm{F}\right)$ for Various Test Environments and Stress Levels. Magnifications Approximately $6 \mathrm{X}$.

Figure 7 Crack Initiation Points in Incoloy $800 \mathrm{H}$ High Cycle Fatigue Specimens Tested at $760^{\circ} \mathrm{C}\left(1400^{\circ} \mathrm{F}\right)$ for Various Test Environments and Stress Levels. Magnifications $60 \mathrm{X}$.

Figure 8 Internal Crack Initiation in an Incoloy $800 \mathrm{H} \mathrm{High} \mathrm{Cycle}$ Fatigue Specimen Pre-aged in HTGR Helium for $6000 \mathrm{~h} / 760^{\circ} \mathrm{C}$ $\left(1400^{\circ} \mathrm{F}\right)$ and Tested in Same Environment at $760^{\circ} \mathrm{C}$. Magnifications 10X and 100X, Respectively.

Figure 9 Surface 0xidation Characteristics in Incoloy $800 \mathrm{H} \mathrm{High}$ Cycle Fatigue Specimens Tested at $760^{\circ} \mathrm{C}\left(1400^{\circ} \mathrm{F}\right)$ for Various Test Environments and Stress Levels, Magnifications $70 x$. 


\section{LIST OF FIGURES (Continued)}

Page

Figure 10 Striations in Incoloy $800 \mathrm{H} \mathrm{High} \mathrm{Cycle} \mathrm{Fatigue} \mathrm{Specimens}$ Tested at $760^{\circ} \mathrm{C}\left(1400^{\circ} \mathrm{F}\right)$ for Various Test Environments and Stress Levels. Magnifications $150 \mathrm{X}$.

Figure 11 Appearances of Edges of Fracture Surfaces in an Incoloy $800 \mathrm{H} \mathrm{High} \mathrm{Cycle} \mathrm{Fatigue} \mathrm{Specimen} \mathrm{(MNF-221)} \mathrm{Pre-aged} \mathrm{in}$ HTGR Helium for $1500 \mathrm{~h} / 760^{\circ} \mathrm{C}\left(1400^{\circ} \mathrm{F}\right)$ and Tested in Same Environment; (A) Magnification 240X, (B) Magnification $600 x$

Figure 12 Stage III Dimple Formation in Incoloy $800 \mathrm{H} \mathrm{High} \mathrm{Cycle}$ Fatigue Specimens Tested at $760^{\circ} \mathrm{C}\left(1400^{\circ} \mathrm{F}\right)$ for Various Test Environments and Stress Levels. Magnification $150 x$

Figure 13 0xidation Products in Fracture Surfaces of Incoloy $800 \mathrm{H}$ High Cycle Fatigue Specimens Tested at $760^{\circ} \mathrm{C}\left(1400^{\circ} \mathrm{F}\right)$ for Various Test Environments and Stress Levels. Magnifications $1400 x$.

Figure 14 Recrystallization and Cracking in Incoloy $800 \mathrm{H} \mathrm{High}$ Cycle Fatigue Specimens Tested at $760^{\circ} \mathrm{C}\left(1400^{\circ} \mathrm{F}\right)$ for Various Test Environments and Stress Levels. Magnifications $350 x$.

Figure 15 Scanning Electron Microscope/Microprobe Scans Through the Surfaces of Incoloy $800 \mathrm{H}$ High Cycle Fatigue Specimens as a Function of Test Environment and Pretest Thermal Aging Time. Aging and Test Temperature was $760^{\circ} \mathrm{C}\left(1400^{\circ} \mathrm{F}\right)$. Magnifications $425 \mathrm{X}$. 
LIST OF FIGURES (Continued)

Page

Figure 16 Scanning Electron Microscope/Microprobe Scans Through the Surface of Incoloy $800 \mathrm{H}$ Specimen After Exposure to HTGR Helium Environment at $760^{\circ} \mathrm{C}\left(1400^{\circ} \mathrm{F}\right)$ for $1500 \mathrm{~h}$. Magnifications $800 x$.

Figure 17 Knoop Microhardness Traverses in a Sectioned Incoloy $800 \mathrm{H} \mathrm{High} \mathrm{Cycle} \mathrm{Fatigue} \mathrm{Specimen} \mathrm{Tested} \mathrm{at} 649^{\circ} \mathrm{C}$ $\left(1200^{\circ} \mathrm{F}\right)$ in Air; Specimen MNF-164. Magnification $250 x$.

Figure 18 Surface Microhardness Profiles for Incoloy $800 \mathrm{H}$ Fatigue Specimens as a Function of Test Temperature, Test Environment and Thermal Pre-aging Time.

Figure 19 Schematic of Surface Hardness Profiles for Incoloy $800 \mathrm{H}$ Fatigue Specimens as a Function of Test Temperature, Test Environment and Thermal Pre-aging Condition.

Figure 20 Effect of Thermal Aging and Cyclic Stressing on the Microhardness of Incoloy $800 \mathrm{H}$.

Figure 21 Effect of Test Environment on the Fractography of Incoloy $800 \mathrm{H}$ High Cycle Fatigue Specimens Tested at $649^{\circ} \mathrm{C}\left(1200^{\circ} \mathrm{F}\right)$; (A) Specimen MNF-184 Tested in Air, (B) Specimen MNF-163 Tested in HTGR Helium. Magnifications $10 x$.

Figure 22 Effect of Test Environment on the Crack Initiation Regions in Incoloy $800 \mathrm{H} \mathrm{High} \mathrm{Cycle} \mathrm{Fatigue} \mathrm{Specimens}$ Tested at $649^{\circ} \mathrm{C}\left(1200^{\circ} \mathrm{F}\right)$; (A) Specimen MNF-184 Tested 


\section{LIST OF FIGURES (Continued)}

Figure 22 in Air, (B) Specimen MNF-163 Tested in HTGR Helium.

(Cont'd.) Magnifications $100 \mathrm{X}$.

Figure 23 Effect of Test Environment on the Nature of Striations in Incoloy $800 \mathrm{H} \mathrm{High} \mathrm{Cycle} \mathrm{Fatigue} \mathrm{Specimens} \mathrm{Tested} \mathrm{at}$ $649^{\circ} \mathrm{C}\left(1200^{\circ} \mathrm{F}\right)$; (A) Specimen MNF-184 Tested in Air, (B) Specimen MNF-163 Tested in HTGR Helium. Magnifications $240 x$.

Figure 24 Appearances of Edges of Fracture Surfaces in Incoloy $800 \mathrm{H} \mathrm{High} \mathrm{Cycle} \mathrm{Fatigue} \mathrm{Specimens} \mathrm{Tested} \mathrm{at} 649^{\circ} \mathrm{C}$ $\left(1200^{\circ} \mathrm{F}\right)$; (A) Specimen MNF-184 Tested in Air, (B) Specimen MNF-163 Tested in HTGR Helium. Magnification $120 x$.

Figure 25 Stage III Dimple Formation in Incoloy $800 \mathrm{H} \mathrm{High} \mathrm{Cycle}$ Fatigue Specimens Tested at $649^{\circ} \mathrm{C}\left(1200^{\circ} \mathrm{F}\right)$; (A) Specimen MNF-184 Tested in Air, (B) Specimen MNF-163 Tested in HTGR Helium. Magnification 240X.

Figure 26 oxidation Products in the Fracture Surface of an Incoloy 800H High Cycle Fatigue Specimen (MNF-163) Tested in HTGR Helium at $649^{\circ} \mathrm{C}\left(1200^{\circ} \mathrm{F}\right)$. Magnification $2400 \mathrm{X}$.

Figure 27 Fractographs of Incoloy $800 \mathrm{H}$ High Cycle Fatigue Specimens Tested at $871^{\circ} \mathrm{C}\left(1600^{\circ} \mathrm{F}\right)$ for Various Test Environments and Stress Levels. Cracks Propagated in Upward Direction. Magnifications Approximately $10 x$. 
Figure 28 Crack Initiation Points in Incoloy $800 \mathrm{H} \mathrm{High} \mathrm{Cycle}$ Fatigue Specimens Tested at $871^{\circ} \mathrm{C}\left(1600^{\circ} \mathrm{F}\right)$ for Various Test Environments and Stress Levels. Magnifications $100 x$.

Figure 29 Crack Propagation Characteristics in Incoloy $800 \mathrm{H}$ High Cycle Fatigue Specimens Tested at $871^{\circ} \mathrm{C}\left(1600^{\circ} \mathrm{F}\right)$ for Various Test Environments and Stress Levels. Cracks Propagated from Left to Right. Magnifications $240 x$.

Figure 30 Appearance of Edges of Fracture Surfaces in Incoloy $800 \mathrm{H} \mathrm{High} \mathrm{Cycle} \mathrm{Fatigue} \mathrm{Specimens} \mathrm{Tested} \mathrm{at} 871^{\circ} \mathrm{C}$ $\left(1600^{\circ} \mathrm{F}\right)$ for Various Test Environments and Stress Levels. Cracks Propagated from Left to Right. Magnifications $120 x$.

Figure 31 Scanning Electron Microscope/Microprobe EDS X-ray Scan of Oxidation Products in the Fracture Surface of Incoloy $800 \mathrm{H} \mathrm{High} \mathrm{Cycle} \mathrm{Fatigue} \mathrm{Specimen} \mathrm{(MNF-188)} \mathrm{Pre-aged} \mathrm{in}$ HTGR Helium for $6000 \mathrm{~h} / 760^{\circ} \mathrm{C}\left(1400^{\circ} \mathrm{F}\right)$ and Tested in the Same Environment at $760^{\circ} \mathrm{C}$. Magnification $1000 \mathrm{X}$.

Figure 32 Surface Recrystallization Characteristics in Incoloy $800 \mathrm{H} \mathrm{High} \mathrm{Cycle} \mathrm{Fatigue} \mathrm{Specimens} \mathrm{Tested} \mathrm{at} 871^{\circ} \mathrm{C}$ $\left(1600^{\circ} \mathrm{F}\right)$. Magnifications 500X. 
Figure 33 Sections Through the Fracture Surfaces of Incoloy $800 \mathrm{H}$ High Cycle Fatigue Specimens Tested at $871^{\circ} \mathrm{C}\left(1600^{\circ} \mathrm{F}\right)$; (A) Intergranular Failure in Specimen MNF-232 Tested in Air, (B) Transgranular Failure in Specimen MNF-237 Tested in HTGR Helium. Magnifications 100X.

Figure 34 Effect of Annealing Temperature on the Amount of Stress Relief in Cold Worked Austenitic Stainless Steels.

Figure 35 Recrystallization and Cracking in Incoloy $800 \mathrm{H} \mathrm{High}$ Cycle Fatigue Specimens Tested at $760^{\circ} \mathrm{C}\left(1400^{\circ} \mathrm{F}\right)$ for Various Test Environments and Stress Levels. Magnifications $1000 x$.

Figure 36 Nature of Fatigue Cracks in Incoloy $800 \mathrm{H} \mathrm{High} \mathrm{Cycle}$ Fatigue Specimens; (A) Corrosion-Fatigue Crack in Specimen MNF-238 Tested at $871^{\circ} \mathrm{C}\left(1600^{\circ} \mathrm{F}\right)$ in $\mathrm{HTGR}$ Helium, (B) Regular Fatigue Crack in Specimen MNF-138 Tested at $760^{\circ} \mathrm{C}\left(1400^{\circ} \mathrm{F}\right)$ in Air. Magnifications $500 \mathrm{X}$.

Figure 37 Corrosion-Fatigue Cracks in Incoloy $800 \mathrm{H} \mathrm{High} \mathrm{Cycle}$ Fatigue Specimens Tested in HTGR Helium; (A) Specimen MNF-221 Pre-aged in HTGR Helium for $3000 \mathrm{~h} / 760^{\circ} \mathrm{C}\left(1400^{\circ} \mathrm{F}\right)$, Magnification $1000 X$, (B) Specimen MNF-221 Pre-aged in HTGR Helium for $1500 \mathrm{~h} / 760^{\circ} \mathrm{C}\left(1400^{\circ} \mathrm{F}\right)$, Magnification 1000X, (C) Specimen MNF-224 Pre-aged in HTGR Helium for $1500 \mathrm{~h} / 760^{\circ} \mathrm{C}\left(1400^{\circ} \mathrm{F}\right)$, Magnification $1000 \mathrm{X}$. 
The current study was an attempt to evaluate the high cycle fatigue strength of Incoloy $800 \mathrm{H}$ in a High-Temperature Gas-Cooled Reactor helium environment containing significant quantities of moisture. As-heat-treated and thermally-aged materials were tested to determine the effects of long térm corrosion in the helium test gas. Results from in-helium tests were compared to those from a standard air environment. It was found that the mechanisms of fatigue failure were very complex and involved recovery/recrystallization of the surface ground layer on the specimens, sensitization, hardness changes, oxide scale integrity, and oxidation at the tips of propagating cracks. For certain situations a corrosion-fatigue process seems to be controlling. However, for the helium environment studied, there was usually no aging or test condition for which air gave a higher fatigue strength. 


\section{INTRODUCTION}

Incoloy 800 is a high nickel iron base alloy which is being increasingly used in the power and chemical industries as a material which bridges the gap between the relatively inexpensive austenitic stainless steels, such as Types 304 and 316 which possess excellent fabricability and ductility, and the more expensive high nickel superalloys which possess superior strength and corrosion resistance. One of the more important applications of Incoloy 800 is in advanced nuclear reactor steam generator systems where high temperature strength, and resistance to general corrosion and stress corrosion cracking are prime requisites.

In the steam generators of the High Temperature Gas Cooled Reactor (HTGR) the alloy is used in the fabrication of tubing and other selected components. These are subjected to maximum design temperatures in excess of $760^{\circ} \mathrm{C}$ $\left(1400^{\circ} \mathrm{F}\right) .^{1}$ Corrosion of the steam generator tubes occurs on both the steam side and also on the helium side. In the latter case, the corrosion results from the presence of impurities such as $\mathrm{CO}, \mathrm{CO}_{2}, \mathrm{CH}_{4}, \mathrm{H}_{2}$ and $\mathrm{H}_{2} \mathrm{O} .{ }^{2-14}$ Not only are the absolute quantities of these impurities important, but their ratios could also determine the corrosion process. For example, a 1 ow $\mathrm{H}_{2} / \mathrm{H}_{2} \mathrm{O}$ ratio encourages oxidation and 10 w concentrations of $\mathrm{CO}$ and $\mathrm{CH}_{4}$ promote decarburization. Such corrosion processes are likely to significantly affect the fatigue strength of a structural metal since fatigue fracture is usually a surface initiated mechanism. In particular, any intergranular corrosion would form a notch which, as a stress raiser, could cause premature fatigue failure.

In contrast to HTGR helium environments, corrosion in air is relatively straightforward. Protective oxide scales are rapidly formed at elevated temperatures, and these restrict the formation of intergranular corrosion cracks. 
It has also been shown that oxides formed in air effectively minimize carbon transfer at metal surfaces. 10

Currently, very few data are available on fatigue strengths of structural alloys in HTGR helium test environments. This presents an important problem since testing over a range of different impurity levels is required before an understanding can be obtained of the complex interactions between corrosion and fatigue. The limited prior work has usually been focussed on relatively pure helium environments which are anticipated in ideally operating HTGR systems. Little attention has been paid to environments containing quantities of water which could be present if significant leaks occur into the primary system. Since oxidation usually accelerates mechanical failure 3,7 it was decided to investigate the effects of water ingress accidents on the fatigue strength of HTGR structural metals such as Incoloy $800 \mathrm{H}$, Hastelloy $X$ and $2-1 / 4 \mathrm{Cr}-1$ Mo steel. The latter two materials will be the subject of later reports and will not be discussed here.

In the current study, only high cycle fatigue (cycles to failure, $N_{f} \gtrsim 10^{4}$ was considered. This type of deformation results when vibrations or oscillations occur as a result of acoustic, mechanical or fluid flow excitation. In certain instances cyclic mechanical stresses can also be induced in metals in contact with a coolant which has small temperature fluctuations.

The scope of this study involves a determination of the factors controlling fatigue failure in a simulated impure helium environment, with special emphasis on long term tests so that any effects caused by extensive corrosion and thermally induced changes in material microstructure can be identified. In support of these goals a series of specimens pre-aged for varying lengths of time in the helium test gas were fatigue tested and compared to non-aged 
samples. This procedure gave prototypic corrosion and metallurgical changes without the need to expend valuable time in an actual fatigue machine. All in-helium test data were evaluated with respect to air tested control samples.

\section{EXPERIMENTAL PROCEDURES}

Fatigue tests were conducted in Materials Test Systems closed loop electrohydraulic machines operating under load control in the push-pull mode. A sinusoidal load waveform was used and the cycling rate throughout was $40 \mathrm{~Hz}$. At the beginning of each test the load was gradually increased from zero to the predetermined value in a total time of about 10 seconds; i.e. the steady state load was achieved after about 400-500 cycles.

Specimens were fabricated from a master heat of Incoloy $800 \mathrm{H}$, the $\mathrm{H}$ designation being an added specification requiring a minimum grain size of ASTM 5 , and a minimum carbon level of 0.05 wt. percent in order to ensure optimum high temperature creep strength. Table 1 gives the composition of the material studied which was in the form of $1.27 \mathrm{~cm} .(0.5 \mathrm{in.})$ diameter rod. The material was solution annealed at $1150^{\circ} \mathrm{C}\left(2100^{\circ} \mathrm{F}\right)$ and water quenched. Specimens were surface ground to a contoured hourglass finish with a minimum diameter of $0.635 \mathrm{~cm} .(0.25 \mathrm{in.})$. No additional heat treatment was given after the surface grinding.

Test specimens were heated by resistance furnaces controlled to about $\pm 2^{\circ} \mathrm{C}$ For in-helium tests a special retort was designed incorporating a metal bellows to accommodate the cyclic strain (Figure 1). The helium environment was supplied by the Materials Test Loop (MTL) which is a recirculating system in which gaseous impurities such as $\mathrm{CO}, \mathrm{CO}_{2}, \mathrm{CH}_{4}, \mathrm{H}_{2}$ and $\mathrm{H}_{2} \mathrm{O}$ can be removed or added to maintain a specified composition of $40 \mu \mathrm{tm} . \mathrm{CO}, 10 \mu \mathrm{tm} . \mathrm{CO}_{2}, 20 \mu \mathrm{atm}$. 


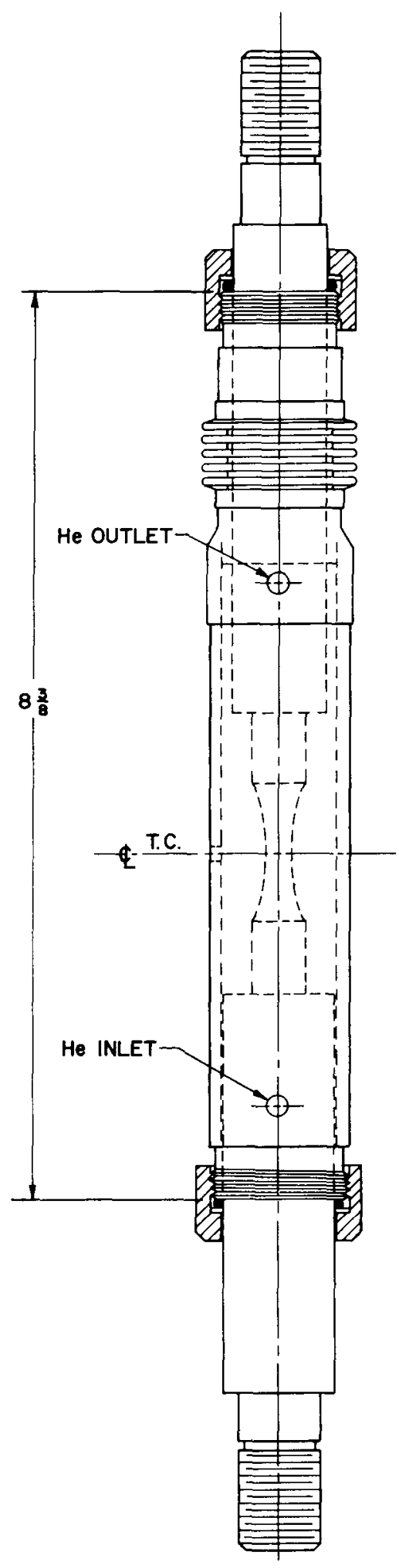

Figure 1. Test capsule for in-helium fatigue tests. 
$\mathrm{CH}_{4}, 200 \mu \mathrm{atm} . \mathrm{H}_{2}$ and $2500 \mu \mathrm{atm} . \mathrm{H}_{2} \mathrm{O}$. This represents a very "wet" system outside the range of a normal operating system. The test gas is supplied to the retort at a flow rate of 21 iters $/ \mathrm{sec}(4 \mathrm{cu}$. $\mathrm{ft} . / \mathrm{min})$ at a pressure of 1.3 atmospheres.

Pre-aging of specimens was carried out in a furnace facility which was supplied with the standard test gas from the MTL.

Post-test evaluation of fractured specimens was conducted with optical and scanning electron microscopes (SEM). The SEM was capable of X-ray elemental analyses using both the energy dispersive system (EDS) and the wavelength dispersive system (WDS).

To check surface hardness after fatigue testing, some microhardness measurements were made with a Knoop hardness tester using a 25 gm load.

\section{RESULTS}

Data obtained to date on the fatigue strength of Incoloy $800 \mathrm{H}$ in the asheat-treated condition are given in Figure 2 and Table 2 as a function of test temperature and test environment. With the exception of the $649^{\circ} \mathrm{C}\left(1200^{\circ} \mathrm{F}\right)$ curve the helium environment gives a superior strength compared to air. It should be noted, however, that the curves show non-uniform trends with respect to the two environments. At the two lower temperatures, the fatigue strengths for the shorter test times $\left(\mathrm{N}_{f} \lesssim 10^{5}\right)$ are not significantly dependent on the test environment. At longer times environmental effects became very pronounced and the air and helium test curves diverged. On the other hand, at $760^{\circ} \mathrm{C}\left(1400^{\circ} \mathrm{F}\right)$ and $871^{\circ} \mathrm{C}\left(1600^{\circ} \mathrm{F}\right)$ the environmental effect is greater at the shorter test times. For extended test periods of about 1 month ( $10^{8}$ cycles) the air and the helium test curves converge so that the effect of environment is greatly decreased. 


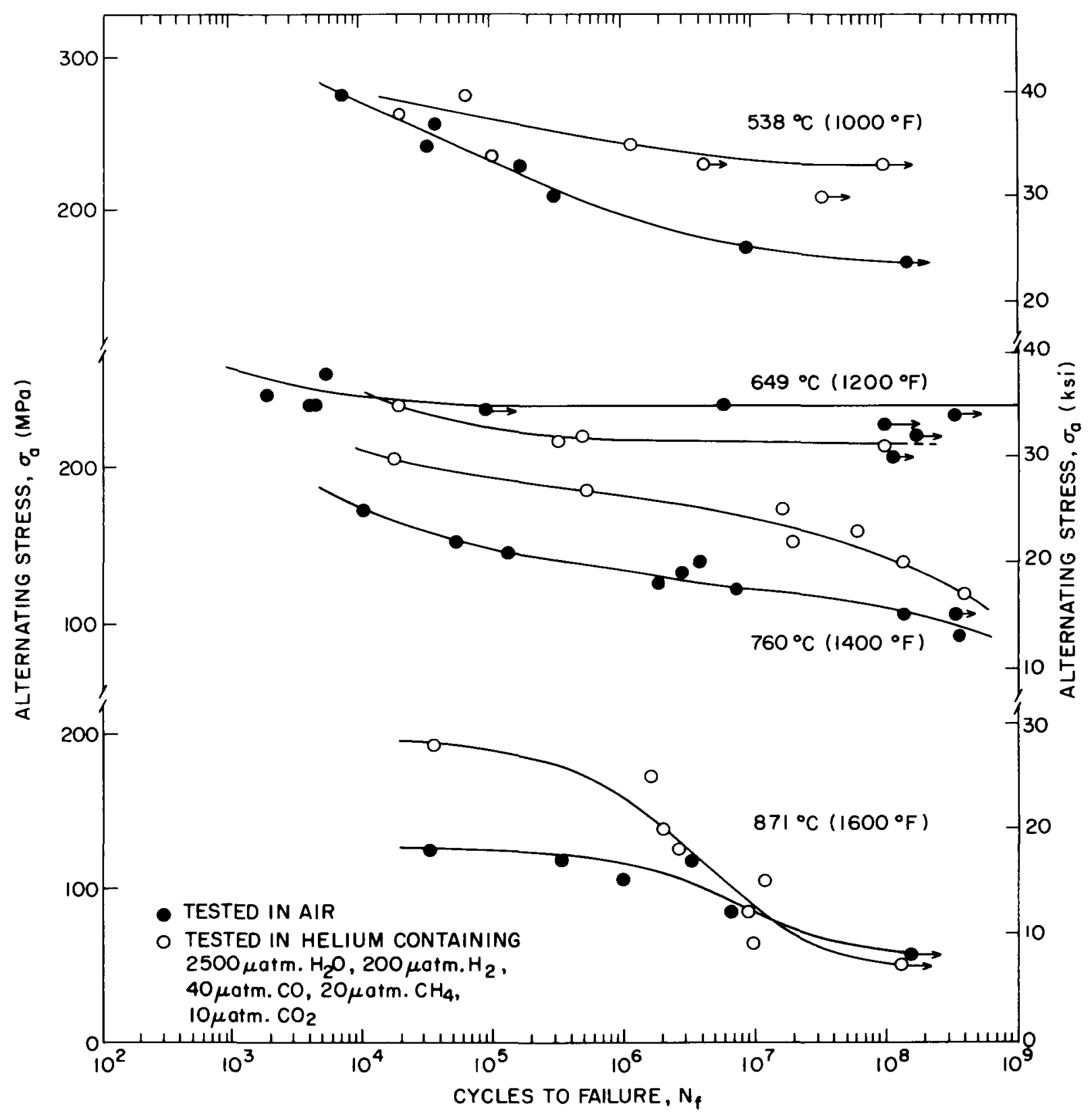

Figure 2. Effect of an HTGR helium environment on the high cycle fatigue strength of Incoloy $800 \mathrm{H}$. 
The temperature dependence of the $10^{8}$ cycle fatigue strength is shown in Figure 3 for the two test environments. In the helium environment the fatigue strengths at 538 and $649^{\circ} \mathrm{C}\left(1000\right.$ and $\left.1200^{\circ} \mathrm{F}\right)$ are similar and at temperatures greater than about $650^{\circ} \mathrm{C}\left(1200^{\circ} \mathrm{F}\right)$ the strength shows a rapid decrease. In the case of the air environment the behavior is more complicated and a peak in the fatigue strength is found at about $760^{\circ} \mathrm{C}\left(1400^{\circ} \mathrm{F}\right)$. Because of this behavior there are temperature regimes for which air testing yields lower strengths and regimes where helium testing does.

To date, the only pre-aging temperature used is $760^{\circ} \mathrm{C}\left(1400^{\circ} \mathrm{F}\right)$ and the effects of aging time on the fatigue strength are given in Figure 4 and Table 3. Pre-aging for $1500 \mathrm{~h}$ results in a 20-25 percent decrease in the fatigue strength when compared to unaged material. For aging times close to $6000 \mathrm{~h}$ much of the strength is restored to a value comparable to that for the unaged condition (Figure 5). After $10,500 \mathrm{~h}$ a small loss in strength is again not iced.

For all aging conditions there appears to be a tendency for a fatigue limit to become established in the $10^{5}-10^{7}$ cycle range (Figure 4). However, for long test times $\left(N_{f} \gtrsim 10^{7}\right.$ cycles), there is a noticeable acceleration in the rate at which the fatigue strength decreases, indicative of some form of metallurgical instability. Most of the metallurgical evaluations to date on this phenomenon have been concentrated on the $760^{\circ} \mathrm{C}\left(1400^{\circ} \mathrm{F}\right)$ and $871^{\circ} \mathrm{C}$ $\left(1600^{\circ} \mathrm{F}\right)$ test specimens, and these will be discussed separately below.

3.1 Metallurgical Evaluations on Specimens Fractured at $760^{\circ} \mathrm{C}\left(1400^{\circ} \mathrm{F}\right)$ 3.1.1 Fractography

Figure 6 shows fractographs of specimens tested in air and the helium test gas. For the in-helium tests, examples of fracture in pre-aged 


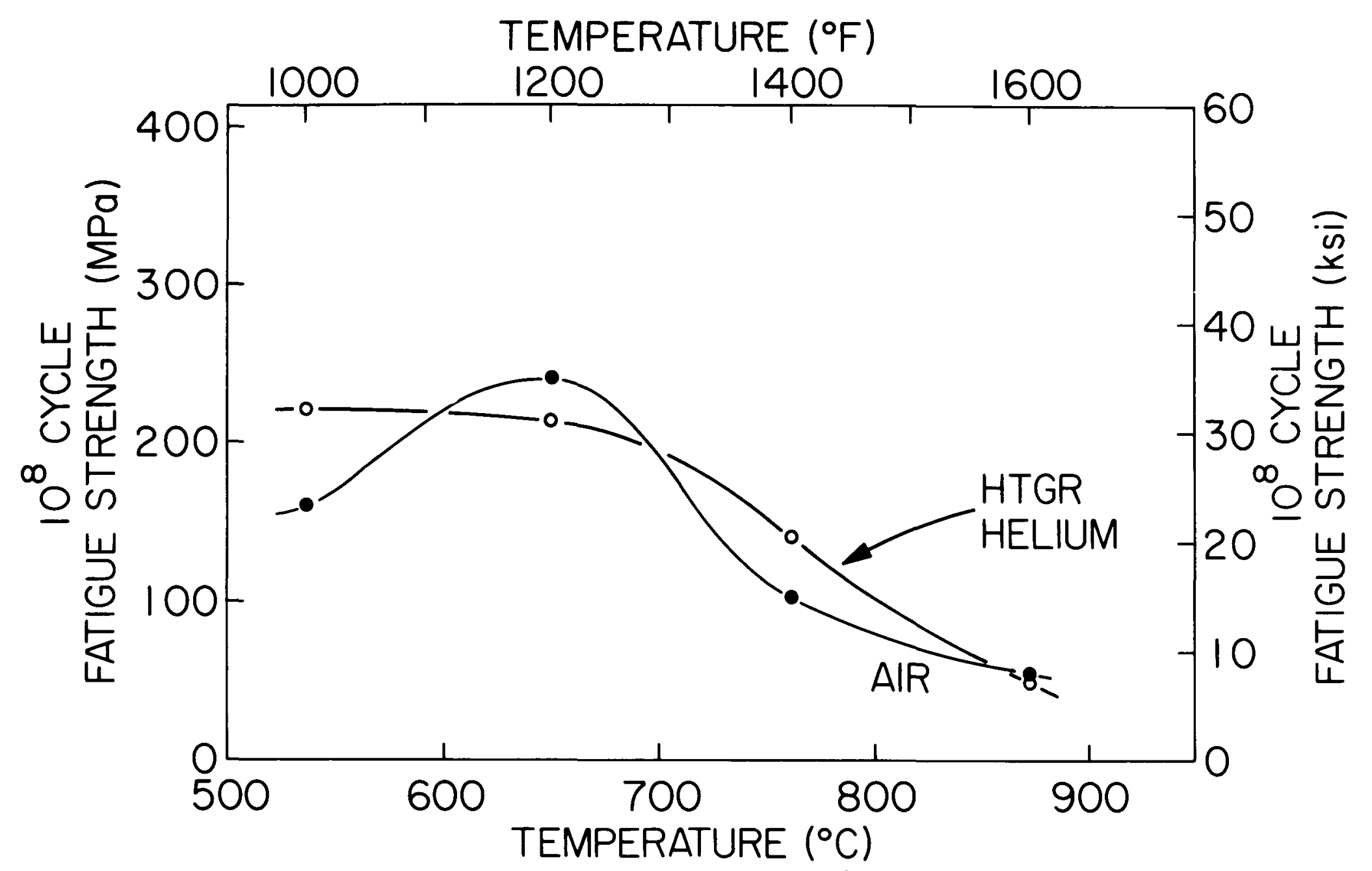

Figure 3. Temperature dependence of the $10^{8}$ cycle fatigue strength for Incoloy $800 \mathrm{H}$ as a function of test environment. 


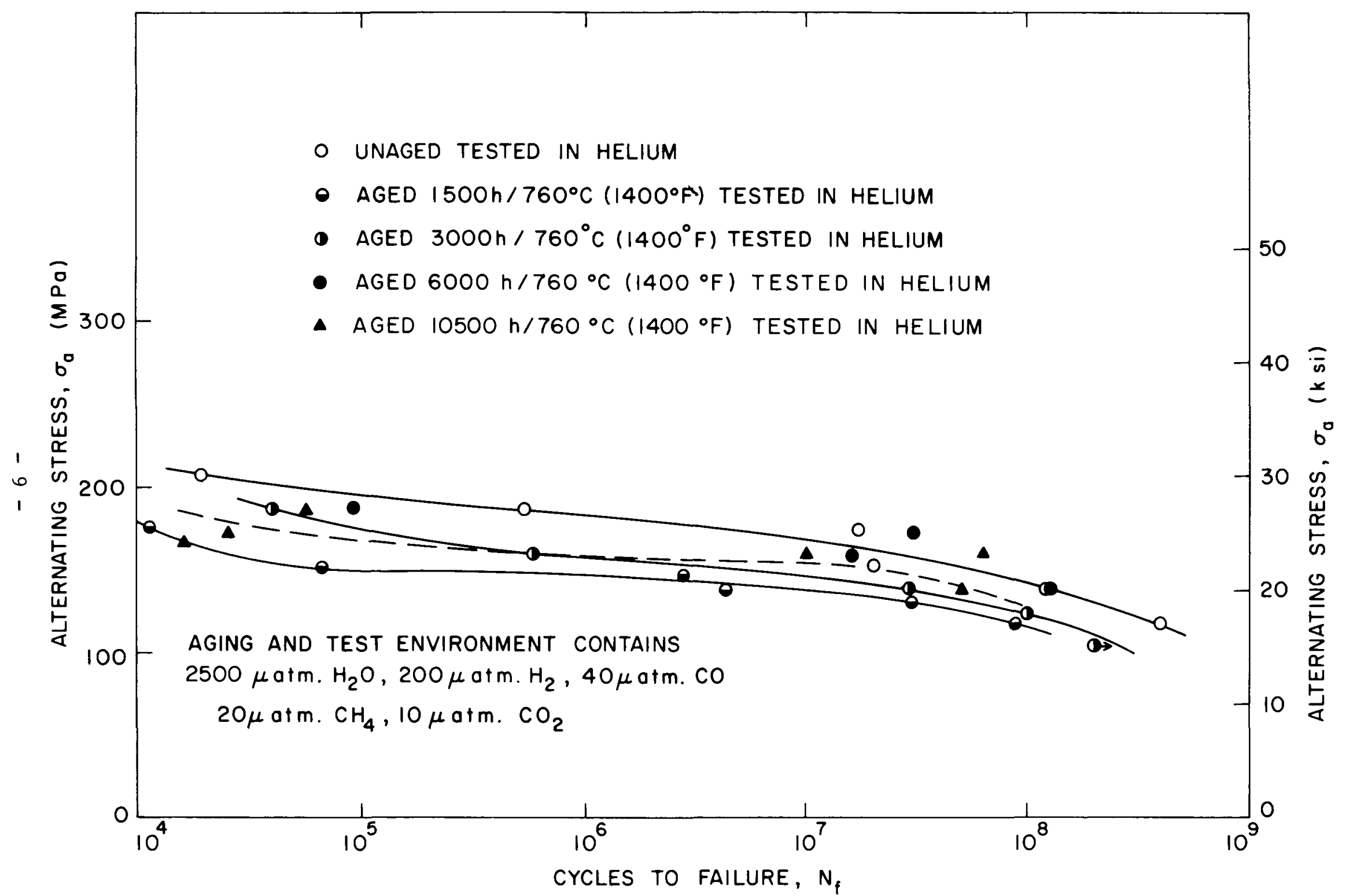

Figure 4. Effect of thermal aging in helium on the high cycle fatigue of Incoloy $800 \mathrm{H}$ at $760^{\circ} \mathrm{C}$. 


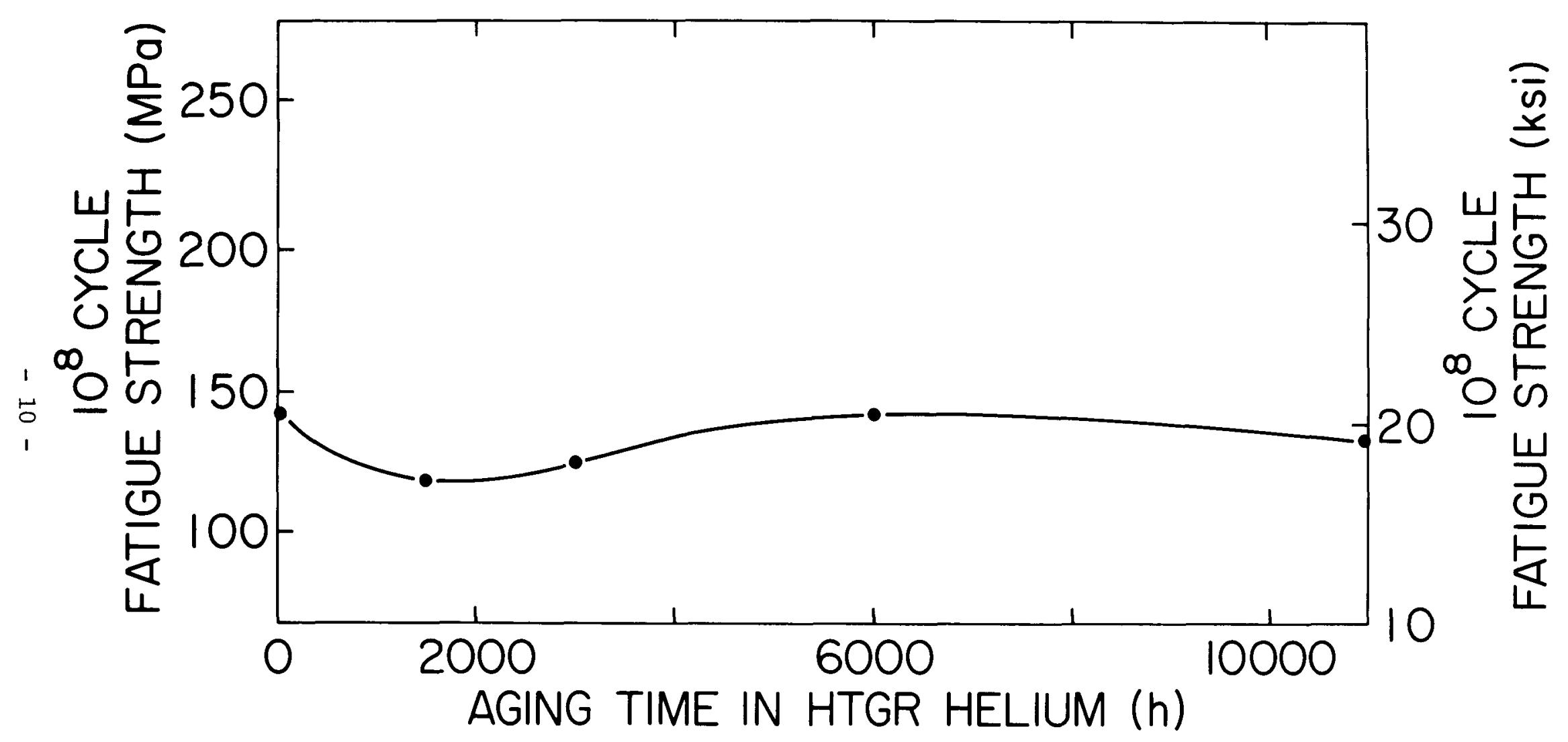

Figure 5. Effect of pretest thermal aging in HTGR helium on the $10^{8}$ cycle fatigue strength for Incoloy $800 \mathrm{H}$ at $760^{\circ} \mathrm{C}\left(1400^{\circ} \mathrm{F}\right)$. 


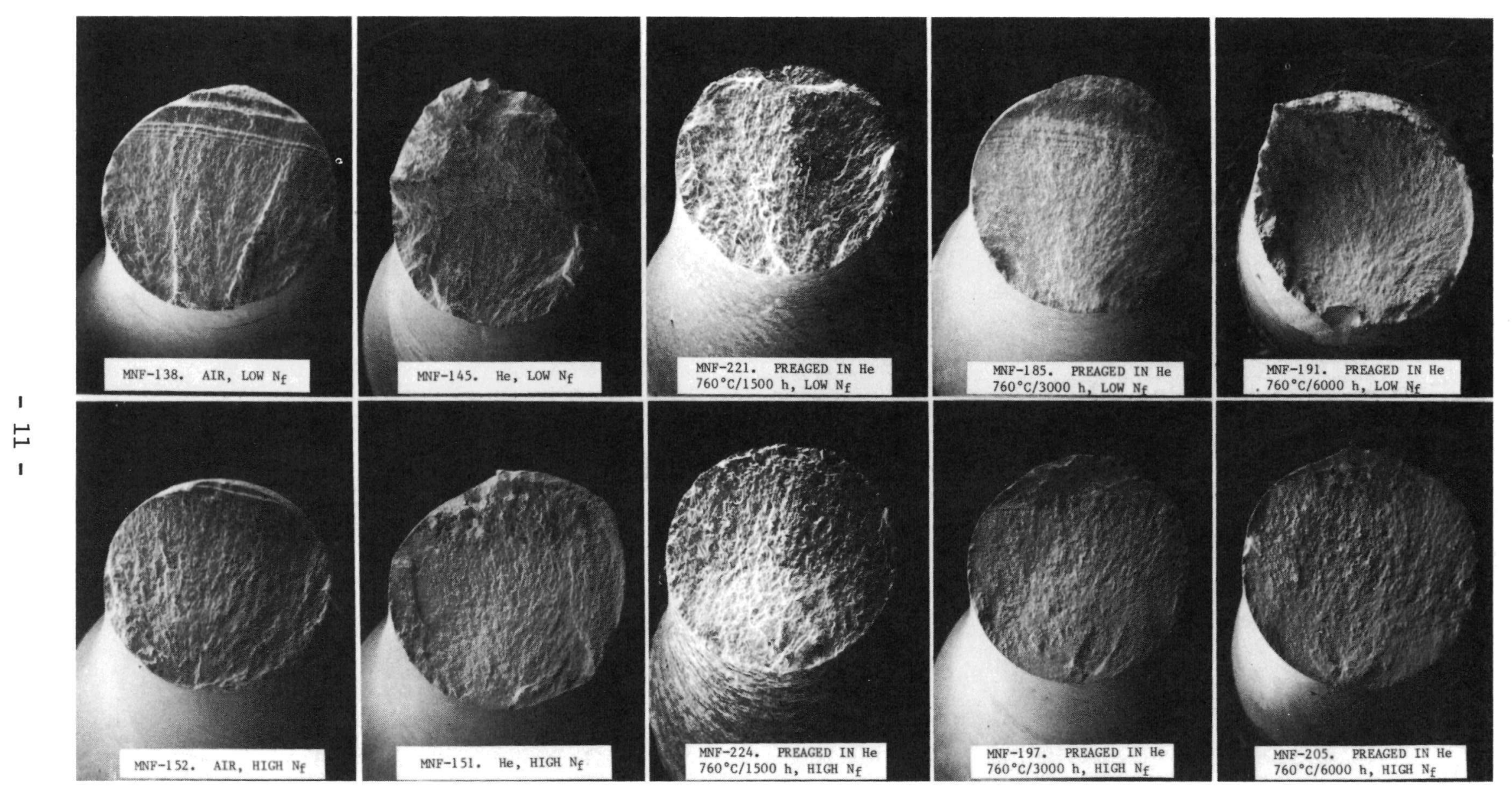

Figure 6. Fractographs of Incoloy $800 \mathrm{H}$ high cycle fatigue specimens tested at $760^{\circ} \mathrm{C}\left(1400^{\circ} \mathrm{F}\right)$ for various test environments and stress levels. Magnifications approximately $6 \mathrm{X}$. 
specimens are also given. Fractures for two stress levels were examined to determine whether this affected the mode of failure. In nearly all cases the fatigue crack propagates in a uniform manner, i.e. no large irregularities are seen in the fracture surfaces. Most often, the crack initiation zone is at the specimen surface and the crack propagates across the width of the specimen until final separation occurs along a "chisel edge". A few specimens, such as MNF-138 tested in air, showed 3 separate crack initiation points (Figure 6). In this case the cracks propagated independently until they finally linked up to form a single large crack. The separate crack propagation zones are clearly demarcated by two ridges lying parallel to the crack propagation direction. Generally, there appears to be no significant effect of stress on the fractography of Incoloy $800 \mathrm{H}$ at $760^{\circ} \mathrm{C}\left(1400^{\circ} \mathrm{F}\right)$.

A close-up view of the crack initiation zones is shown in Figure 7. There are no noticeable precipitates or metallurgical features that could be identified with the initiation points. However, there is frequently a sharp ridge associated with crack initiation lying parallel to the crack propagation direction. This is seen most distinctly in specimen MNF-152, tested in air.

Several specimens showed internal crack initiation points, an example of which is shown in Figure 8. All internal failures occurred in specimens which were pre-aged and they were more common in specimens aged for $6000 \mathrm{~h}$. Again, no metallurgical feature could be identified as the cause of crack initiation.

Figure 9 shows the nature of the external surfaces of the fatigued specimens. In the cases of the unaged specimens tested in air and in helium, the scale is very adherent and no exfoliation is seen. For the specimens aged for 1500 and $6000 \mathrm{~h}$, however, much of the scale is lost during the 


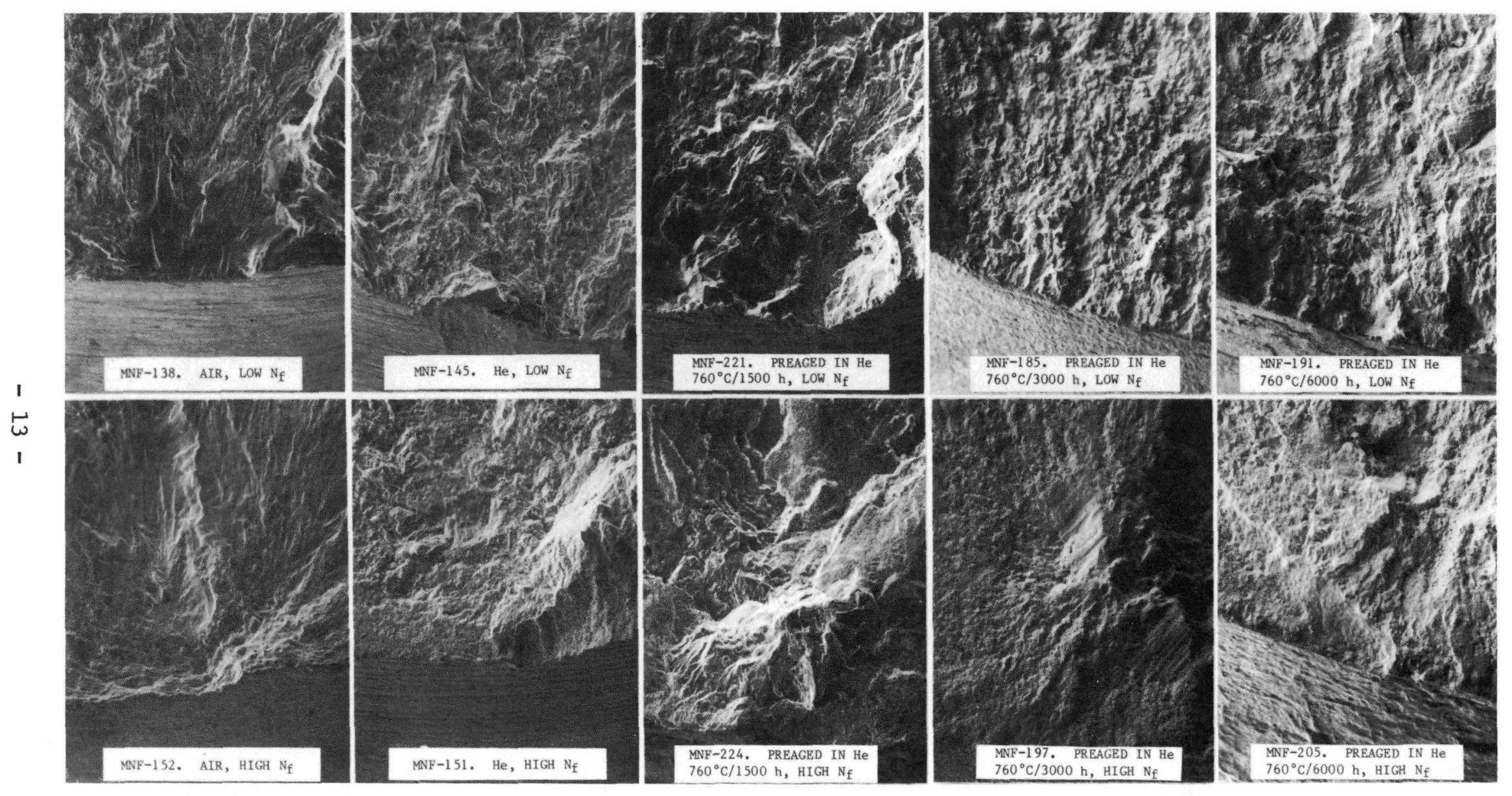

Figure 7. Crack initiation points in Incoloy $800 \mathrm{H}$ high cycle fatigue specimens tested at $760^{\circ} \mathrm{C}$ $\left(1400^{\circ} \mathrm{F}\right)$ for various test environments and stress levels. Magnifications 60X. 

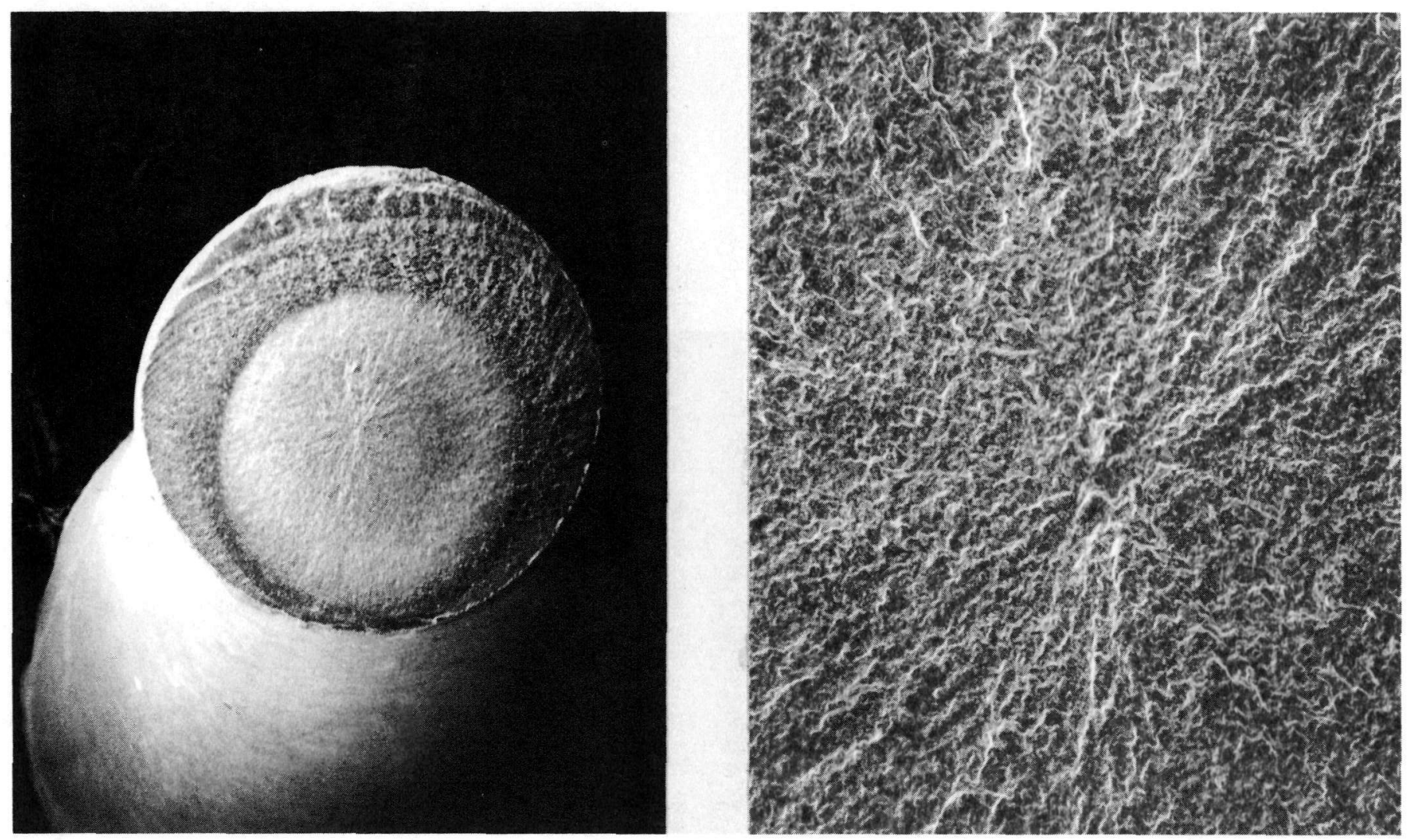

Figure 8. Internal crack initiation in an Incoloy $800 \mathrm{H}$ high cycle fatigue specimen pre-aged in $\mathrm{HTGR}$ helium for $600 \mathrm{~h} / 760^{\circ}\left(1400^{\circ} \mathrm{F}\right)$ and tested in same environment at $760^{\circ} \mathrm{C}$. Magnifications $10 \mathrm{X}$ and $100 \mathrm{X}$, respectively. 


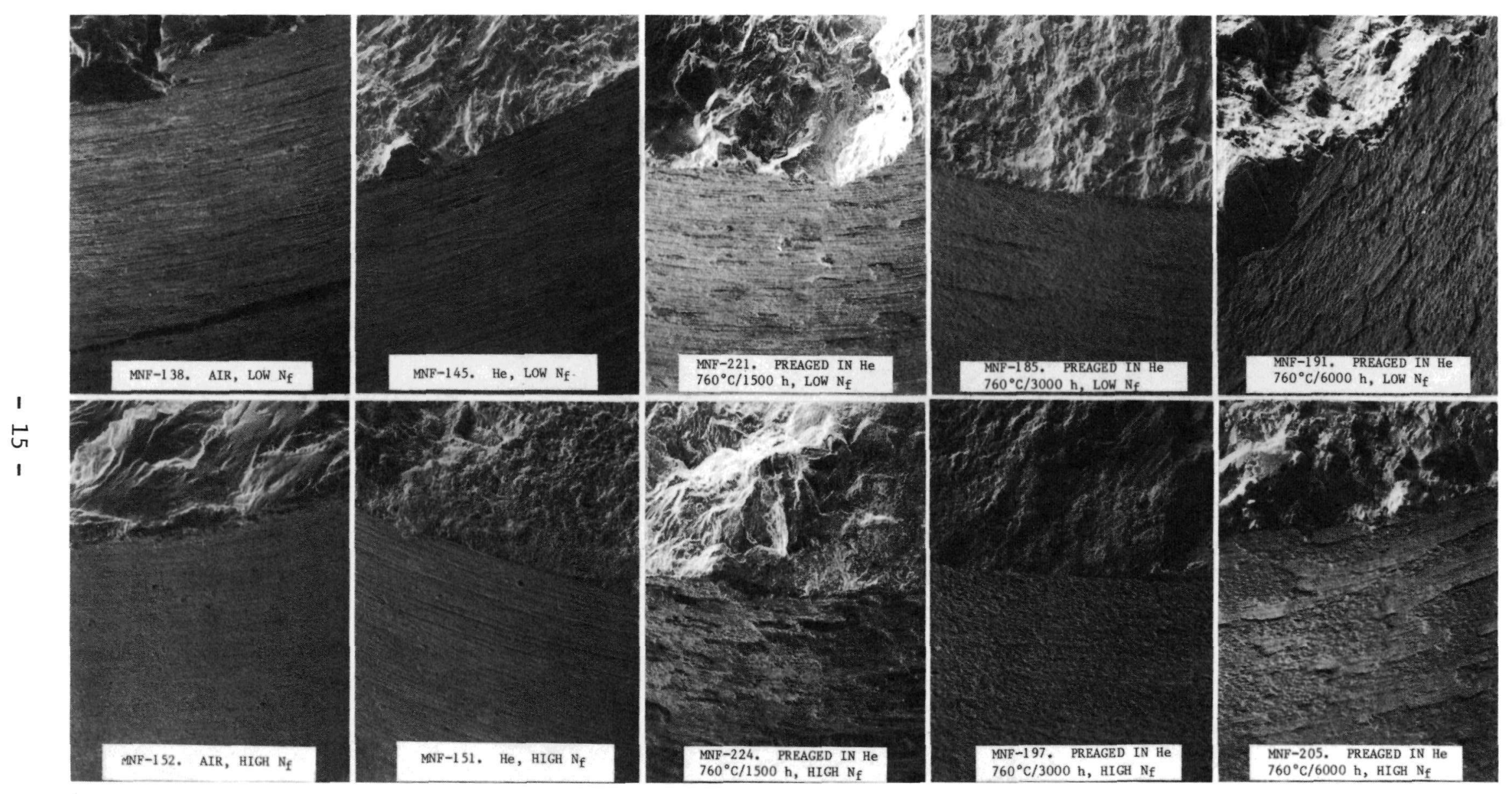

Figure 9. Surface oxidation characteristics in Incoloy $800 \mathrm{H}$ high cycle fatigue specimens tested at $760^{\circ} \mathrm{C}\left(1400^{\circ} \mathrm{F}\right)$ for various test environments and stress levels, magnifications $70 \mathrm{X}$. 
fatigue process. The $1500 \mathrm{~h}$ samples show significantly more exfoliation than the $6000 \mathrm{~h}$ specimens. In the $3000 \mathrm{~h}$ aged specimens surface oxidation is quite marked but there is no noticeable scale loss during fatigue.

Striations are commonly observed in the failed specimens, as shown in Figure 10. The locations shown are approximately at the center of the fracture surfaces. They are finely spaced and frequently quite diffuse. In most cases, secondary cracks are observable in the fracture surfaces. No consistant correlation could be obtained between the fracture surface appearance, stress level, test environment and pre-aging time. Crack propagation near the edge of the specimen is shown for a $1500 \mathrm{~h}$ aged specimen (Figure 11). Intergranular corrosion is clearly present and the fatigue crack in the surface regions of this specimen propagate intergranularly.

In regions of the fracture surface where final separation is imminent, ductile dimple formation is present (Figure 12). The dimples are the least pronounced in the specimens aged for $1500 \mathrm{~h}$ and indicate that more brittle crack propagation persists up to final failure. No significant effect of stress level is noticed in these data.

An interesting observation for nearly all specimens examined with the scanning electron microscope is the presence of small dense clusters of particles - see Figure 13. In certain cases, such as specimen MNF-224, small whiskers are also seen. Generally, specimens tested for longer times (high $N_{f}$ ) display larger more closely packed particles. Owing to the small particle sizes and irregular shapes it was difficult to quantitatively determine their chemical nature using the scanning electron microscope/microprobe. Most probably the particles are oxides formed on the fractured surfaces from interaction with the test gases. 


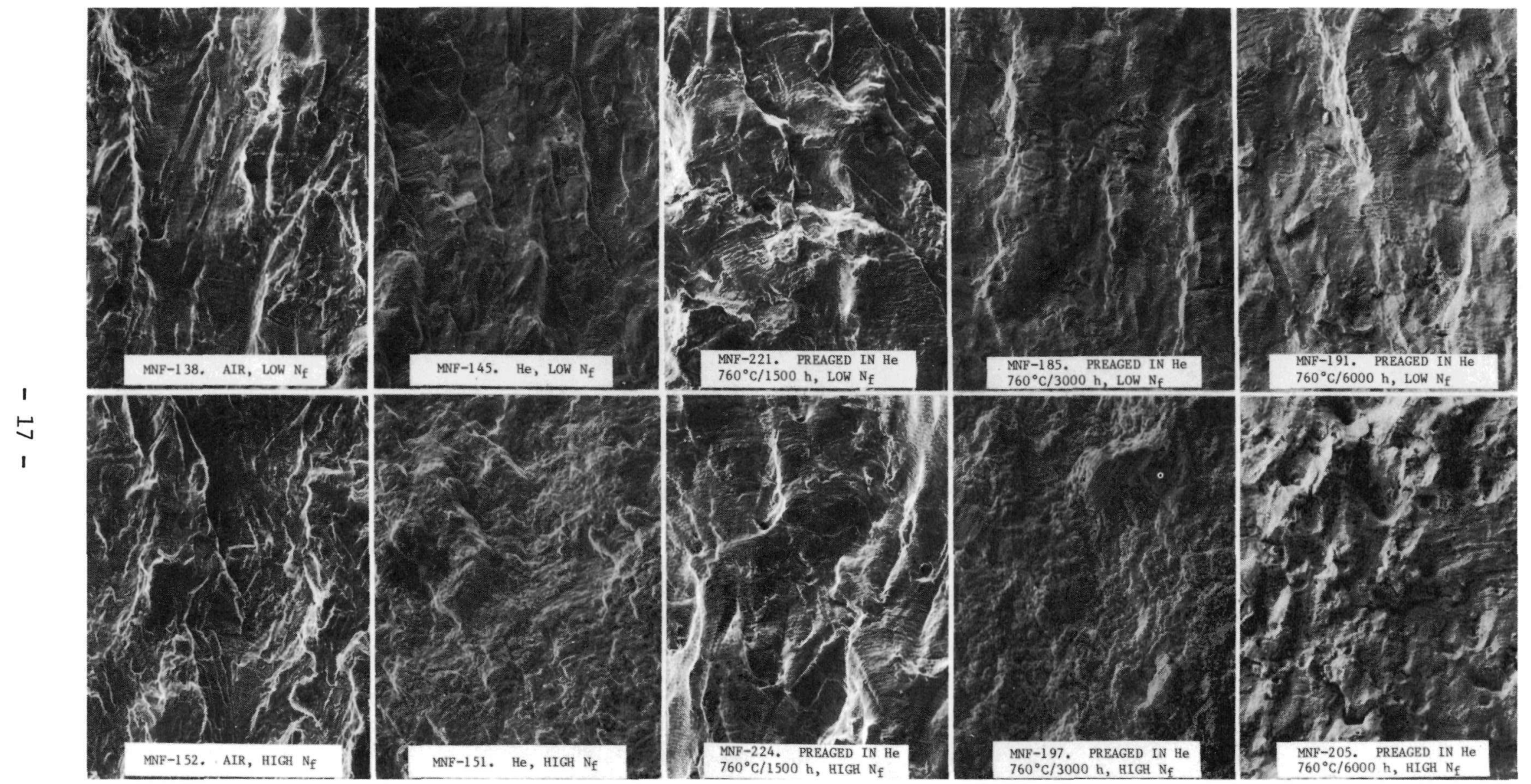

Figure 10. Striations in Incoloy $800 \mathrm{H}$ high cycle fatigue specimens tested at $760^{\circ} \mathrm{C}\left(1400^{\circ} \mathrm{F}\right)$ for various test environments and stress levels. Magnifications 150X. 

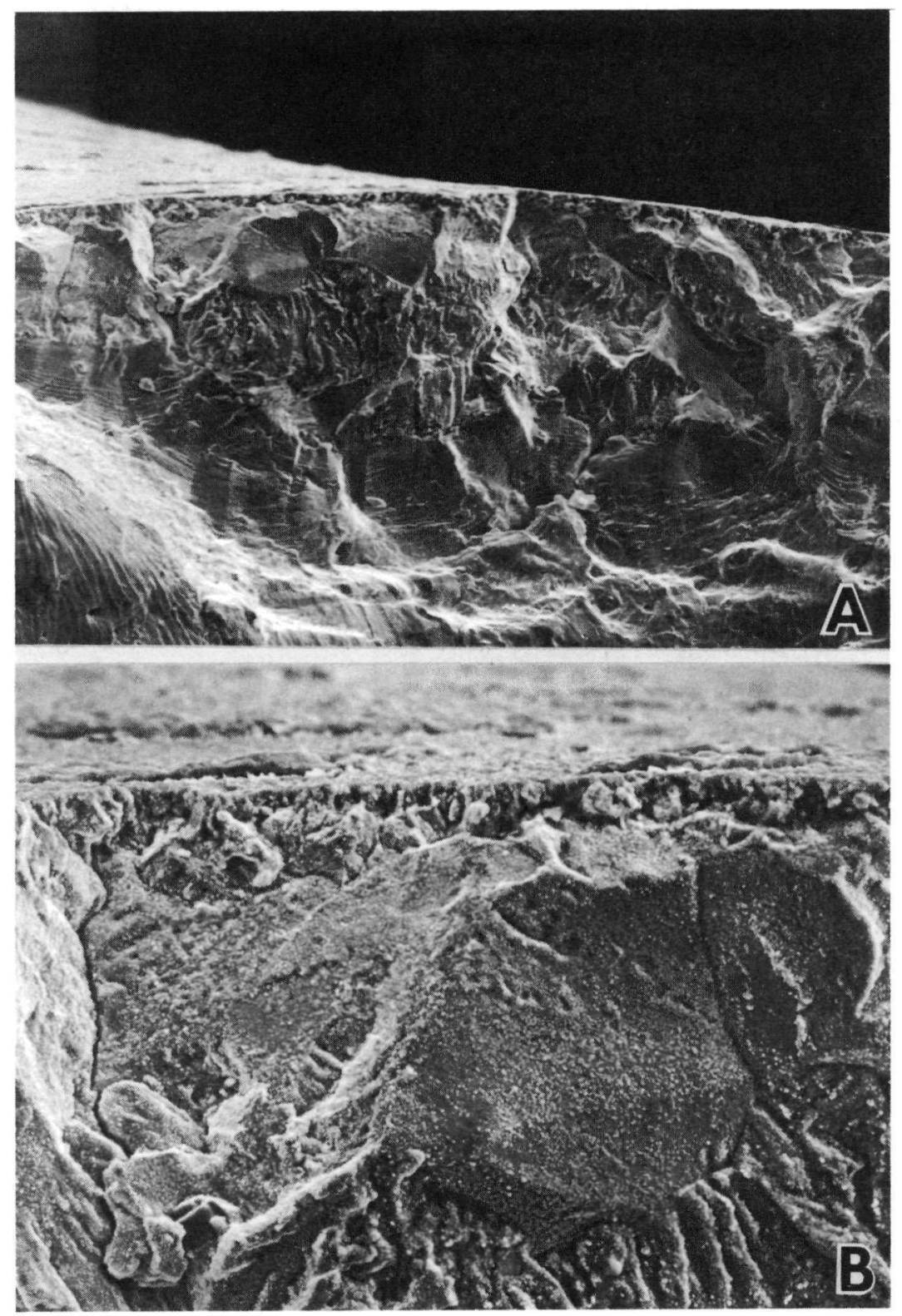

Figure 11. Appearances of edges of fracture surfaces in an Incoloy $800 \mathrm{H}$ high cycle fatigue specimen (MNF-221) pre-aged in HTGR helium for $1500 \mathrm{~h} / 760^{\circ} \mathrm{C}\left(1400^{\circ} \mathrm{F}\right)$ and tested in same environment; (A) Magnification 240X, (B) Magnification 600X. 


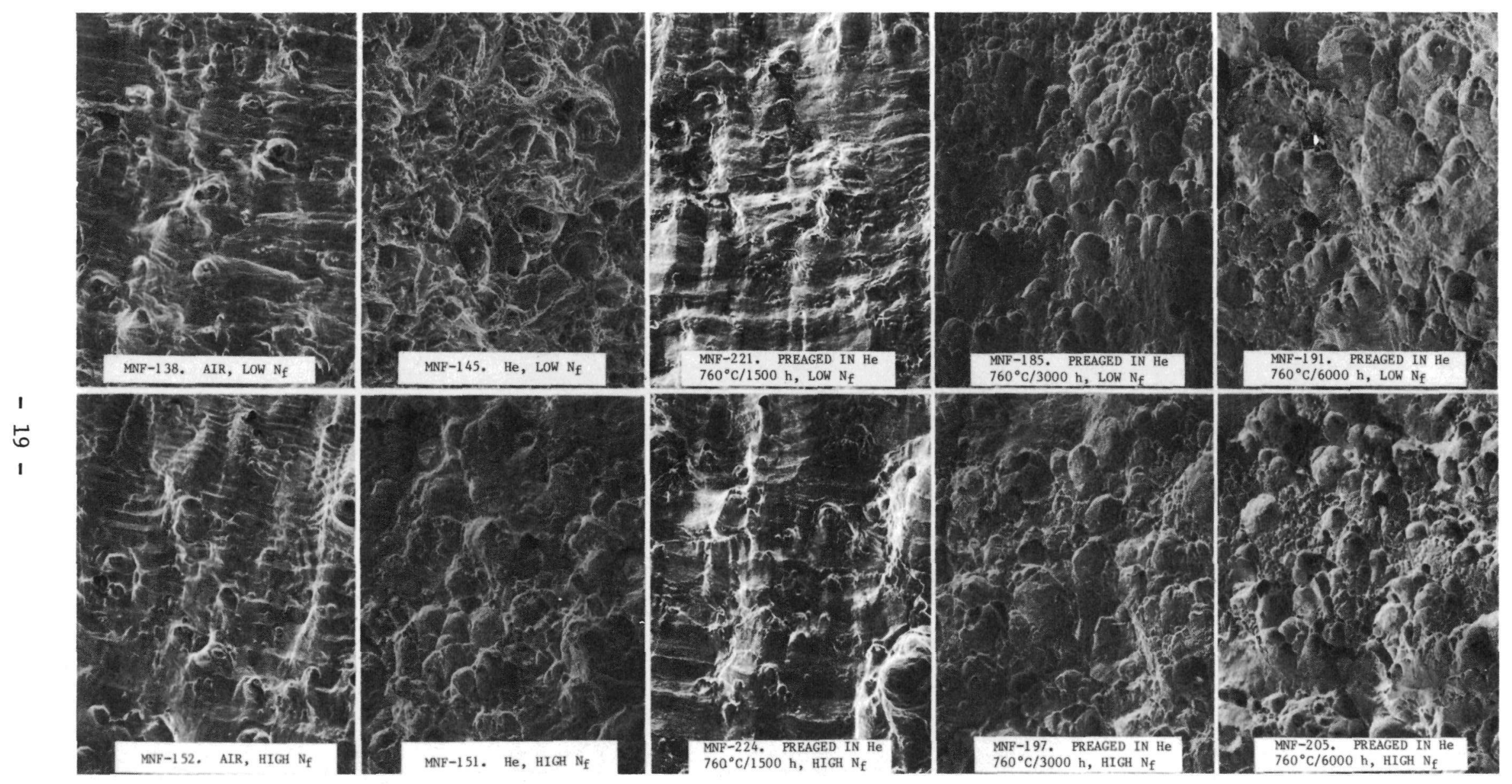

Figure 12. Stage III dimple formation in Incoloy $800 \mathrm{H}$ high cycle fatigue specimens tested at $760^{\circ} \mathrm{C}$ $\left(1400^{\circ} \mathrm{F}\right)$ for various test environments and stress levels. Magnification 150X. 

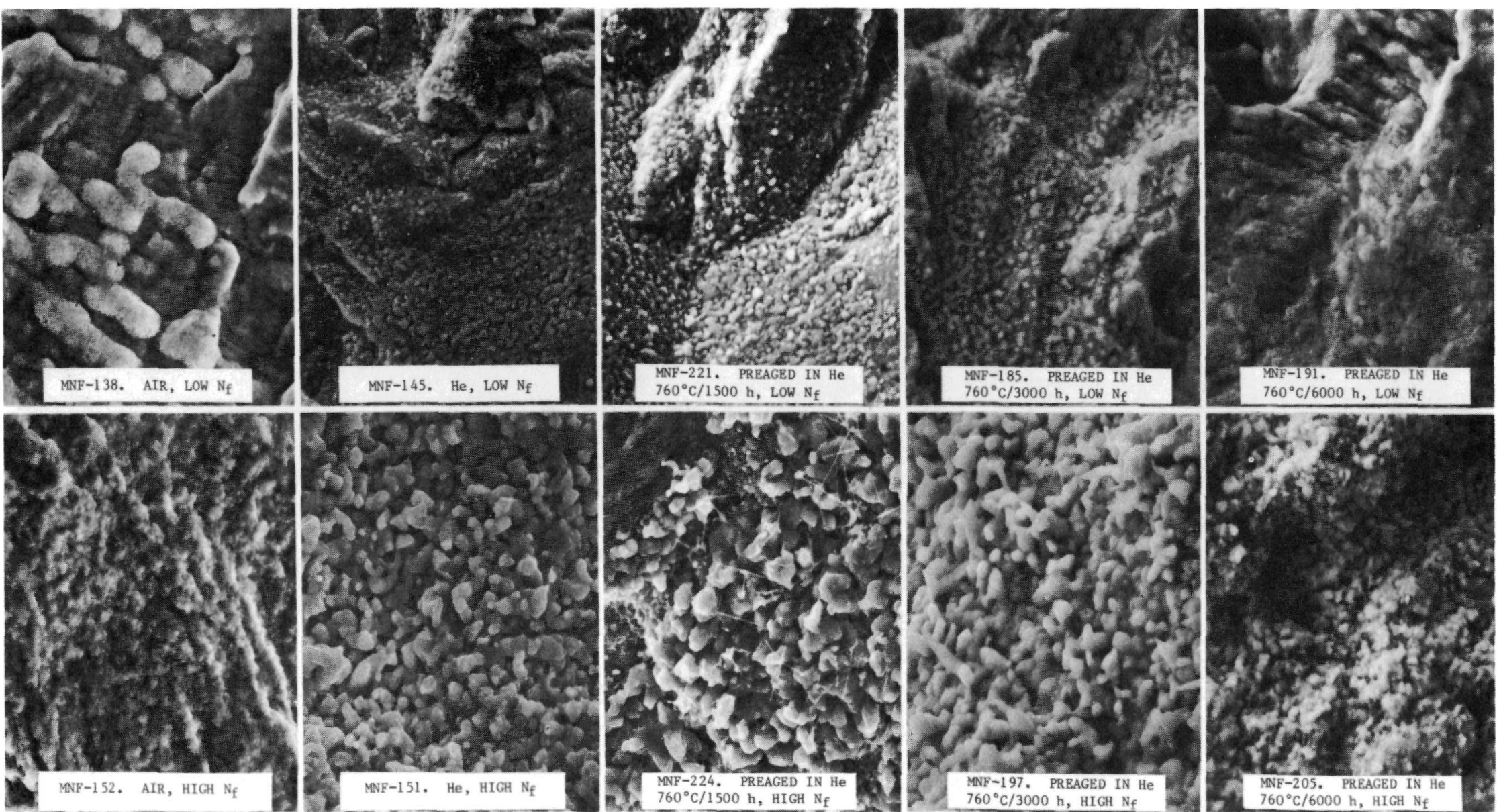

$60^{\circ} \mathrm{C} / 6000 \mathrm{~h}$, LOW N

Figure 13. Oxidation products in fraction surfaces of Incoloy $800 \mathrm{H}$ high cycle fatigue specimens tested at $760^{\circ} \mathrm{C}\left(1400^{\circ} \mathrm{F}\right)$ for various test environments and stress levels. Magnifications $1400 x$. 


\subsubsection{Optical Microscopy}

In order to ascertain the influence of surface condition on the fracture process, a large number of failed specimens were sectioned longitudinally and examined with an optical microscope. The micrographs, shown in Figure 14, were taken from locations close to the fracture zone. The following conclusions may be drawn from these data:

- For unaged specimens tested in air and helium at $760^{\circ} \mathrm{C}$ $\left(1400^{\circ} \mathrm{F}\right)$, short-term testing $\left(\mathrm{N}_{f} \simeq 10^{4}-10^{5}\right)$ does not cause recrystallization of the cold worked surface layer introduced by surface grinding of the specimen during fabrication.

- For test times of about 1 month $\left(\sim 10^{8}\right.$ cycles) at $760^{\circ} \mathrm{C}$ $\left(1400^{\circ} \mathrm{F}\right)$ the cold worked layer is removed by recrystallization and numerous small surface cracks are formed, probably along the boundaries of the small recrystallized grains.

- For a pretest aging time of $1500 \mathrm{~h}$, two very important features are noticed. The aging has created a specific metallurgical condition in which deep intergranular attack occurs during fatigue. The fatigue cracks, although initially intergranular, can become transgranular as they grow in size. Many of the small surface grains also appear to be susceptible to intergranular cracking. The second observation is the appearance of localized areas in which deep corrosion zones are found. These are shown as dark areas in specimen MNF-224. 

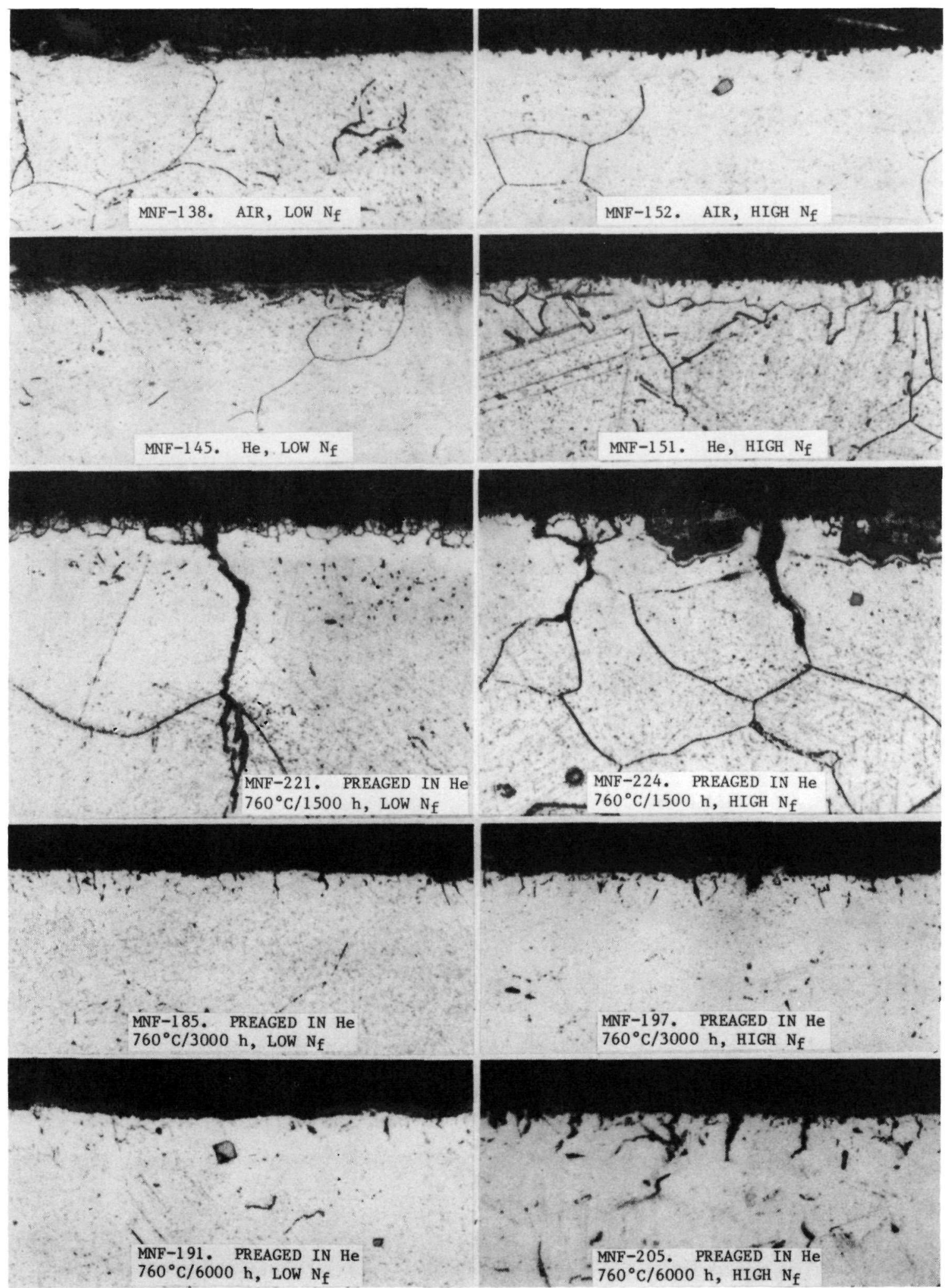

Figure 14. Recrystallization and cracking in Incoloy $800 \mathrm{H}$ high cycle fatigue specimens for various test environments and stress leve1s. Magnifications 350x. 
- For pretest aging times of 3000 and $6000 \mathrm{~h}$, surface recrystallization occurs during the aging treatment. Surface cracks are far more shallow than for the $1500 \mathrm{~h}$ aged specimens, but they are deeper in the high $N_{f}$ specimens. This is to be expected from the higher number of fatigue cycles and the significantly longer period of in-test oxidation.

\subsubsection{Scanning Electron Microscope/Microprobe Analyses}

The nature of the oxidized surfaces was also investigated with the scanning electron microscope/microprobe as shown in Figure 15 . The recrystallized surface layers are clearly observable in the unaged specimens which were tested in air and in helium. For the air test specimen (MNF-152) the surface scale is principally a $\mathrm{Cr} / \mathrm{Mn}$ oxide, with the manganese oxide being closer to the surface. This is in agreement with previously reported work. $6,12,13$ For the unaged specimen tested in helium (MNF-151) the $\mathrm{Cr} / \mathrm{Mn}$ oxide is still present but significant quantities of iron, nickel and titanium are also observed, possibly as oxides. In a sample pre-aged for $1500 \mathrm{~h}$, prior to testing in helium, the oxide scale is more complex. The $\mathrm{Cr} / \mathrm{Mn}$ oxide layer has spalled off during test (Figure 9) and an iron oxide layer has formed on the newly exposed surface. No chromium oxide is formed here since the original $\mathrm{Cr} / \mathrm{Mn}$ oxide creates a chromium depleted region. However, chromium oxide does form at depths below the chromium depleted zone.

To confirm that the unusual oxidation behavior for the $1500 \mathrm{~h}$ pre-aged specimen is a result of stress induced scale exfoliation, scanning electron microscope/microprobe X-ray line scans were performed on the same sample shown in Figure 15 but in a region where the stress level was only 25 percent of the value at the location shown in Figure 15 . The data, given in 

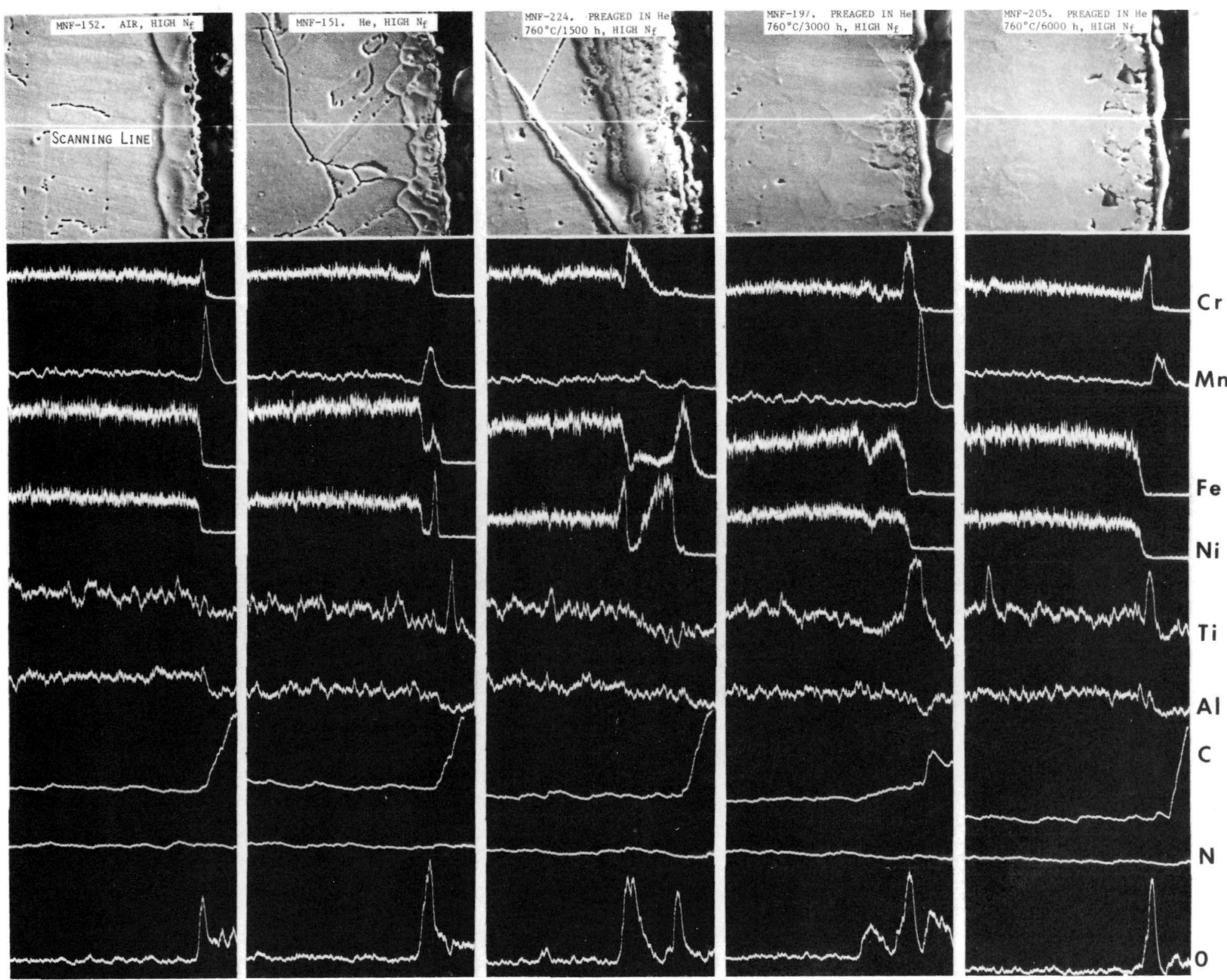

Figure 15. Scanning electron microscope/microprobe scans through the surfaces of Incoloy $800 \mathrm{H}$ high cycle fatigue specimens as a function of test environment and pretest thermal aging time. Aging and test temperature was $760^{\circ} \mathrm{C}\left(1400^{\circ} \mathrm{F}\right)$. Magnifications $425 \mathrm{X}$. 
Figure 16, show that in this low stress region the corrosion zone thickness is greatly reduced. It also consists of the usual $\mathrm{Cr} / \mathrm{Mn}$ oxides with small amounts of titanium and aluminum present. In fact, the oxidation process is basically quite similar to that for the 3000 and $6000 \mathrm{~h}$ aged specimens (Figure 15). It is, therefore, clear that the abnormal oxidation behavior for the $1500 \mathrm{~h}$ aged specimen, shown in Figure 15, is a direct result of stress induced oxide scale exfoliation during test. Apparently, for aging times of 3000 and $6000 \mathrm{~h}$, the $\mathrm{Cr} / \mathrm{Mn}$ oxide scale becomes more adherent and fatigue cycling is less likely to dislodge it.

The carbon and nitrogen levels, shown in Figure 15, do not change within the sensitivity of the scanning electron microscope/microprobe readings. The observed large increase in the carbon content in the scans is caused by the plastic compound in which the specimens are mounted.

\subsubsection{Microhardness Evaluations}

Since fatigue is usually a surface initiated failure mechanism, any metallurgical changes in the surface of a fatigue specimen, either during pretest thermal aging or during in-test cyclic stressing, could cause changes in fatigue resistance. This is especially important in reactor components which are often placed into service with surfaces which are in a plastically deformed state because of fabrication procedures such as grinding or machining. Since the current specimens were surface ground to shape after heat treatment, the nature of surface changes may be investigated conveniently by carrying out microhardness traverses across specimens which had been sectioned after fracture. By selecting specimens which had been pre-aged for varying times and temperatures, and specimens which had been tested for various lengths of time, it was hoped that some insight could be gained regarding 


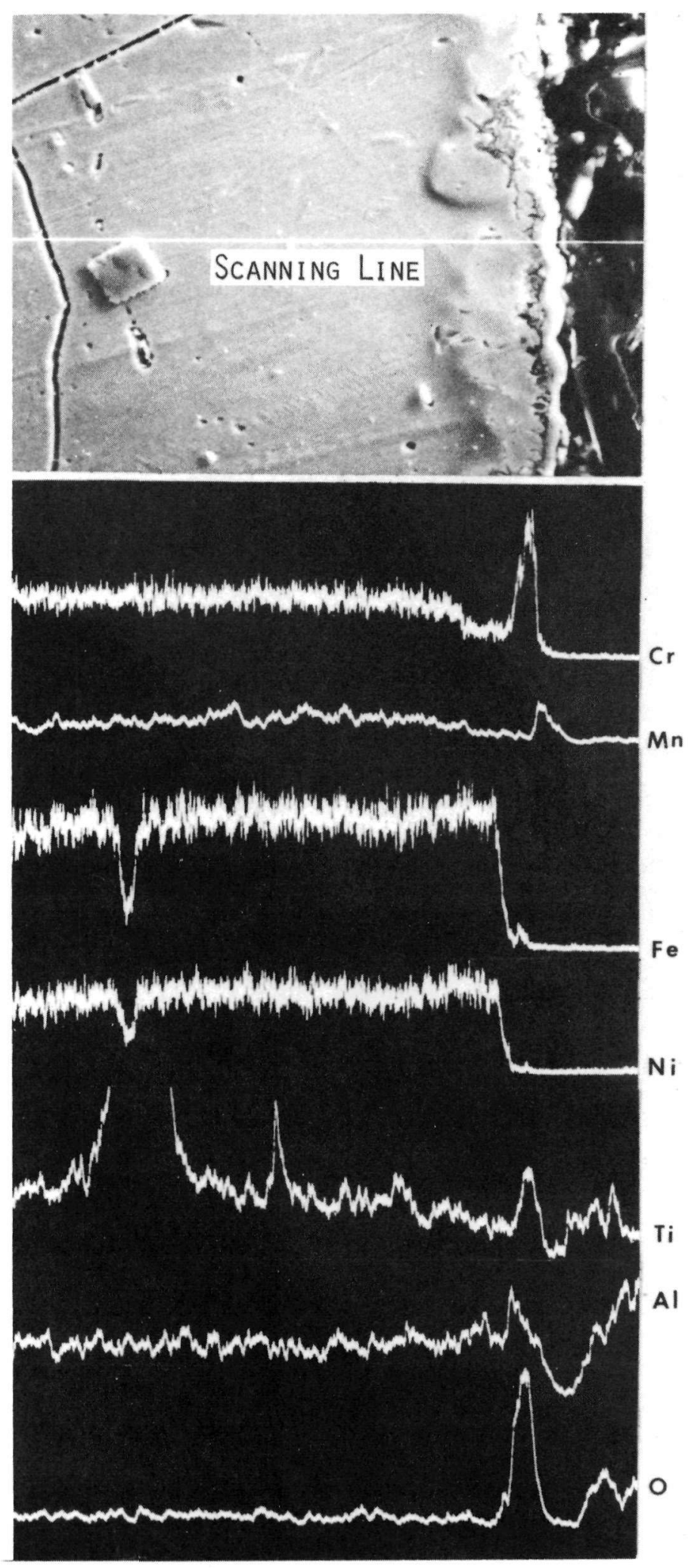

Figure 16. Scanning electron microscope/ microprobe scans through the surface of Incoloy $800 \mathrm{H}$ specimen after exposure to HTGR hel ium environment at $760^{\circ} \mathrm{C}$ $\left(1400^{\circ} \mathrm{F}\right)$ for $1500 \mathrm{~h}$. Magnifications $800 \mathrm{X}$. 
the interaction between aging time, aging temperature, recrystallization of the cold worked surface layer, and the fatigue life. Figure 17 shows a typical microhardness traverse. Average microhardness changes were obtained by carrying out several traverses in regions close to the fracture surface where the applied stress is accurately known. Sufficient traverses were made until the hardness trends were established with confidence. Figure 18 gives typical data for several specimens which were tested for relatively short times ( $N$ $\left.5.5 \times 10^{5}\right)$. These values should be compared with a bulk hardness value of about $70 \mathrm{~kg} / \mathrm{mm}^{2}$ for as-heat-treated material. All of the unaged specimens tested at 649 and $760^{\circ} \mathrm{C}\left(1200\right.$ and $\left.1400^{\circ} \mathrm{F}\right)$ show significantly higher hardness values adjacent to the surface indicating that the cold worked layer is still intact. The bulk hardness values for the samples were obtained by averaging at least 6 values obtained in regions of the samples remote from the surface where oxidation and cold work/recrystallization phenomenon could be present.

For samples pre-aged for 1500,3000 and $6000 \mathrm{~h}$ significant changes in behavior were noticed. Recrystallization of the work hardened surface occurred and softening was detected. In addition, the bulk microhardness decreased and it was especially pronounced in the specimen aged for $1500 \mathrm{~h}$. Figure 19 gives a complete summary of microhardness profiles obtained as a function of test environment, test temperature, pretest aging treatment and test duration $\left(N_{f}\right)$. The principal conclusions that can be drawn from these data are:

- For unaged Incoloy $800 \mathrm{H}$ tested in air at $649^{\circ} \mathrm{C}\left(1200^{\circ} \mathrm{F}\right)$ the surface is significantly harder than for the bulk. For the longer test times the hardness gradient is decreased and there is also a significant decrease in bulk hardness. 


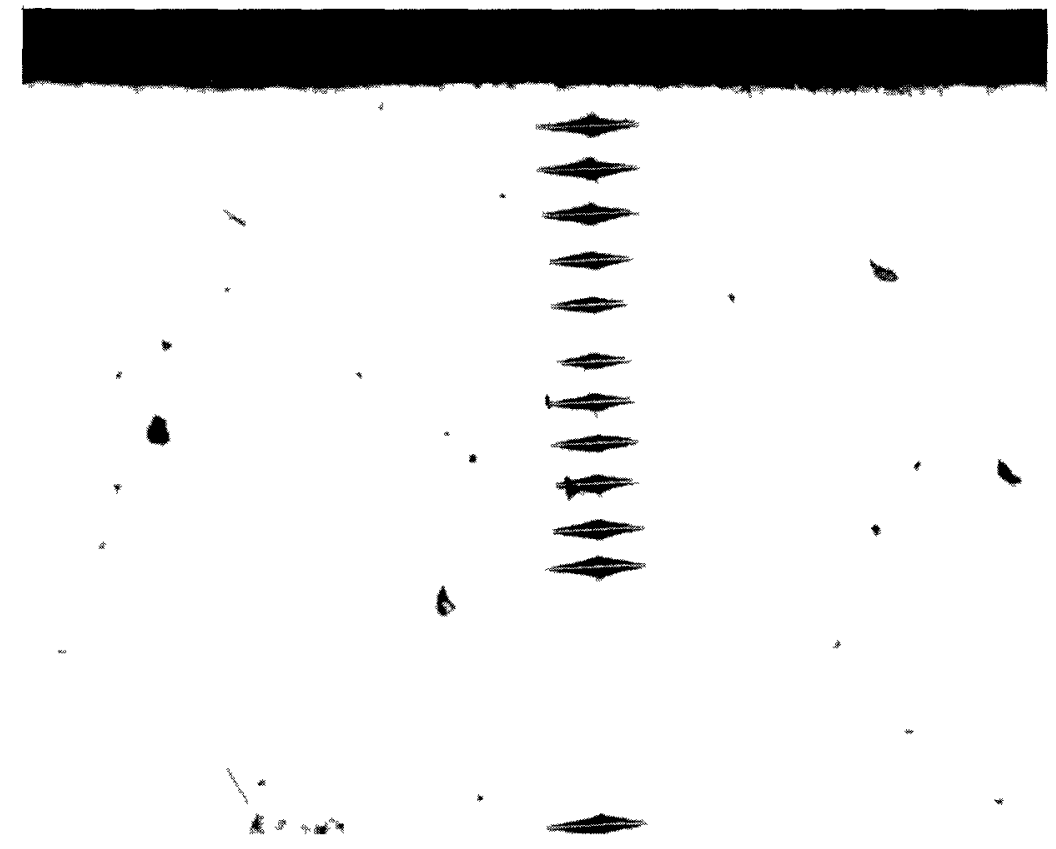

Figure 17. Knoop microhardness traverses in a sectioned Incoloy $800 \mathrm{H}$ high cycle fatigue specimen tested at $649^{\circ} \mathrm{C}$ $\left(1200^{\circ} \mathrm{F}\right)$ in air; specimen MNF-164. Magnification 250X.

- For unaged specimens tested in helium at $649^{\circ} \mathrm{C}\left(1200^{\circ} \mathrm{F}\right)$ there appears to be a greater tendency towards surface recrystallization and softening when compared to testing in air at the same temperature.

- For unaged material tested in air and helium at $760^{\circ} \mathrm{C}$ $\left(1400^{\circ} \mathrm{F}\right)$ there is no surface recrystallization for short term tests. For longer test times complete recrystallization of the deformed surface layer occurs, but there does not appear to be a tendency for general bulk softening.

- For specimens pre-aged for $1500 \mathrm{~h}$ at $760^{\circ} \mathrm{C}\left(1400^{\circ} \mathrm{F}\right)$ the pre-aging is apparently responsible for surface recrystallization and bulk softening. This may be inferred since 


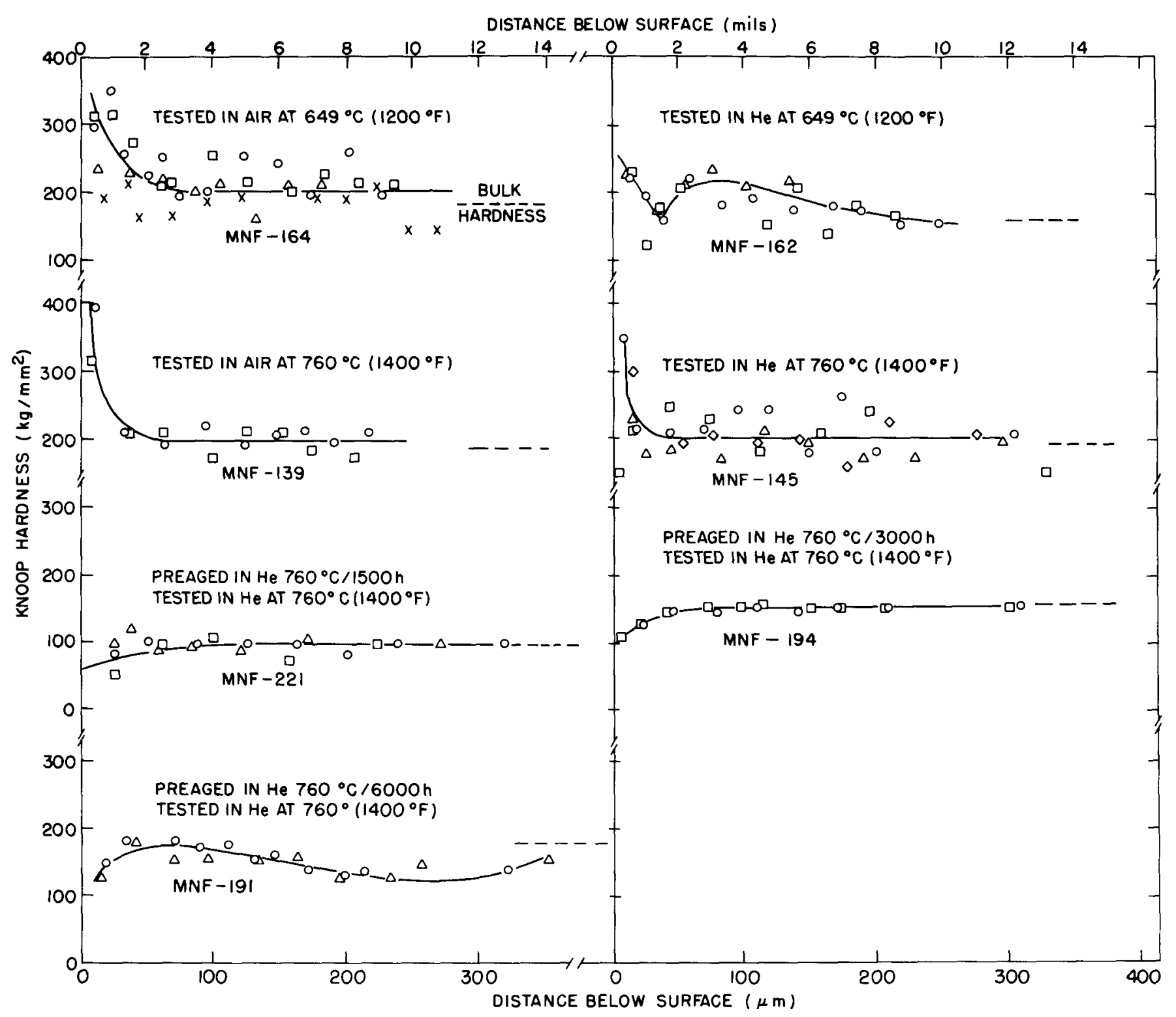

Figure 18. Surface microhardness profiles for Incoloy $800 \mathrm{H}$ fatigue specimens as a function of test temperature, test environment and therma 1 pre-aging time. 
TEST TIME ( $h$ )

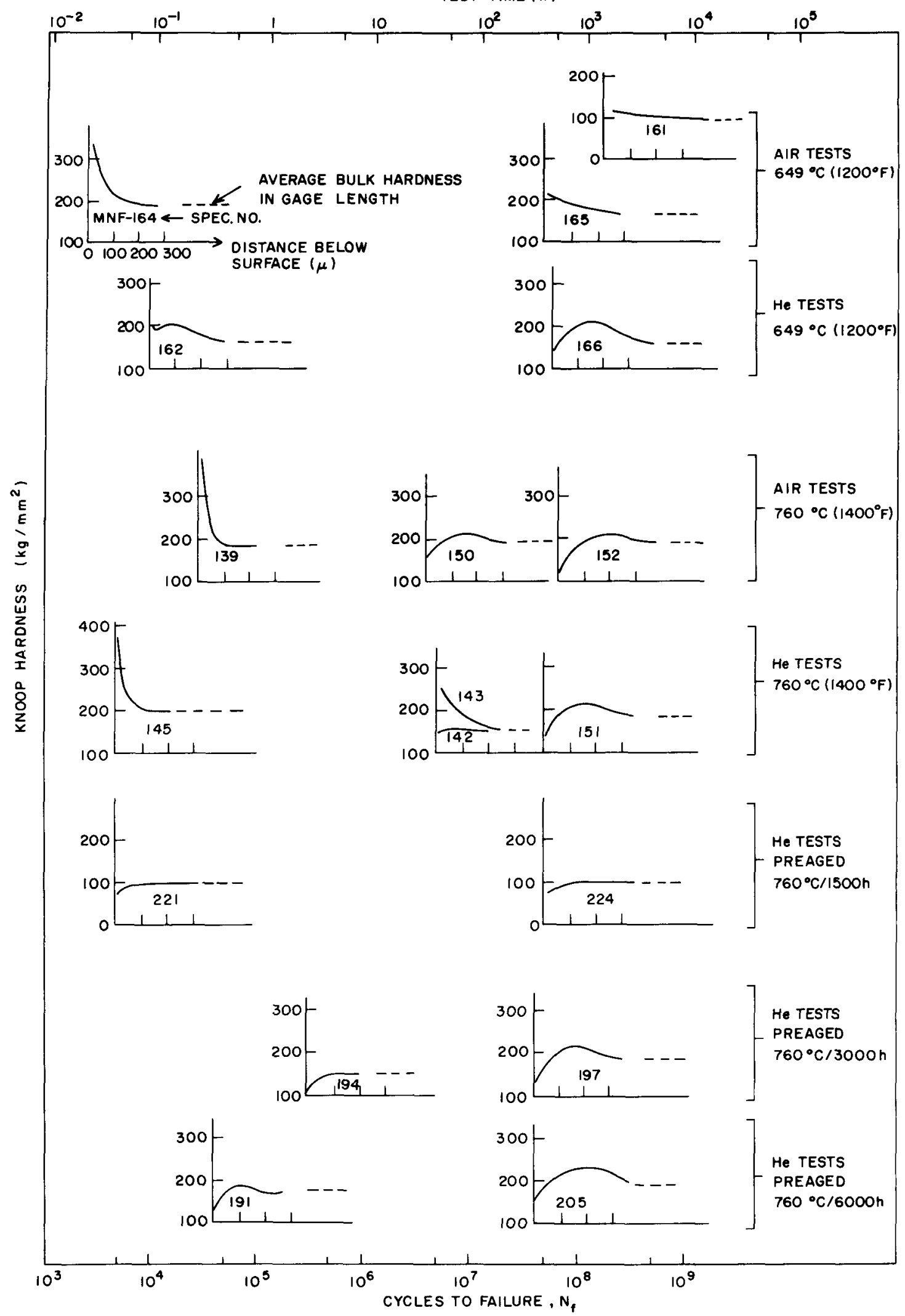

Figure 19. Schematic of surface hardness profiles for Incoloy $800 \mathrm{H}$ fatigue specimens as a function of test temperature, test environment and thermal pre-aging condition. 
these two effects are present in specimen MNF-221 which fractured in a very short time after test initiation.

- For longer pre-aging times of 3000 and $6000 \mathrm{~h}$, surface recrystallization also occurs during pre-aging. However, for the longer test times $\left(\mathrm{N}_{f} \sim 10^{8}\right)$ the bulk hardness increased to a Knoop hardness value of about $175 \mathrm{~kg} / \mathrm{mm}^{2}$.

Since bulk hardness changes may be induced by both cyclic stressing and thermal aging, an attempt was made to separate the two effects in the current fatigue specimens. This was achieved by determining the bulk hardness of a failed specimen in the minimum diameter region, which is the high stress area, and in a region near the specimen shank where the stress level is about 25 percent of this value. Since both areas experienced the same pretest and in-test thermal history, any differences in hardness are attributable to cyclic deformation. Figure 20 shows the results obtained. For the low stress region in which the material is not subjected to cyclic hardening, the thermally induced increase in hardness does not become significant until the aging time exceeds about $1500 \mathrm{~h}$. The hardness then abruptly increases, and a knoop hardness value of approximately $160 \mathrm{~kg} / \mathrm{mm}^{2}$ is reached. It remains relatively unchanged for aging times up to $6000 \mathrm{~h}$. In the presence of large cyclic stresses, there is an additional increase in hardness and all specimens, with the exception of the $1500 \mathrm{~h}$ aged samples, show a final hardness in the range $140-190 \mathrm{~kg} / \mathrm{mm}^{2}$. The $1500 \mathrm{~h}$ aged specimens apparently do not have the ability to work harden to these values. This appears to be closely related to the metallurgical microstructure formed during the aging treatment which imparts a hardness only slightly higher than that for the as-heattreated condition (Figure 19). 


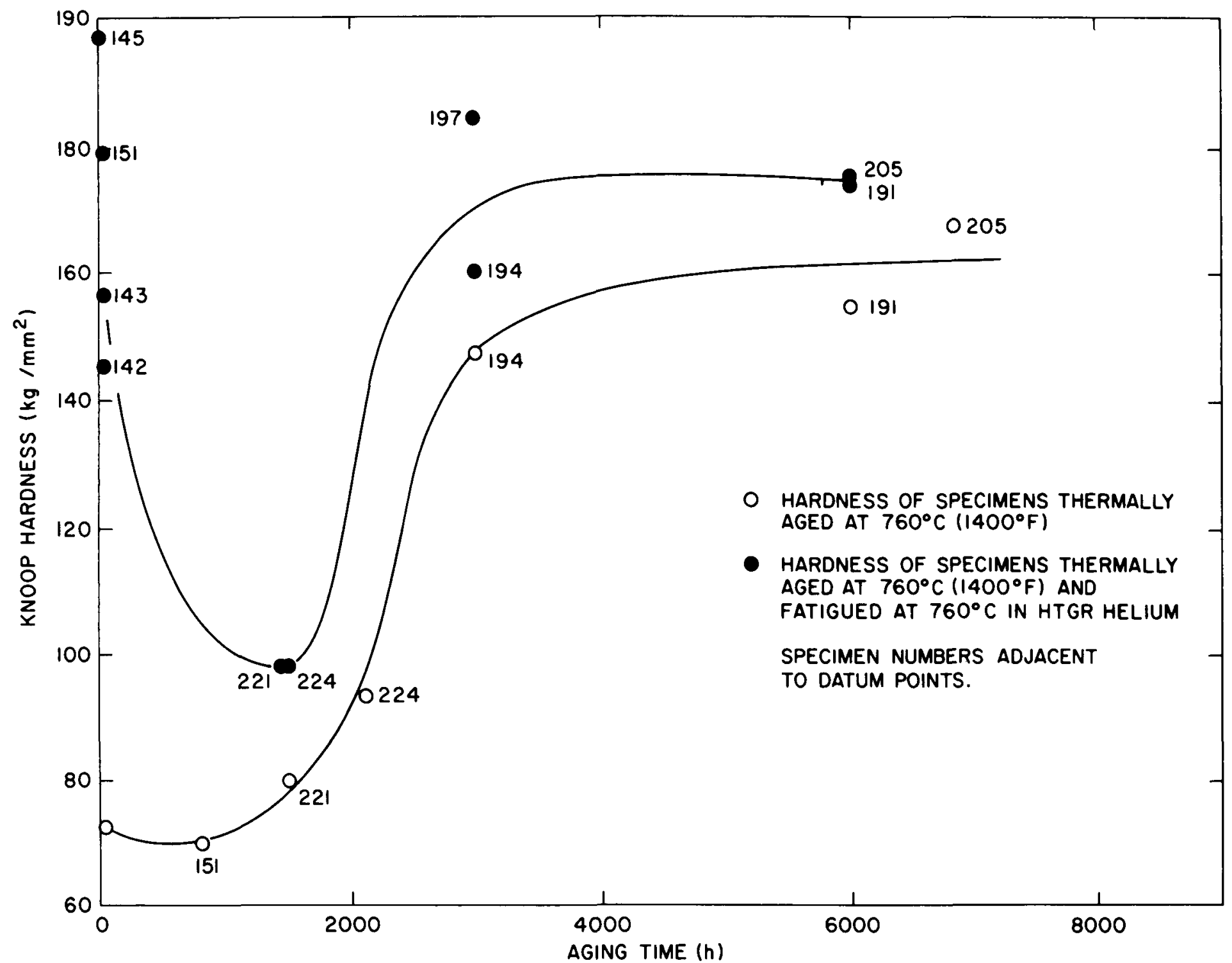

Figure 20. Effect of thermal aging and cyclic stressing on the microhardness of Incoloy $800 \mathrm{H}$. 


\subsection{Metallurgical Evaluations on Specimens Fractured at $649^{\circ} \mathrm{C}\left(1200^{\circ} \mathrm{F}\right)$}

From the fatigue curves shown in Figure 2 it can be seen that well defined fatigue limits exist for both test environments at $649^{\circ} \mathrm{C}\left(1200^{\circ} \mathrm{F}\right)$. Because of this it was difficult to obtain a range of stress levels for which fractographic analyses could be conducted. However, specimens MNF-163 (tested in air at $221 \mathrm{MPa}-32 \mathrm{ksi}, \mathrm{N}_{\mathrm{f}}=5.1 \times 10^{5}$ ) and MNF-184 (tested in helium at 241 $\mathrm{MPa}-35 \mathrm{ksi}, \mathrm{N}_{f}=6.0 \times 10^{6}$ ) may be compared to illustrate differences brought about by the test environments.

Figure 21 shows that in air tests the fracture surface is irregular in the regions close to the surface of the specimens. It appears that numerous small cracks have been initiated and they grow until incorporated into the main crack front. The principal crack initiation points are shown in Figure 22. As in the case for the $760^{\circ} \mathrm{C}\left(1400^{\circ} \mathrm{F}\right)$ results, initiation is associated with a well defined ridge lying approximately parallel to the crack propagation direction, which in Figure 22 is from the bottom to the top of the page. A comparison of the two surfaces shows that the air tested sample shows large smooth areas in which limited surface deformation is associated with the crack propagation process, i.e. the cracks propagate in a more brittle fashion in air when compared to the helium environment. The nature of the striations in Figure 23 is consistant with this pattern since the air test sample, although cycled at a significantly lower stress, has striations which were more sharply defined and more widely spaced.

Figure 24 shows the effect of environment on the fracture surface in an area adjacent to the edge of the samples. The cracks in this figure propagated from left to right. In the air test the surface is relatively flat, whereas in the case for the helium environment there is significant rumpling of the surface indicating that there is much deformation associated with the 

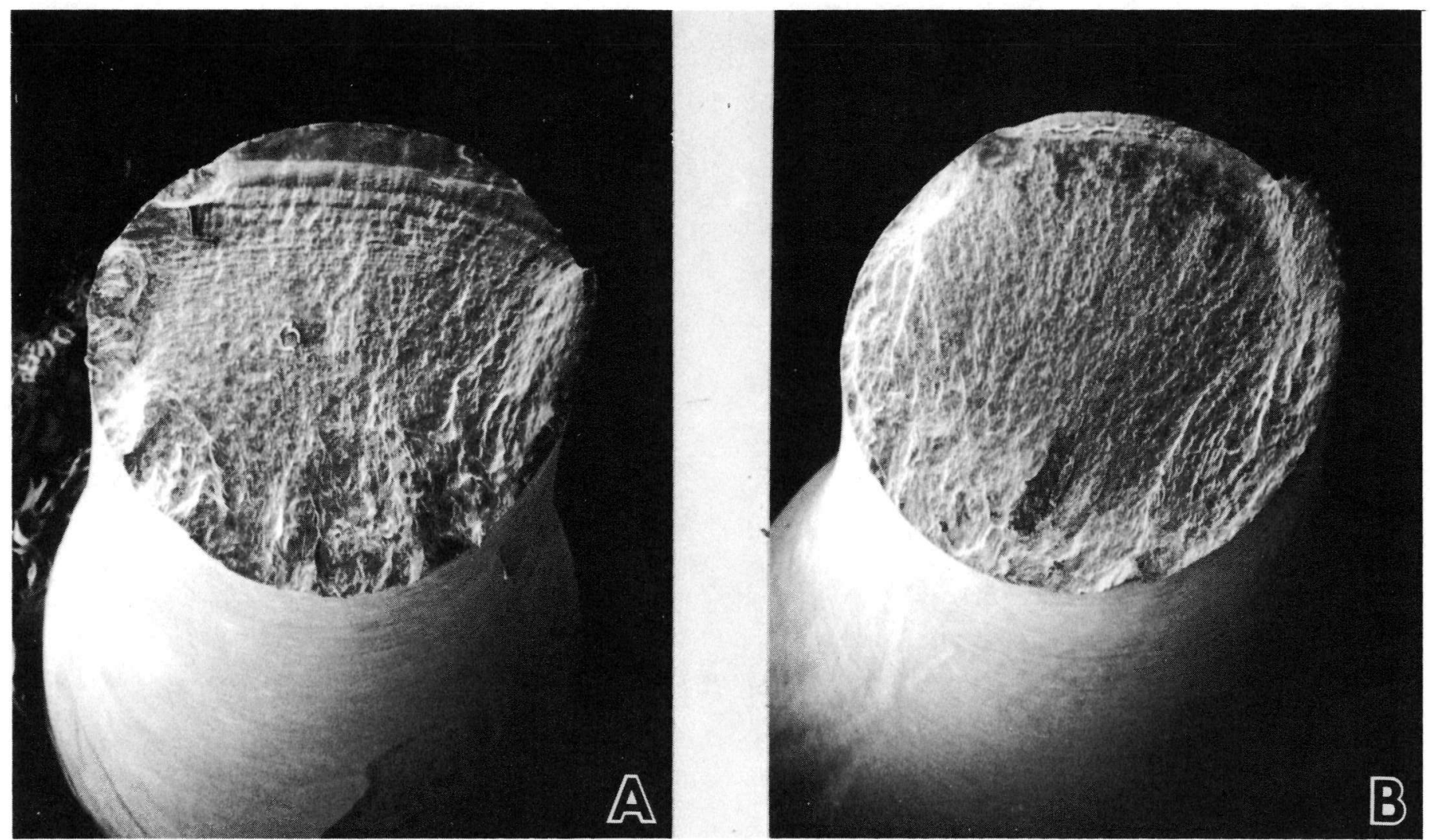

Figure 21. Effect of test environment on the fractography of Incoloy $800 \mathrm{H}$ high cycle fatigue specimens tested at $649^{\circ} \mathrm{C}\left(1200^{\circ} \mathrm{F}\right)$; (A) Specimen MNF-184 tested in air, (B) Specimen MNF-163 tested in HTGR helium. Magnifications $10 x$. 

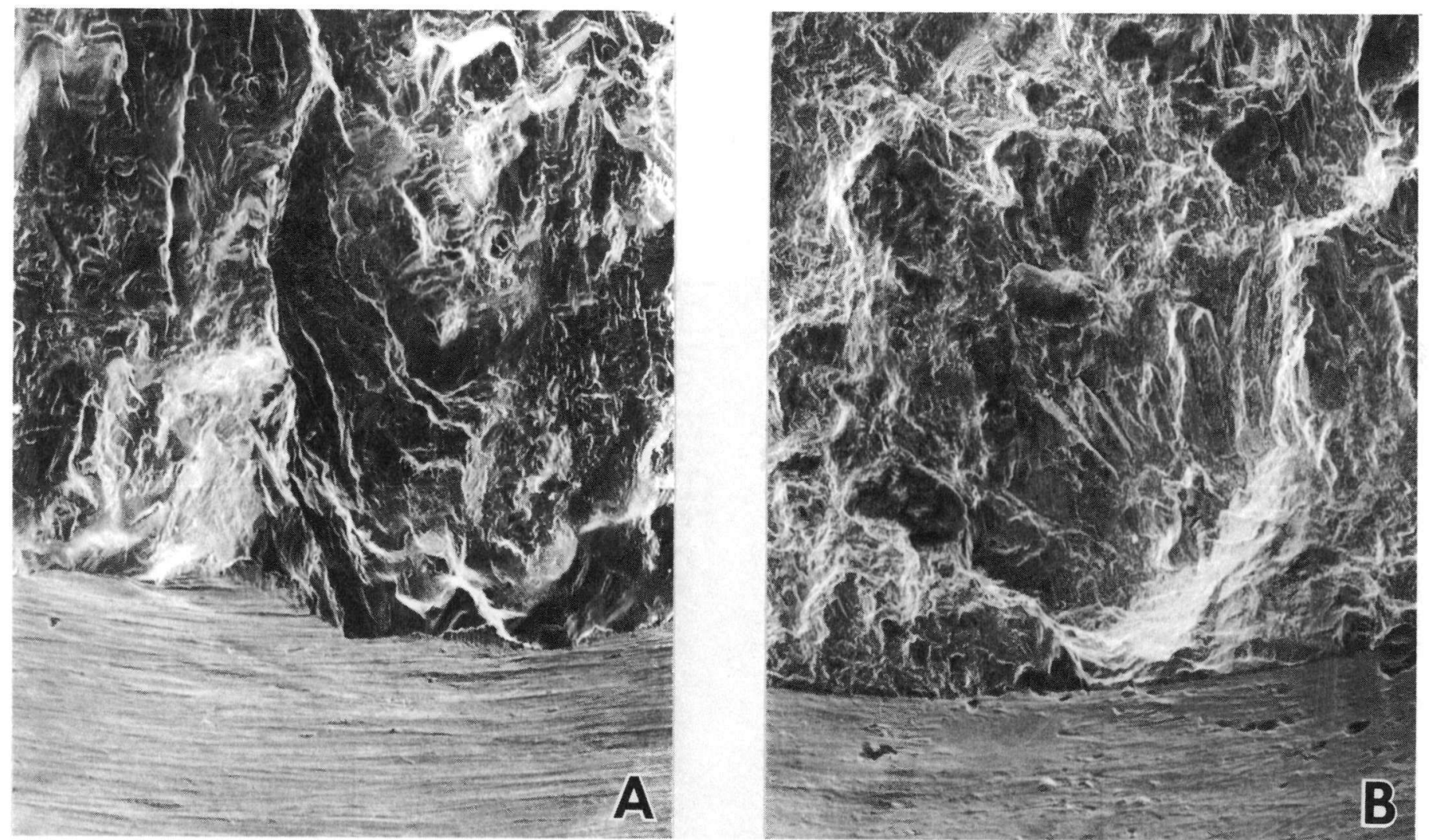

Figure 22. Effect of test environment on the crack initiation regions in Incoloy $800 \mathrm{H}$ high cycle fatigue specimens tested at $649^{\circ} \mathrm{C}\left(1200^{\circ} \mathrm{F}\right)$; (A) Specimen MNF-184 tested in air, (B) Specimen MNF-163 tested in HTGR helium. Magnifications $100 x$. 

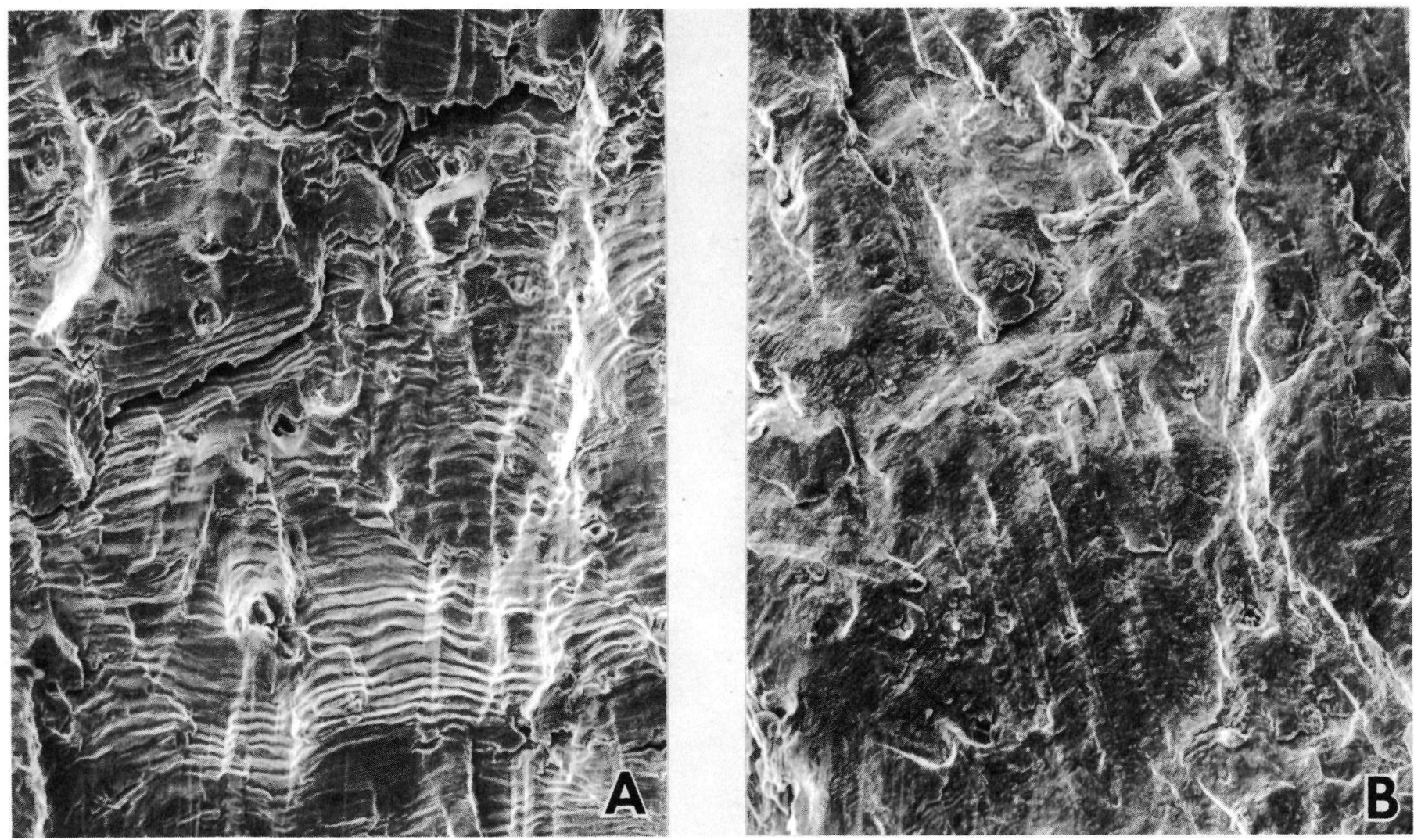

Figure 23. Effect of test environment on the nature of striations in Incoloy $800 \mathrm{H}$ high cycle fatigue specimens tested at $649^{\circ} \mathrm{C}\left(1200^{\circ} \mathrm{F}\right)$; (A) Specimen MNF-184 tested in air, (B) Specimen MNF-163 tested in HTGR helium. Magnifications $240 \mathrm{X}$. 

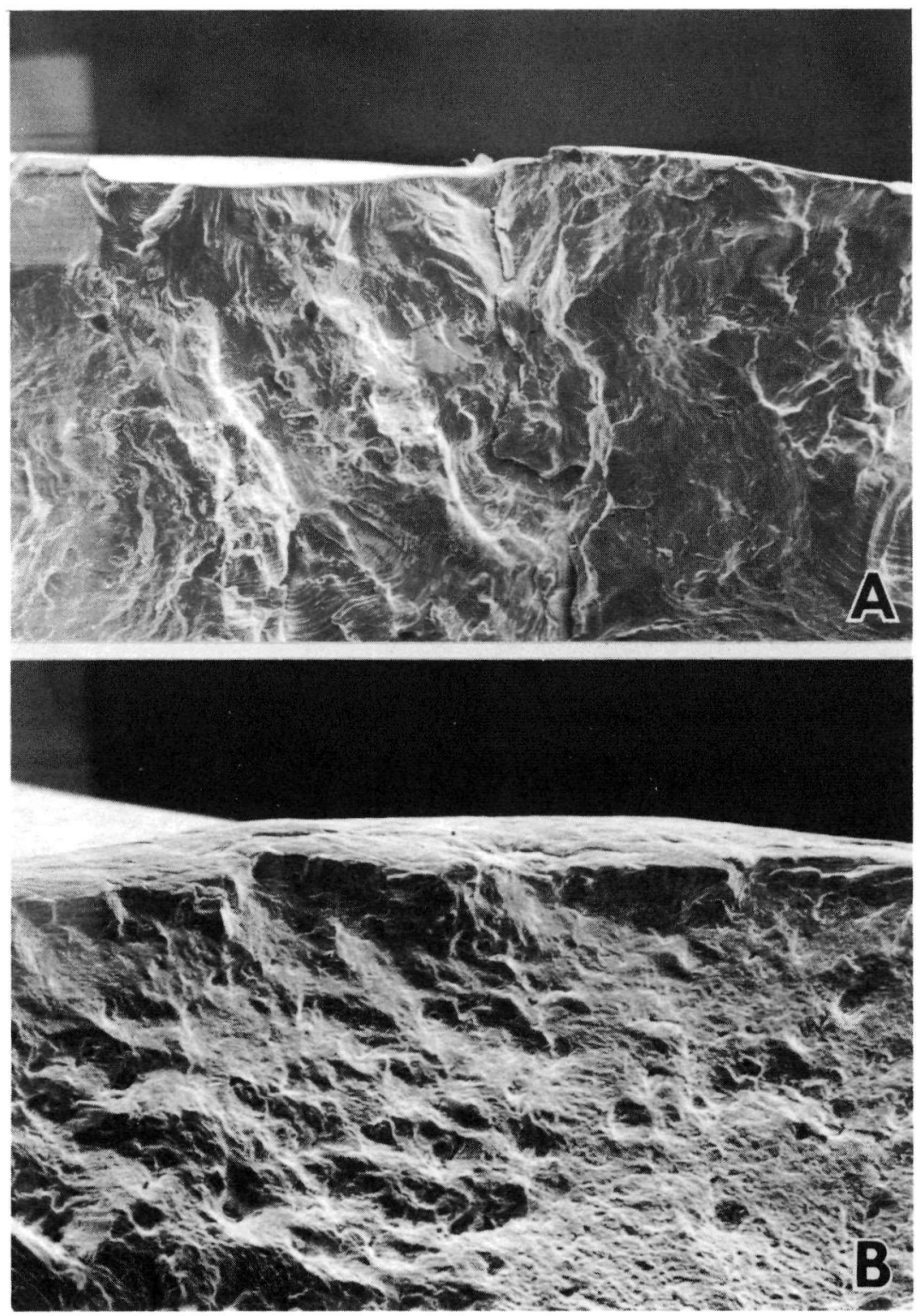

Figure 24. Appearances of edges of fracture surfaces in Incoloy $800 \mathrm{H}$ high cycle fatigue specimens tested at $649^{\circ} \mathrm{C}\left(1200^{\circ} \mathrm{F}\right) ;(\mathrm{A})$ Specimen MNF-184 tested in air, (B) Specimen MNF-163 tested in HTGR helium. Magnification $120 \mathrm{x}$. 
crack propagation process. This behavior is also observed during ductile dimple formation in areas close to the location where final specimen separation occurs (Figure 25). In the air test, few dimples are formed and the surface is relatively featureless. In the helium environment the number of dimples is far greater and there is more localized deformation on the fracture surface.

Figure 26 shows small oxidized particles in the fracture surface of a helium test specimen. It is significant that no such particles were observed in air tested samples

Generally, it seems that at $649^{\circ} \mathrm{C}\left(1200^{\circ} \mathrm{F}\right)$ air, when compared to helium, gives rise to a more embrittling type of fracture process with less plastic deformation associated with the crack propagation process. This is likely to be part of the reason that air gives a higher fatigue strength at this temperature.

\subsection{Metallurgical Evaluations on Specimens Fractured at $871^{\circ} \mathrm{C}\left(1600^{\circ} \mathrm{F}\right)$} The fractographs in Figure 27 show that at $871^{\circ} \mathrm{C}\left(1600^{\circ} \mathrm{F}\right)$ the crack propagation process in the air environment is dependent on the stress level. For a highly stressed (low $\mathrm{N}_{f}$ ) sample, two cracks were initiated and propagated towards each other. Since they were on widely separated planes the fractured surface contains a large step. At a lower stress level, fractures in air show a tendency to become intergranular. In the helium test environment the fractographs are basically similar to those for 649 and $760^{\circ} \mathrm{C}(1200$ and $\left.1400^{\circ} \mathrm{F}\right)$.

Crack initiation regions are shown in Figure 28. For specimen MNF-231 the surface displays relatively smooth regions indicative of a more brittle type of crack propagation, which is in contrast to the more deformed 

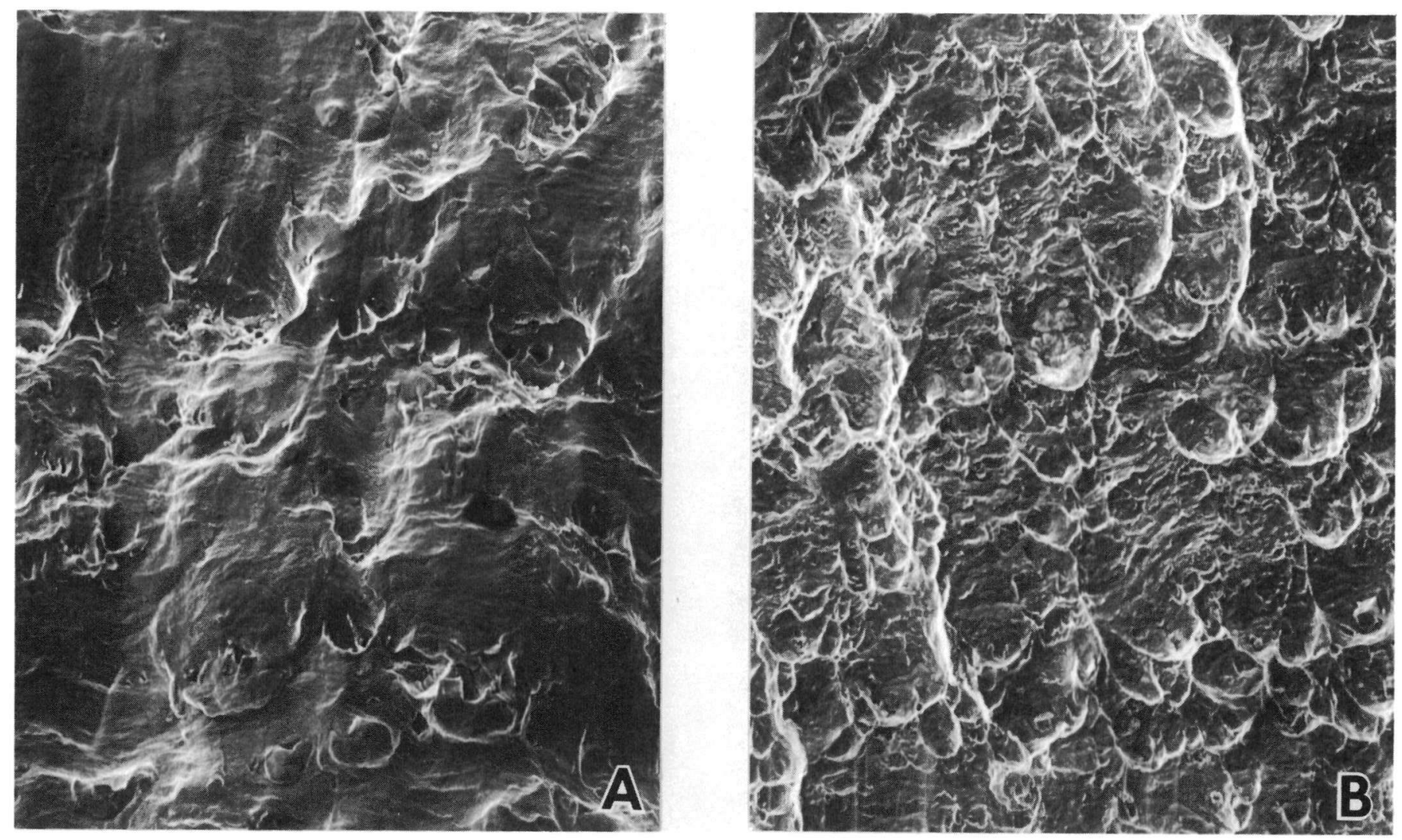

Figure 25. Stage III dimple formation in Incoloy $800 \mathrm{H}$ high cycle fatigue specimens tested in $649^{\circ} \mathrm{C}\left(1200^{\circ} \mathrm{F}\right)$; (A) Specimen MNF-184 tested in air, (B) Specimen MNF-163 tested in HTGR helium. Magnification 240X. 


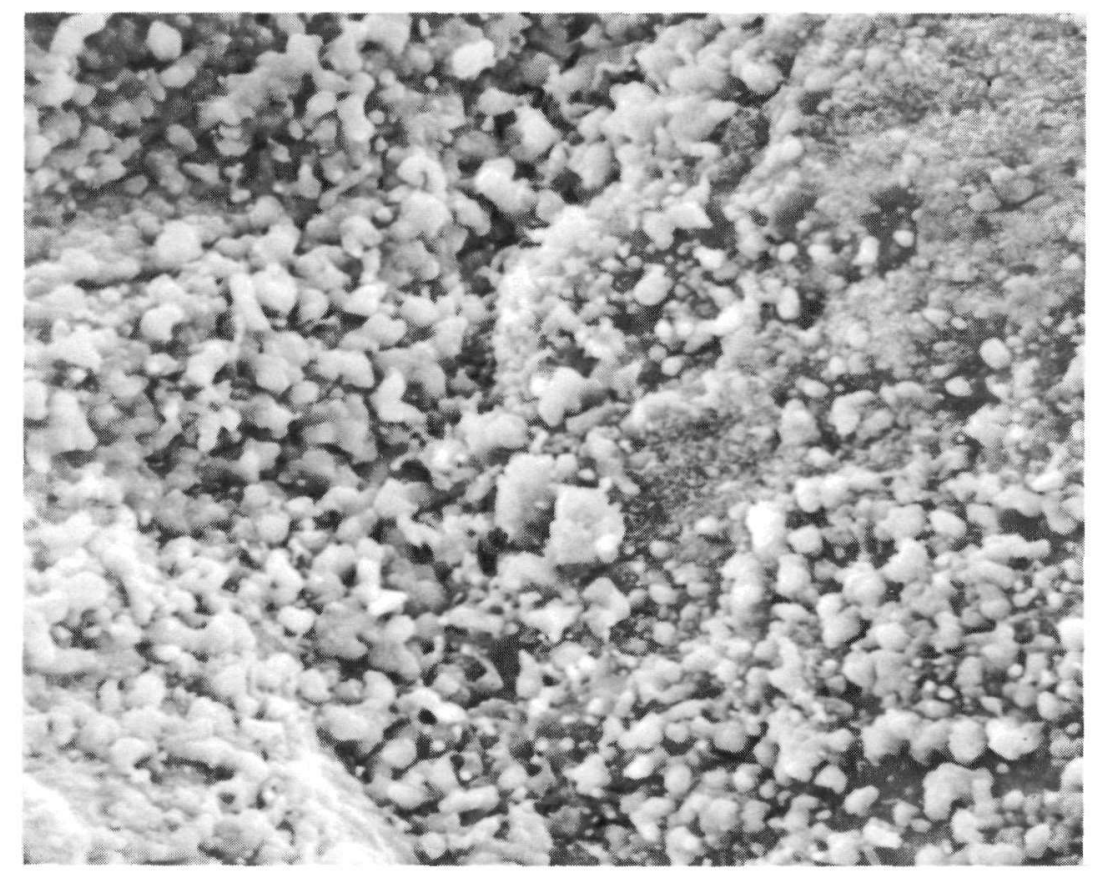

Figure 26. Oxidation products in the fracture surface of an Incoloy $800 \mathrm{H}$ high cycle fatigue specimen (MNF-163) tested in HTGR helium at $649^{\circ} \mathrm{C}\left(1200^{\circ} \mathrm{F}\right)$. Magnification $2400 x$.

surfaces observed in the helium tests. In common with the tests at $649^{\circ} \mathrm{C}$ $\left(1200^{\circ} \mathrm{F}\right)$, striations in the helium environment are very fine and irregular (Figure 29). In air they are much more pronounced, except in the case for low stress levels where intergranular fracture predominates.

Figure 30 again confirms that at $871^{\circ} \mathrm{C}\left(1600^{\circ} \mathrm{F}\right)$ air testing usually gives a more brittle type of crack propagation, with less plastic deformation present in the fracture surfaces.

The micrograph shown in Figure 31 shows that small oxidized particles are present in the fracture surfaces of specimens tested at $871^{\circ} \mathrm{C}\left(1600^{\circ} \mathrm{F}\right)$ in helium. These are very similar in appearance to those observed at other temperatures (Figures 13 and 26). An EDS X-ray scan shows the particles to be 

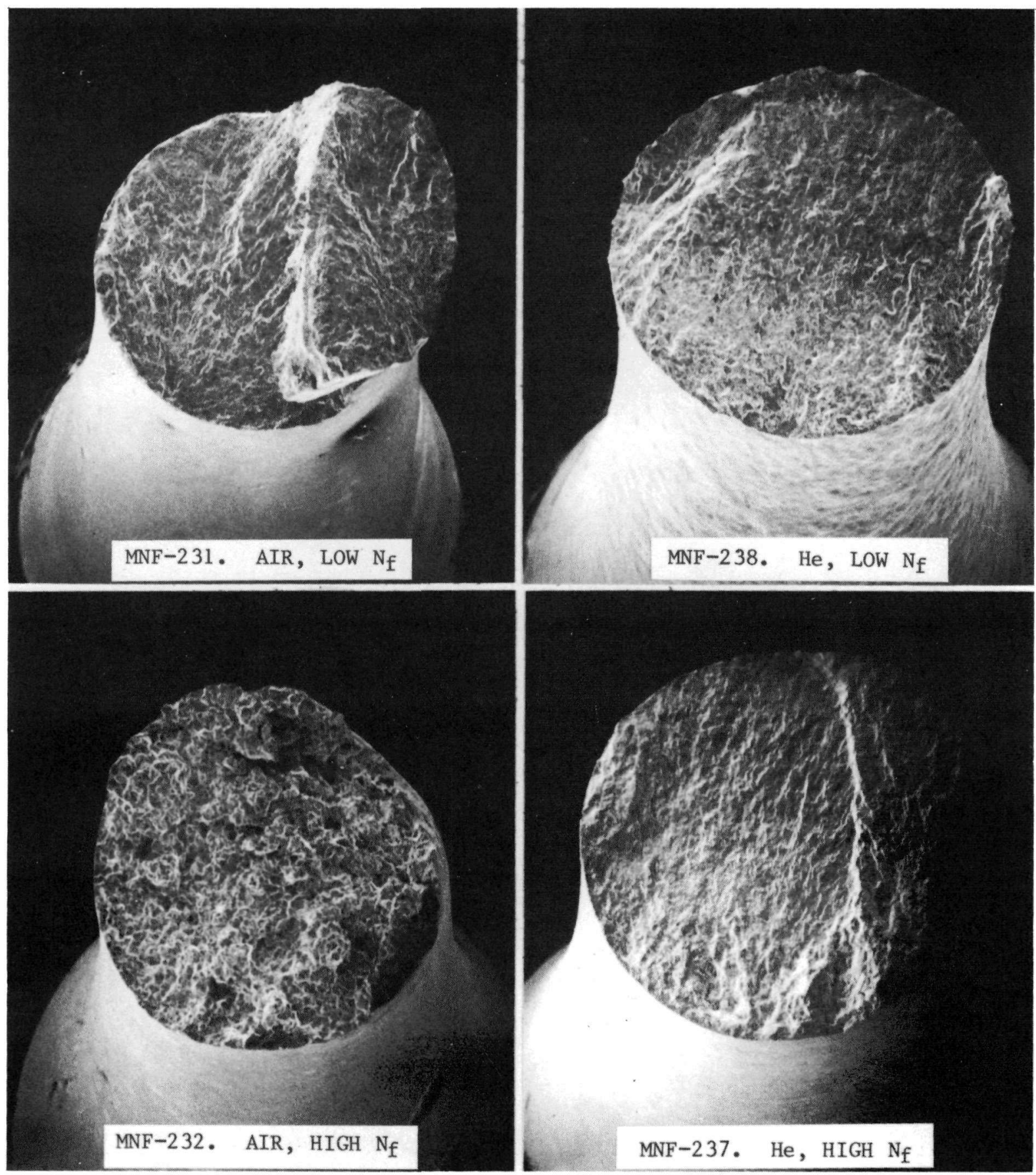

Figure 27. Fractographs of Incoloy $800 \mathrm{H}$. High cycle fatigue specimens tested at $871^{\circ} \mathrm{C}\left(1600^{\circ} \mathrm{F}\right)$ for various test environments and stress levels. Cracks propagated in upward direction. Magnifications approximately 10X. 

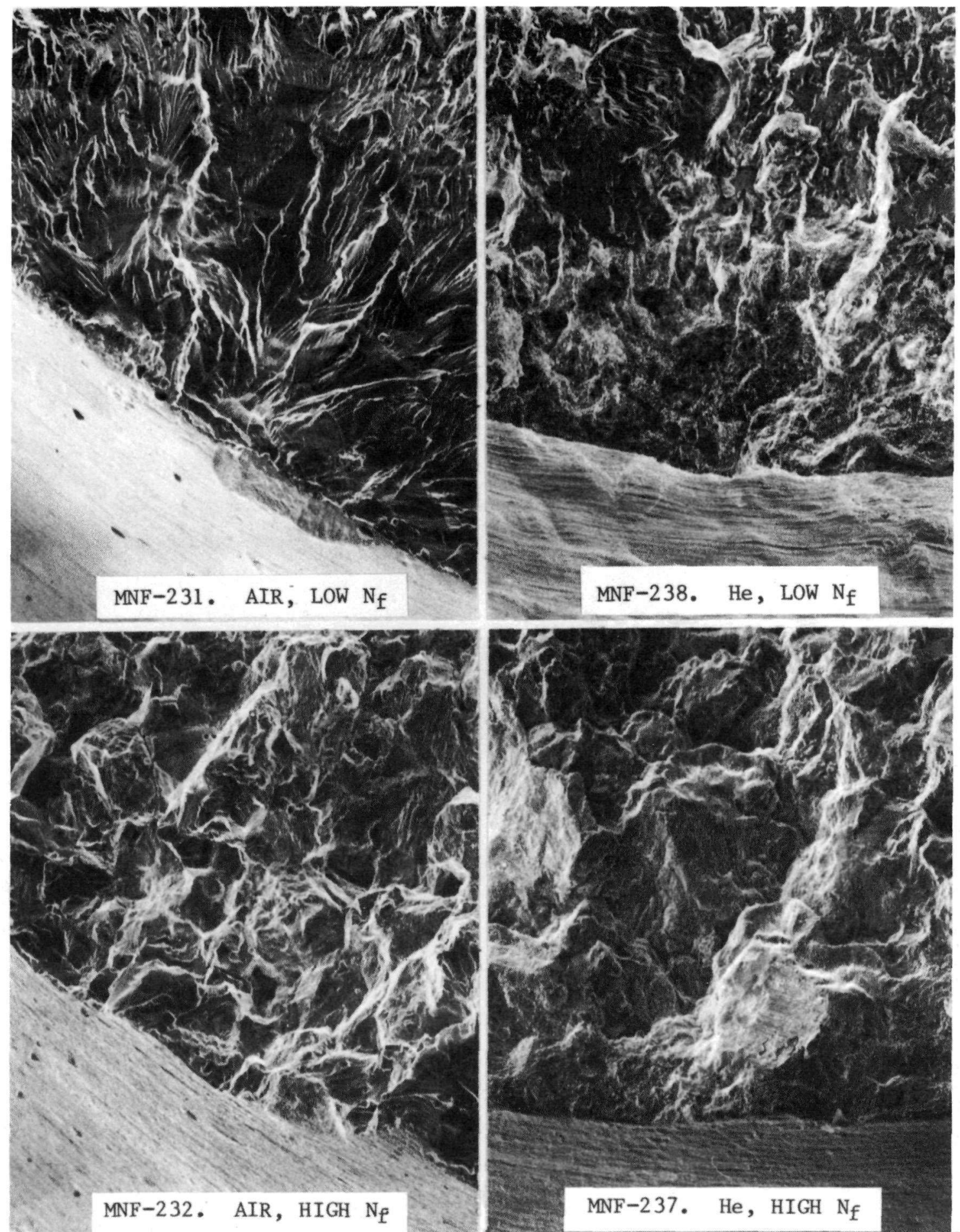

Figure 28. Crack initiation points in Incoloy $800 \mathrm{H}$ high cycle fatigue specimens tested at $871^{\circ} \mathrm{C}\left(1600^{\circ} \mathrm{F}\right)$ for various test environments and stress levels. Magnifications $100 x$. 

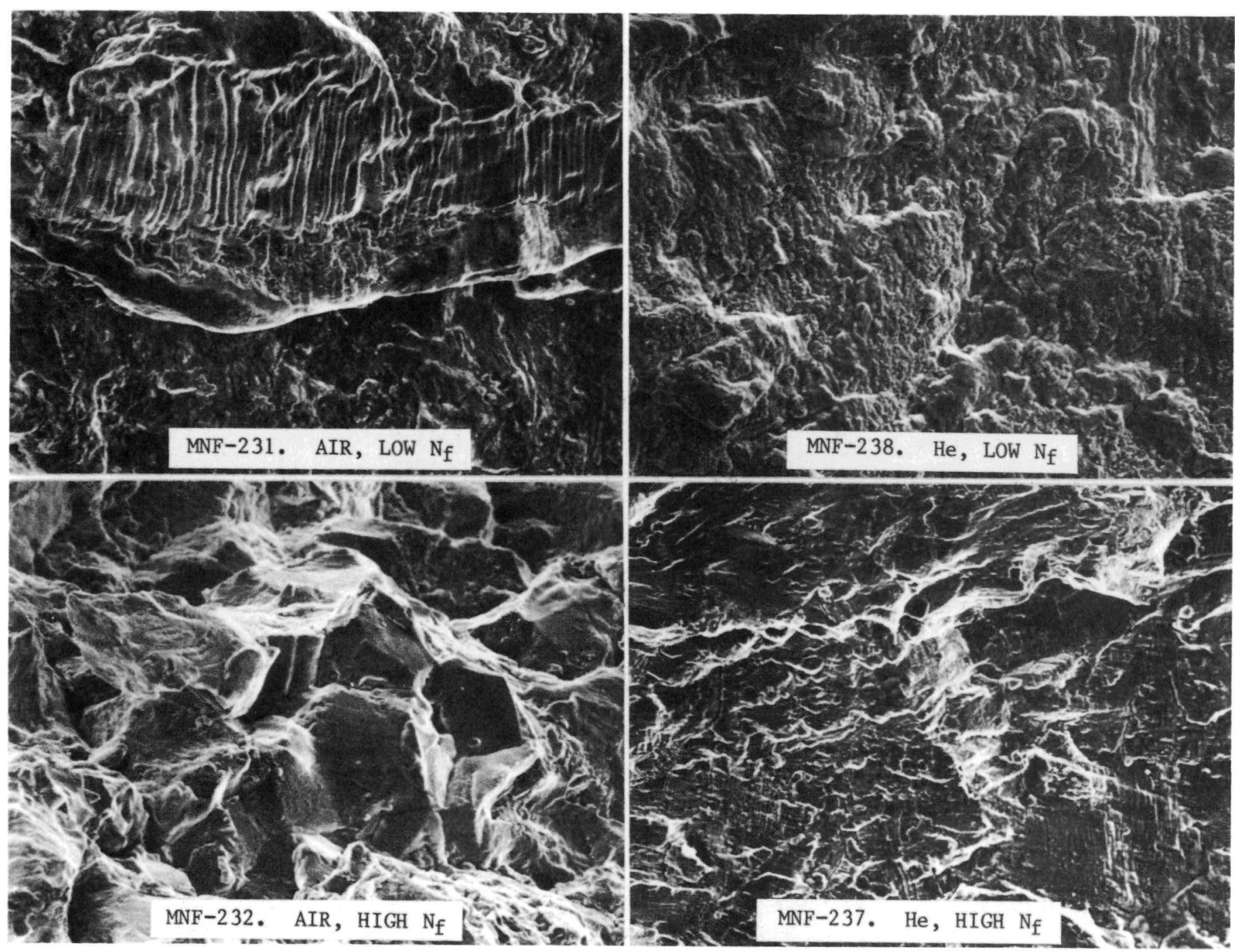

Figure 29. Crack propagation characteristics in Incoloy $800 \mathrm{H}$ high cycle fatigue specimens tested at $871^{\circ} \mathrm{C}\left(1600^{\circ} \mathrm{F}\right)$ for various test environments and stress levels. Cracks propagated from left to right. Magnifications 240X. 


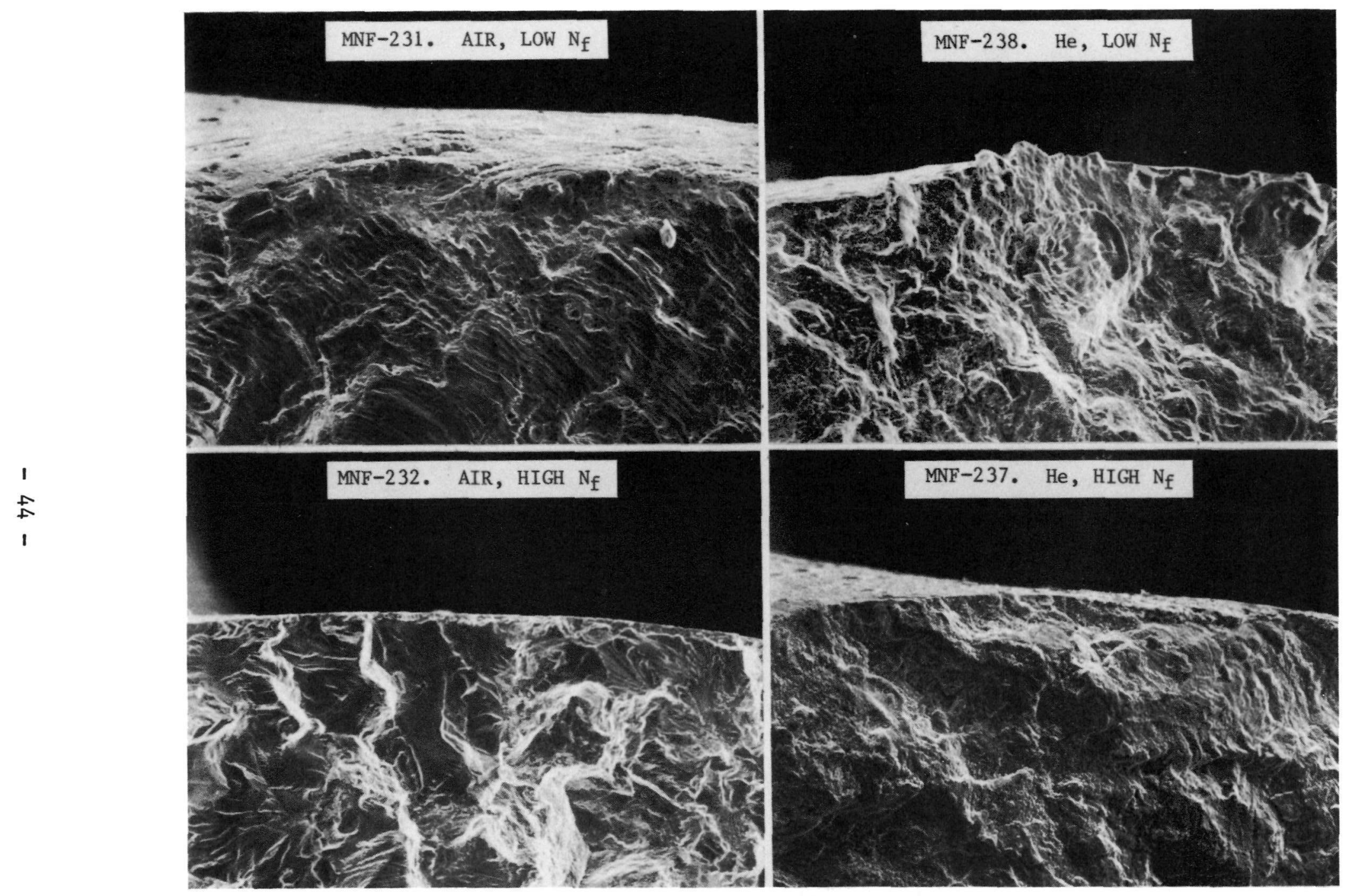

Figure 30. Appearance of edges of fracture surfaces in Incoloy $800 \mathrm{H}$ high cycle fatigue specimens tested at $871^{\circ} \mathrm{C}\left(1600^{\circ} \mathrm{F}\right)$ for various test environments and stress levels. Cracks propagated from left to right. Magnifications $120 x$. 

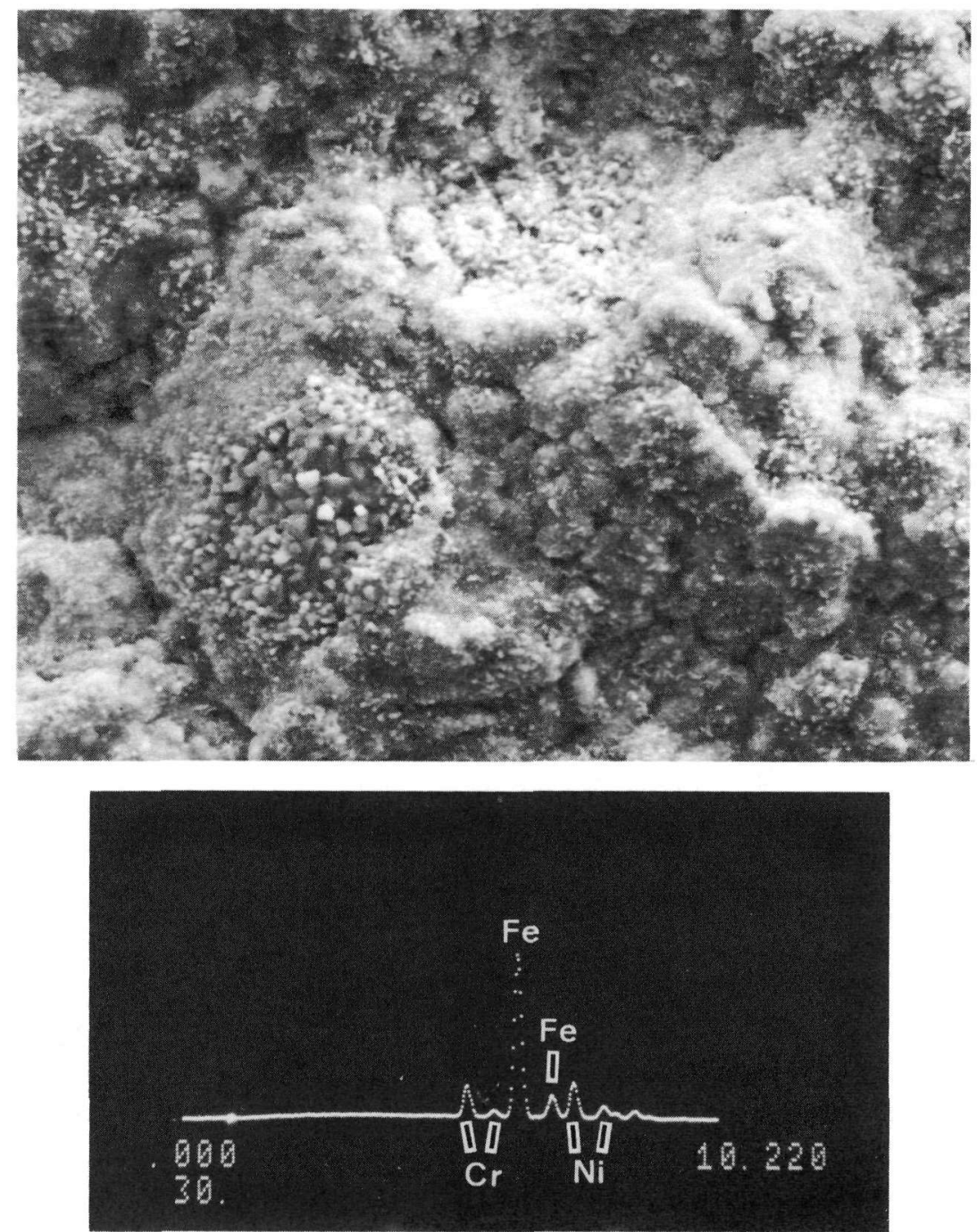

Figure 31. Scanning electron microscope/ microprobe EDS $X$-ray scan of oxidation products in the fracture surface of Incoloy $800 \mathrm{H}$ high cycle fatigue specimen (MNF-188 pre-aged in HTGR helium for $6000 \mathrm{~h} / 760^{\circ} \mathrm{C}\left(1400^{\circ} \mathrm{F}\right)$ and tested in the same environment at $760^{\circ} \mathrm{C}$. Magnification 1000X.

rich in iron with small amounts of chromium and nickel present. No comparable particles were observed in air tested specimens. 
Sectioned specimens are shown in Figures 32 and 33. The tendency for surface regions to recrystallize after long test times is illustrated. For fatigue crack propagation at low stress levels in air the tendency for intergranular failure is clearly observed.

\section{DISCUSSION}

This section will initially consider the effect of the test environment and test temperature on unaged Incoloy $800 \mathrm{H}$ and then the effects of pretest thermal aging will be discussed.

\subsection{Fatigue Strength of Unaged Incoloy $800 \mathrm{H}$}

In Figure 2 there are three obvious observations which must be addressed if a basic understanding of the fatigue processes is to be estab1ished:

- The observation that air is usually a more detrimental environment than HTGR helium with respect to fatigue strength. The exception occurs at a test temperature of $649^{\circ} \mathrm{C}\left(1200^{\circ} \mathrm{F}\right)$.

- At 538 and $649^{\circ} \mathrm{C}\left(1000\right.$ and $\left.1200^{\circ} \mathrm{F}\right)$ the effect of test environment is small at low $\mathrm{N}_{f}$ and large at high $\mathrm{N}_{f}$. At 760 and $871^{\circ} \mathrm{C}$ $\left(1400\right.$ and $\left.1600^{\circ} \mathrm{F}\right)$ the reverse behavior occurs and the environmental effect is large at low $\mathrm{N}_{f}$ and small at high $\mathrm{N}_{f}$.

- At the two lower test temperatures well defined fatigue limits are observed. Below these stress limits, fatigue failure is unlikely to occur even after indefinite cycling. At the two higher test temperatures the fatigue strengths decrease monotonically with increasing $\mathrm{N}_{\mathrm{f}}$. However, a pseudo fatigue limit does appear to be present at $871^{\circ} \mathrm{C}\left(1600^{\circ} \mathrm{F}\right)$ after about 108 cycles. 


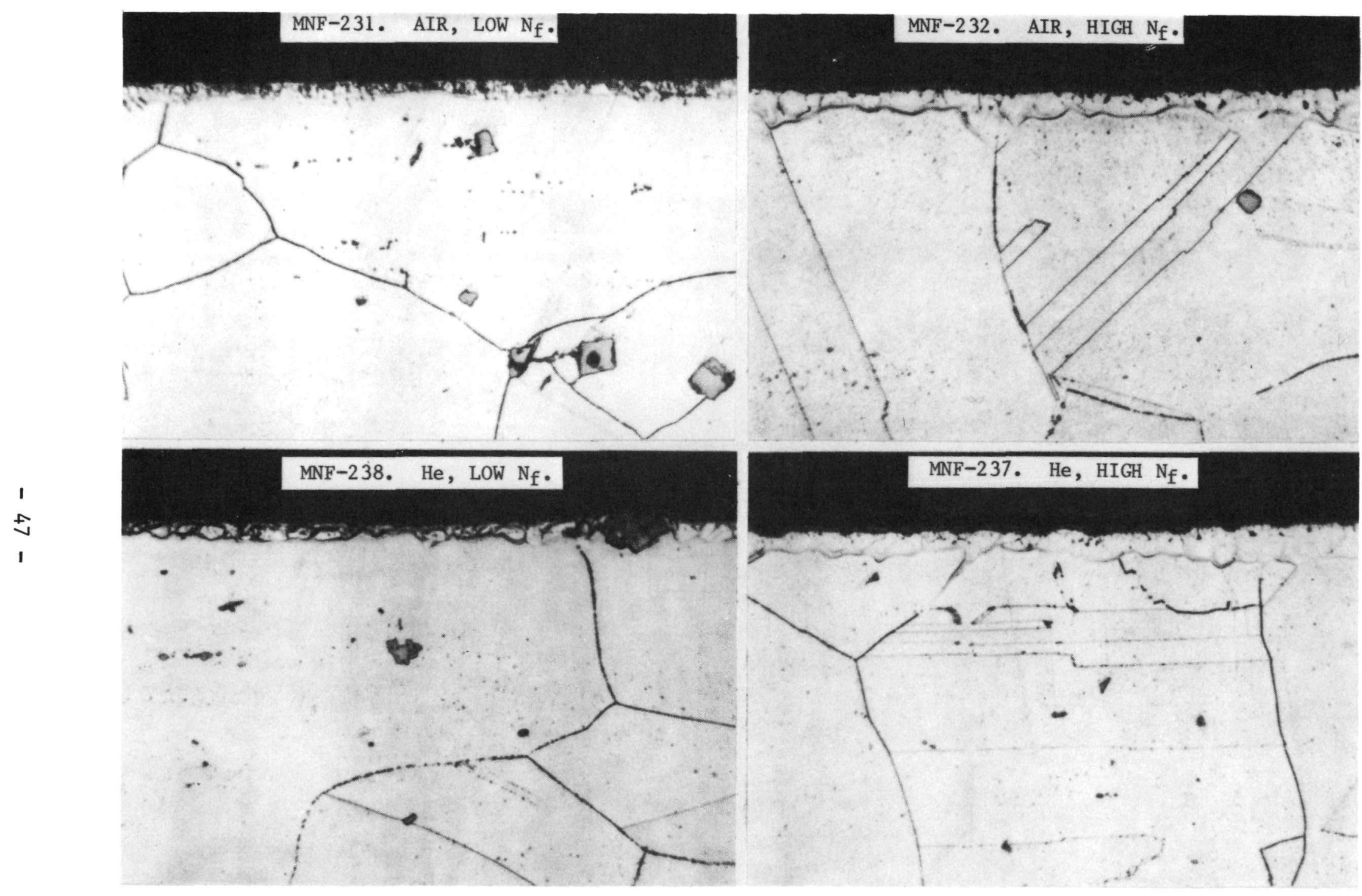

Figure 32. Surface recrystallization characteristics in Incoloy $800 \mathrm{H}$ high cycle fatigue specimens tested at $871^{\circ} \mathrm{C}\left(1600^{\circ} \mathrm{F}\right)$. Magnifications 500X. 


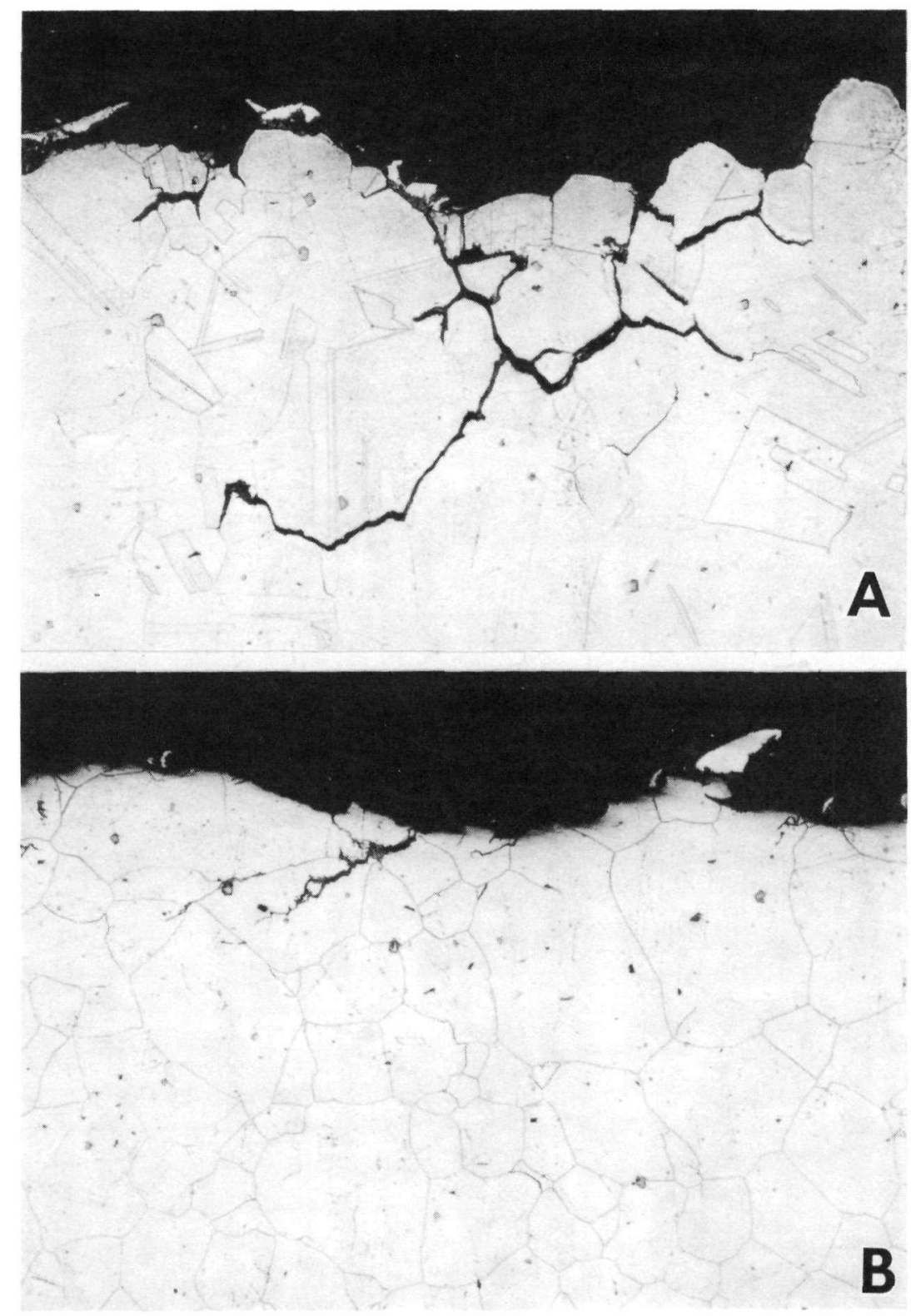

Figure 33. Sections through the fracture surfaces of Incoloy $800 \mathrm{H}$ high cycle fatigue specimens tested at $871^{\circ} \mathrm{C}$ $\left(1600^{\circ} \mathrm{F}\right) ;(\mathrm{A})$ Intergranular failure in specimen MNF-232 tested in air, (B) Transgranular failure in specimen MNF-237 tested in HTGR helium. Magnifications 100X. 


\subsubsection{Effect of Test Environment on Fatigue Strength}

The first factor, concerning mechanical strengths in different

environments, has been the source of numerous investigations. 3-5,7,9-11 Nearly all studies show that high temperature oxidation in air gives lower creep and fatigue strength when compared to gaseous envirorments which are either inert or contain only small quantities of air or moisture. Comprehensive reviews of such environmental effects have been jiven by Achter ${ }^{15}$ and Cook and Graham 7,10. From these studies, the more important factors which cause air to be the more detrimental environment were shown to be:

- Oxidation which can give large tensile stresses in the specimen surface.

- Intergranular oxidation of titanium and aluminum which prevents these elements from being available for gammaprime phase formation. This leads to a weakening of grain boundary areas.

- Oxidation at a crack tip which can accelerate crack propagation rates.

- Air oxidation which can lead to significant porosity beneath the oxide scale. The pores could act as crack nuclei i.

- Carburization in the helium test gas can lead to general strengthening and also decrease fatigue crack growth rates. There is ample evidence in the current work that air indeed does give a more detrimental effect on the fatigue strength when compared to the helium environment. One or more of the above models may be invoked to explain this effect. 
With regard to oxidation giving large tensile stress effects, it is possible that this could relieve some of the beneficial surface compressive stresses for the in-air tests. This would in turn result in air being a generally inferior environment with respect to fatigue strength, as observed. It is thought, however, that this mechanism is not appreciable in the current study since tests at $538^{\circ} \mathrm{C}\left(1000^{\circ} \mathrm{F}\right)$ show a strong environmental effect even though surface oxidation is minimal at the shorter test times.

Neither is the gamma-prime formation hypothesis likely to be appreciable here. This may be concluded from the observation that this phase forms only after about $1000 \mathrm{~h}$ at $600^{\circ} \mathrm{C}\left(1112^{\circ} \mathrm{F}\right)^{16}$. From the data in Figure 2 , strong environmental effects on the fatigue strength are observed for much shorter test times.

One of the more plausible explanations of the environmental effect centers on crack tip oxidation behavior. The fracture surfaces in $760^{\circ} \mathrm{C}\left(1400^{\circ} \mathrm{F}\right)$ tests (Figures 7 and 10$)$ show that the air test surfaces are less deformed than those for the helium studies. This indicates that the cracks propagate in a more brittle fashion in air and, most likely, at a faster rate. Similar results are observed for the $649^{\circ} \mathrm{C}\left(1200^{\circ} \mathrm{F}\right)$ tests (Figures 21 through 25$)$ and at $871^{\circ} \mathrm{C}\left(1600^{\circ} \mathrm{F}\right)$, see Figures 27 through 30 . It should be noted, however, that although cracks appear to propagate more rapidly in air at $649^{\circ} \mathrm{C}\left(1200^{\circ} \mathrm{F}\right)$ the fatigue strength in this environment is actually superior to that for helium. This will be discussed more fully below.

With respect to the lack of an environmental effect for low $\mathrm{N}$ tests at 538 and $649^{\circ} \mathrm{C}\left(1000\right.$ and $\left.1200^{\circ} \mathrm{F}\right)$ an explanation which may be proposed centers on the slower rates of oxidation at these temperatures. For short 
term tests of about $10^{4}$ cycles ( $\sim 4$ mins. duration) neither environment would be expected to give significant oxidation, hence, environmental effects would be sma11. For increasing test times the differences in the extent of oxidation in the two environments would become progressively greater and the fatigue strength curves for air and helium would diverge as seen in Figure 2. For testing at 760 and $871^{\circ} \mathrm{C}\left(1400\right.$ and $\left.1600^{\circ} \mathrm{F}\right)$ the oxidation rates would be much greater and differences in the fatigue strength for the air and helium environments would be significant even for short test times. For longer term tests the convergence of the air and helium test curves could be partly caused by the degree of oxidation in the helium gas approaching that for air. The basic assumption being that the two environments will eventually reach a comparable oxidation state but it takes a longer time to reach this for the helium environment. A more plausible explanation for the converging curves, however, is given in Section 4.1.3.

Porosity effects could also contribute to the detrimental effects of air on fatigue strength. Figure 15 shows that for unaged material the region below the scale in the air test contains significantly more cavities than for in-helium tests. An important additional feature to note in this respect is the different nature of the oxide scales which could influence the cavity formation process. The oxide formed in air is a $\mathrm{Cr} / \mathrm{Mn}$ oxide complex with the manganese layer being closer to the surface. In the case of the HTGR helium the oxidized layer contains significant amounts of iron, nickel, and titanium. Titanium is frequently seen in the scale of austenitic alloys oxidized in HTGR helium 6,12-14 but iron and nickel are not usually present. However, for certain oxide scales in pre-aged material, a similar effect is observed and this will be discussed in Section 4.2 below. 
Finally, carburization in the helium tests must also be considered. Cook has shown that in a test-gas very similar to the one used here (the main difference being that his environment was very dry) carburization is likely to occur at $800^{\circ} \mathrm{C}\left(1472^{\circ} \mathrm{F}\right)^{10}$. Although the carbon gradients in Figure 15 indicate that carburization in the specimens is minimal, it is still possible that the carbon detection limits in the scanning electron microscope/ microprobe are insufficiently sensitive to measure this element. Thus, at least some of the enhanced fatigue strength measured for the helium test environment may be attributable to carburization.

\subsubsection{Anomalous Environmental Effect at $649^{\circ} \mathrm{C}\left(1200^{\circ} \mathrm{F}\right)$}

The anomalous environment dependence of the Incoloy $800 \mathrm{H} \mathrm{fa-}$ tigue strength at $649^{\circ} \mathrm{C}\left(1200^{\circ} \mathrm{F}\right)$, shown in Figure 3 , is readily explainable. It is a real phenomenon since previous air-test work on a different heat of Incoloy $800 \mathrm{H}^{17}$ and on annealed Type 304 stainless steel ${ }^{18}$ confirms that the high cycle fatigue strength attains a peak value at elevated temperatures. On the other hand, the in-helium tests shown in Figure 3 give no indication of this behavior. Since the only difference between the two sets of tests is the test environment itself, then some surface effect must be responsible for the anomalous temperature dependence in air.

The observation in Figure 19 that recovery/recrystallization of the cold worked surface is very difficult in air, and quite likely in helium, provides some insight. At $649^{\circ} \mathrm{C}\left(1200^{\circ} \mathrm{F}\right)$ it is possible that oxygen or nitrogen from the air stabilizes the cold worked layer, thereby minimizing recovery/recrystallization. Specimen MNF-161 was tested for $2360 \mathrm{~h}$ without significant recrystallization occurring. The retention of the surface compressive stresses, therefore, enhances the fatigue strength. In addition, the 
presence of a dense array of dislocations in the surface region, which are strongly anchored by $\mathrm{M}_{23} \mathrm{C}_{6}$ particles, and which are known to precipitate more profusely at about $650^{\circ} \mathrm{C}\left(1200^{\circ} \mathrm{F}\right)^{19}$, will be a large added source of strengthening. No such strengthening is 1 ikely at $538^{\circ} \mathrm{C}\left(1000^{\circ} \mathrm{F}\right)$ since the kinetics of carbide precipitation are far slower ${ }^{19}$. Nor would it be present at $871^{\circ} \mathrm{C}$ $\left(1600^{\circ} \mathrm{F}\right)$ since $\mathrm{M}_{23{ }{ }_{6}}$ carbides go into solution at this temperature ${ }^{19}$.

In the helium test environment the cold worked layer is unstable and recovery/recrystallization occurs even for a short term test (Specimen MNF-162, Figure 19). Since the dislocation arrays formed by surface grinding are no longer able to serve as nucleation sites for $\mathrm{M}_{23} \mathrm{C}_{6}$ carbides, there is a very large loss in the surface strength. Hence, a peak fatigue strength at $650^{\circ} \mathrm{C}\left(1200^{\circ} \mathrm{F}\right)$ would not be expected, and this is confirmed by the data in Figure 3.

Another possible explanation of the peak strength effect at $649^{\circ} \mathrm{C}\left(1200^{\circ} \mathrm{F}\right)$ is dynamic strain aging. This has been observed by kaae in low cycle fatigue tests on Incoloy 800 at $538^{\circ} \mathrm{C}\left(1000^{\circ} \mathrm{F}\right)^{20}$. However, such a hypothesis is difficult to rationalize, since it is necessary to explain convincingly why a peak strength effect does not occur for the helium test gas.

\subsubsection{Fatigue Limit Effects}

The presence of a well defined fatigue limit at the two lower test temperatures indicates that there is an overall tendency for the metal to maintain its hardness for long times. If there is significant softening, from cyclic stressing and/or stress relief from processes such as recovery or recrystallization, then a continuous decrease in fatigue strength would be likely. Figure 34 shows stress relief data for various cold worked austenitic stainless steels which were held at different temperatures for varying lengths 


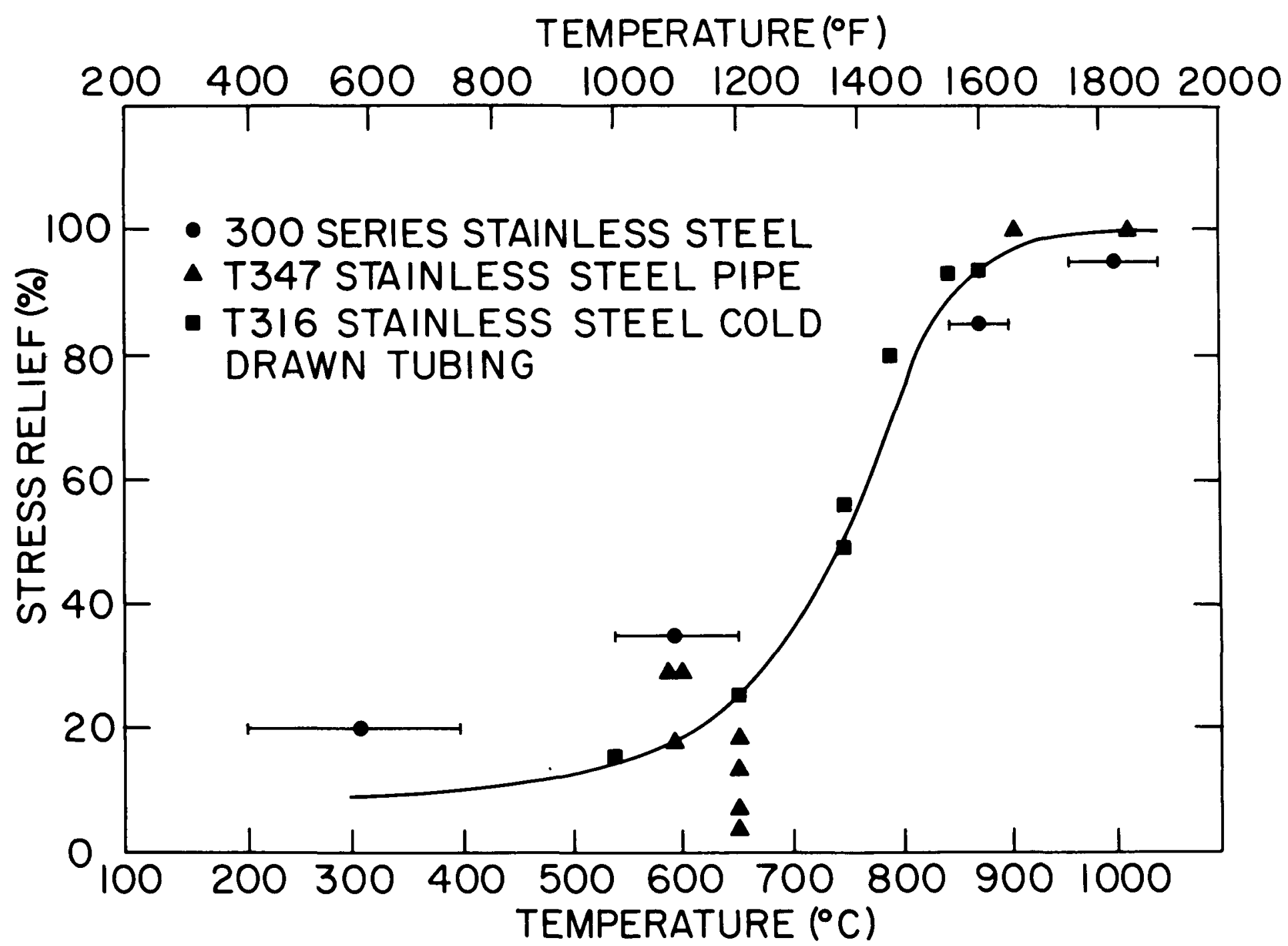

Figure 34. Effect of annealing temperature on the amount of stress relief in cold worked austenitic stainless steels. 
of time. Although the amounts of cold work and hold times varied, it is clear that significant stress relief only begins at temperatures in excess of approximately $650^{\circ} \mathrm{C}\left(1200^{\circ} \mathrm{F}\right)$. Complete stress relief (recrystallization) is achieved at $871^{\circ} \mathrm{C}\left(1600^{\circ} \mathrm{F}\right)$ and higher. If these data are a reasonable indication of the behavior of Incoloy $800 \mathrm{H}$, then the well defined fatigue limits at 538 and $649^{\circ} \mathrm{C}\left(1000\right.$ and $\left.1200^{\circ} \mathrm{F}\right)$ may be explained on the basis that at these two test temperatures, surface grinding stresses induced during specimen fabrication are not significantly changed by in-test recovery or recrystallization. Since these stresses are known to be compressive in nature, and beneficial to fatigue resistance 21 , no reduction in fatigue strength is likely during test. Similarly, cyclic hardening processes during the fatigue process are also not likely to undergo recovery during test.

For 760 and $871^{\circ} \mathrm{C}\left(1400\right.$ and $\left.1600^{\circ} \mathrm{F}\right)$, however, the results in Figure 34 show that recovery/recrystallization phenomenon are highly probable. The data in Figures 14 and 19, taken from tests conducted on unaged samples at $760^{\circ} \mathrm{C}$ (MNF-151 and MNF-152), clearly show that recrystallization of the surface layer has occurred after about $10^{7}$ cycles, which is precisely the time at which the in-helium test curve in Figure 2 begins to show an accelerated strength loss trend. Although no microhardness data are available for $871^{\circ} \mathrm{C}$ $\left(1600^{\circ} \mathrm{F}\right)$ tests, the micrographs in Figure 32 also show that recrystallization is present. An enlarged view of the micrographs for the unaged material in Figure 14 is given in Figure 35. For the long term tests it is seen that in areas adjacent to the surface, the grain boundaries are denuded of chromium carbides. This indicates that the chromium rich oxide scale formed during test, has created a sub-scale region depleted of chromium. Apparently, this region of reduced corrosion resistance is the direct cause of the observed large numbers of corrosion cracks or pits which are, in turn, likely to be 

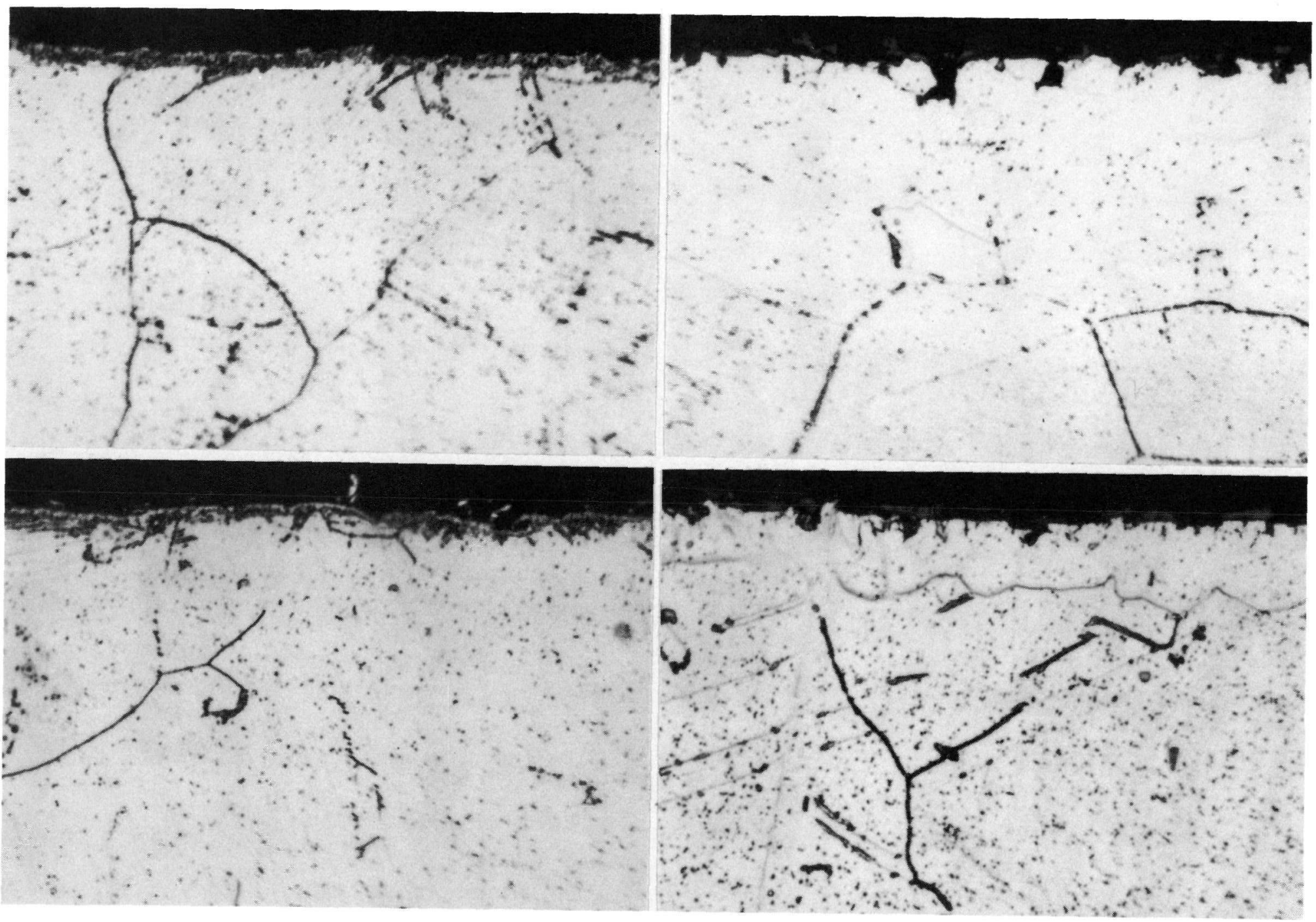

Figure 35. Recrystallization and cracking in Incoloy $800 \mathrm{H}$ high cycle fatigue specimens tested at $760^{\circ} \mathrm{C}\left(1400^{\circ} \mathrm{F}\right)$ for various test environments and stress levels. Magnifications $1000 \mathrm{X}$. 
fatigue crack nucleii. Figure 36 shows a fatigue crack in a helium test carried out at $871^{\circ} \mathrm{C}\left(1600^{\circ} \mathrm{F}\right)$. Note the large amount of corrosion associated with the surfaces of the crack. A crack formed in air at $760^{\circ} \mathrm{C}\left(1400^{\circ} \mathrm{F}\right)$ during a very short term test shows no evidence of this type of corrosion. It may, therefore, be postulated that the large decreases observed in the fatigue strength for material tested in HTGR helium at 760 and $871^{\circ} \mathrm{C}\left(1400\right.$ and $1600^{\circ} \mathrm{F}$ ) after long term cycling is a corrosion-fatigue process which is intimately connected with recrystallization in the chromium depleted surface regions. Specimens tested in air may also be susceptible to this type of corrosionfatigue but little convincing evidence has so far been gathered.

Figure 2 shows that pre-aged materials also show an identical tendency to display a rapid decrease in fatigue strength as $N_{f}$ increases. This suggests that corrosion-fatigue processes also play a role in aged microstructures. A full discussion of this is given in the following section.

\subsection{Fatigue Strength of Pre-aged Incoloy $800 \mathrm{H}$}

The work on pre-aged samples was initiated to determine how long term corrosion could influence fatigue strength in HTGR environments. The two most important observations which need to be discussed are:

- The large loss in fatigue strength in material which has been pre-aged for $1500 \mathrm{~h}$ at $760^{\circ} \mathrm{C}\left(1400^{\circ} \mathrm{F}\right)$ in the test helium prior to fatiguing. This effect is closely connected with scale exfoliation during test, surface recrystallization, bulk hardness, cyclic work hardening behavior, and deep intergranular attack.

- The tendency for all aged materials to show an accelerated strength loss trend after about $10^{7}$ accumulated cycles. Unaged materials tested in helium also show this effect. 

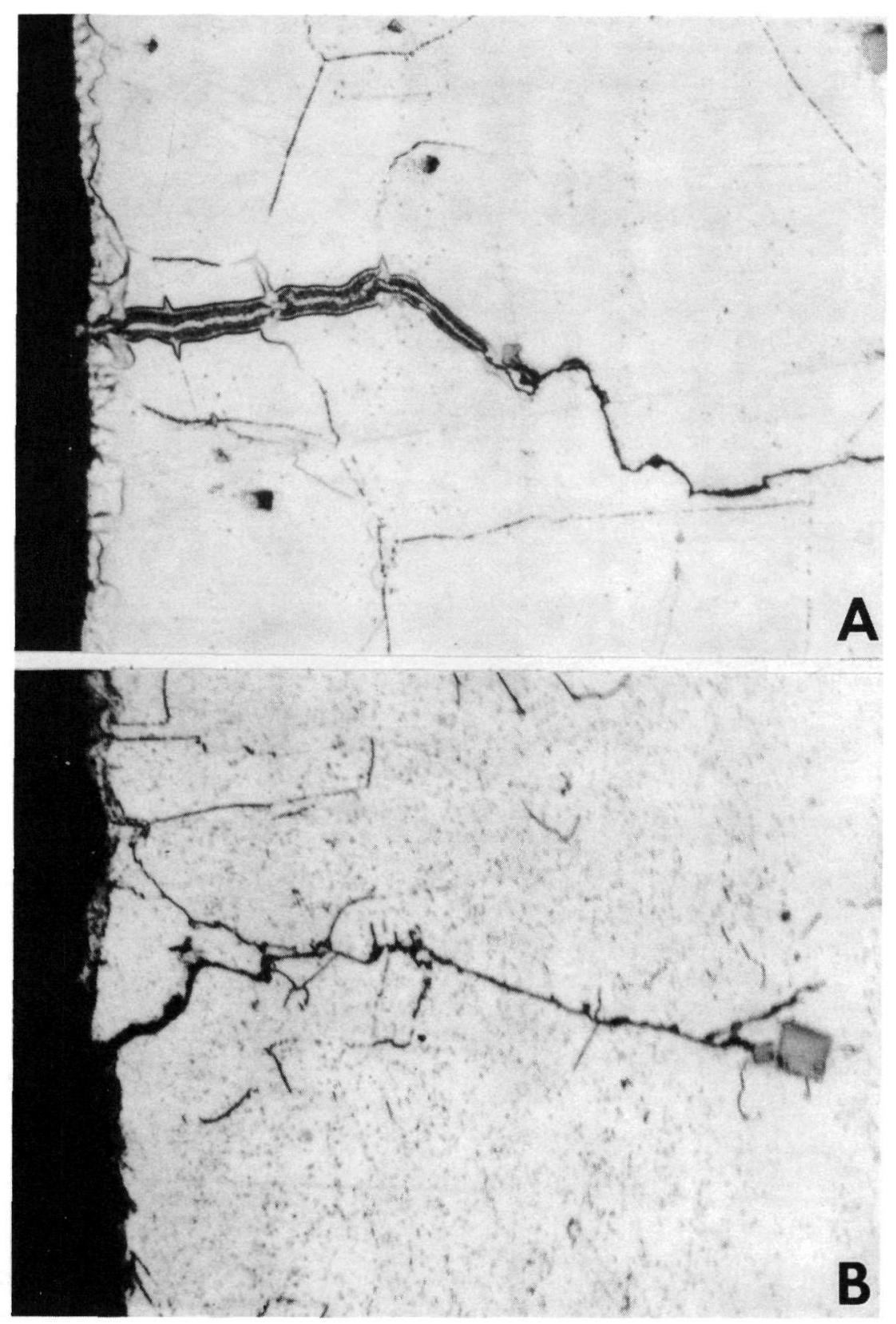

Figure 36. Nature of fatigue cracks in Incoloy $800 \mathrm{H}$ high cycle fatigue specimens; (A) Corrosion-fatigue crack in specimen MNF-238 tested at $871^{\circ} \mathrm{C}\left(1600^{\circ} \mathrm{F}\right)$ in HTGR helium, (B) Regular fatigue crack in specimen MNF-138 tested at $760 \mathrm{C}(1400 \mathrm{~F})$ in air. Magnifications $500 x$. 


\subsubsection{Effects of Aging on Fatigue Strength at $760^{\circ} \mathrm{C}\left(1400^{\circ} \mathrm{F}\right)$ \\ The $10^{8}$ cycle fatigue strength at $760^{\circ} \mathrm{C}\left(1400^{\circ} \mathrm{F}\right)$ as a function}

of pretest thermal aging time is shown in Figure 5 . After $1500 \mathrm{~h}$ the fatigue strength has decreased by approximately 15 percent compared to unaged material. The strength loss is recovered after $6000 \mathrm{~h}$ of aging but there is again a small strength loss after $10,500 \mathrm{~h}$. The large amount of scale exfoliation (Figure 9), together with the abnormal surface oxidation characteristics (Figures 14 and 15), suggest that a connection exists between the two phenomena. As discussed in Section 3.1.3, the oxidation rate is stress dependent. Most likely, the stress dependent scale exfoliation process is enhanced by the fact that recrystallization, and attendant grain boundary migration and grain nucleation and growth, would probably lead to decohesion between the oxide scale and subscale region. Another contributing factor to scale exfoliation concerns the low bulk hardness of the $1500 \mathrm{~h}$ aged material (approximately 100 $\mathrm{kg} / \mathrm{mm}^{2}$, Figure 19). Under a given cyclic stress level, this material would show a larger strain than material with a higher bulk hardness. Note also that the low hardness of these samples gives a low cyclic work hardening rate (Figure 20).

Scale exfoliation alone would be unlikely to cause the large strength loss observed in $1500 \mathrm{~h}$ aged specimens. From Figures 14 and 15, it may be seen that in regions which have lost the original $\mathrm{Cr} / \mathrm{Mn}$ oxide scale, the chromium depleted region becomes susceptible to oxidation. From data on the free energies of formation of various metal oxides 6 , iron forms a more stable oxide than nickel. This is in agreement with current results which show that an iron oxide is formed on the newly exposed surface. The moisture in the helium environment is able to penetrate the nickel rich area below the 
iron oxide, along cracks such as those shown in Specimen MNF-221 (Figures 11 and 13), until it traverses the chromium depleted region and forms a fresh layer of chromium oxide. The nickel in the zone between the surface iron oxide layer and the subsurface chromium oxide region remains in the metallic state since any nickel oxide would be unstable and easily reduced in the presence of excess chromium and iron. Specimen MNF-151 (Figure 15), which was exposed to helium during a test lasting about $700 \mathrm{~h}$, also shows evidence of iron and nickel concentrations overlaying a $\mathrm{Cr} / \mathrm{Mn}$ oxide. This may be taken as being an early stage of scale rupture which permits iron oxide formation in regions where chromium has been depleted.

In the case of the 3000 and $6000 \mathrm{~h}$ pre-aged specimens (Figures 14 and 15$)$, the $\mathrm{Cr} / \mathrm{Mn}$ oxide scale is more intact than that at $1500 \mathrm{~h}$. Although recrystallization, which commences after about $100 \mathrm{~h}$ at $760^{\circ} \mathrm{C}\left(1400^{\circ} \mathrm{F}\right)$, may initially disrupt the integrity of the oxide scale, it does not exfoliate in the absence of a cyclic stress. Continual aging reconsolidates the oxide layer and titanium oxide also forms readily at these longer times. In addition, many of the small recrystallized grain boundaries, which permit rapid moisture penetration in the $1500 \mathrm{~h}$ aged specimens, have apparently been removed by long term aging.

The very deep intergranular cracks observed in the $1500 \mathrm{~h}$ aged specimens (Figure 14) are not related to the fine cracks observed in the small recrystallized surface grains. The latter are probably a result of their being located in a chromium depleted zone. The major grain boundaries, however, are not formed from recrystallized material, so that any changes in grain boundary characteristics must result from the $1500 \mathrm{~h}$ aging treatment. As mentioned previously in Section 3.1 .3 sensitization occurs, caused by 
chromium carbide precipitation at the grain boundaries. 19 This is demonstrated very vividly by the heavy etching of the boundaries in the $1500 \mathrm{~h}$ specimens (Figure 14). Shorter and longer aging times show far less sensitization. In the $1500 \mathrm{~h}$ specimens, a combination of scale exfoliation and sensitized grain boundaries permits rapid moisture penetration and cracking down the boundaries. Although the cracks are initially intergranular, they may eventually become transgranular as shown in Specimen MNF-221 (Figure 14). This type of cracking is thus a special form of corrosion-fatigue.

\subsubsection{Corrosion-Fatigue Effects for Long Term Tests}

The tendency for the 760 and $871^{\circ} \mathrm{C}\left(1400\right.$ and $\left.1600^{\circ} \mathrm{F}\right)$ fatigue curves to show a monotonic decrease with increasing $N_{f}$ and especially the accelerated rate of strength loss for cycles in excess of $10^{7}$ is indicative of structural instability during testing. It may be related to cyclic softening, thermally induced effects such as recovery and recrystallization, corrosion, or a combination of all three. Figures 36 and 37 show fatigue cracks observed in various test specimens. Although every test sample was not examined metallographically it seems that the corrosion associated with the cracks is only observed in specimens tested in the helium environment. Fracture surface studies (Figures 13, 26 and 31 ) show that oxidation products in the form of small particles are present in the helium tested samples. They do not cover the entire surface but are locallized to a large area near the crack initiation points. For air testing, well defined particles are not observed (Figure 13).

An EDS X-ray analysis of the particles in Figure 31 shows them to be rich in iron with smaller quantities of chromium and nickel. A similar result was obtained for Specimen MNF-224, which was aged for $1500 \mathrm{~h}$ at $760^{\circ} \mathrm{C}$ 

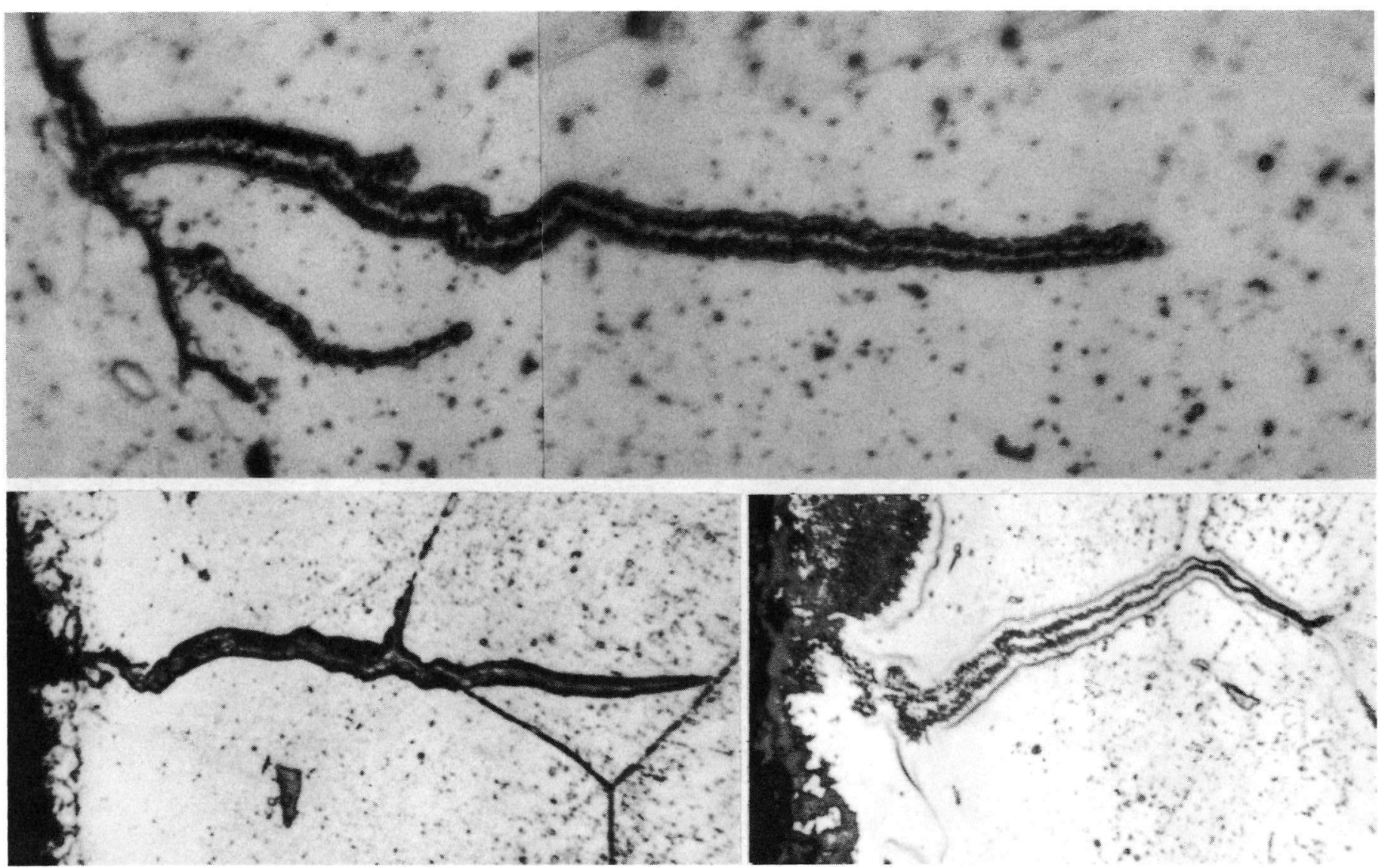

Figure 37. Corrosion-fatigue cracks in Incoloy $800 \mathrm{H}$ high cycle fatigue specimens tested in HTGR helium; (A) Specimen MNF-221 pre-aged in HTGR helium for $3000 \mathrm{~h} / 760^{\circ} \mathrm{C}\left(1400^{\circ} \mathrm{F}\right)$, Magnification $1000 \mathrm{X}$, (B) Specimen MNF-221 preaged in HTGR helium for $1500 \mathrm{~h} / 760^{\circ} \mathrm{C}\left(1400^{\circ} \mathrm{F}\right)$, Magnification $1000 \mathrm{X}$, (C) Specimen MNF-224 pre-aged in HTGR helium for $1500 \mathrm{~h} / 760^{\circ} \mathrm{C}\left(1400^{\circ} \mathrm{F}\right)$, Magnification 1000X. 
$\left(1400^{\circ} \mathrm{F}\right)$. At first sight it seems unusual that iron oxide, rather than chromium oxide, should form. However, the fracture surface is only exposed to the helium environment for a very short time before the specimen is cooled and removed from the test capsule. Since the alloy contains about 42 percent iron it is obvious that some iron oxide will form. For extended exposures, proportionately more chromium oxide will be present.

The oxide particle sizes in Figure 13 clearly show that for long term tests there is a larger amount of oxidation associated with the crack propagation process. This is consistent with a corrosion-fatigue process becoming increasingly important with high endurance tests. The increased strength loss tendency for cyclic lives in excess of $10^{7}$ may, therefore, be explained in this manner. However, the precise reason for the increased corrosion rates at propagating crack tips for the lower stress levels is not fully understood at this time. It could possibly be due to a combination of deformation at the crack tip and the microstructure developed during cycling. Whatever the reason, it is probable that the accelerated strength loss for long term testing is a result of a more aggressive corrosion-fatigue process.

\section{CONCLUSIONS}

The current study is an attempt to evaluate the high cycle fatigue strength of Incoloy $800 \mathrm{H}$ in an HTGR helium environment which simulates a hypothetical accident scenario in which a water/steam leak into the primary system occurs. The various parameters which determine the fatigue life are manifold, and complex synergistic interactions are sometimes observed. Tests were carried out on as-machined specimens as well as on specimens which had first been pre-aged in the test helium in order to quantify the effects of long term 
corrosion on the fatigue strength. Some of the more important findings for unaged material are as follows:

- At 538,760 and $871^{\circ} \mathrm{C}\left(1000,1400\right.$ and $\left.1600^{\circ} \mathrm{F}\right)$ air testing gives a lower fatigue strength when compared to the wet helium environment. This is due to the more brittle nature of the crack propagation process in air. At $649^{\circ} \mathrm{C}\left(1200^{\circ} \mathrm{F}\right)$ air gives a higher strength owing to the presence of surface compressive stresses in the cold worked surface layers together with profuse carbide precipitation in this region.

- Carburization reactions in the helium test gas may be present and contribute to the generally higher strength in this environment. However, based on metallographic observations this effect is thought to be quite small, if indeed it is present.

- There is an accelerated loss in fatigue strength once the number of accumulated fatigue cycles exceeds about $10^{7}$. This is likely to be associated with enhanced crack-tip corrosion, i.e. a type of corrosion-fatigue process is likely. At the higher test temperatures surface recrystallization may also be a contributing factor to the strength loss.

- At 538 and $649^{\circ} \mathrm{C}\left(1000\right.$ and $\left.1200^{\circ} \mathrm{F}\right)$ a well defined fatigue limit exists. This is most probably associated with the stability of the cold work surface layer in the specimens, together with an internal work hardened substructure which is itself resistant to recovery processes.

For pre-aged material the following additional conclusions may be drawn: 
- No pre-aging treatment gives a fatigue strength which is inferior to that in air. The use of air test data in the analysis of watercontaining helium environments similar to that used in this study is, therefore, likely to be conservative.

- A pre-aging treatment of $1500 \mathrm{~h}$ at $760^{\circ} \mathrm{C}\left(1400^{\circ} \mathrm{F}\right)$ in the test helium gives the largest decrease in fatigue strength which becomes comparable to that for air. The decrease is a direct result of a corrosionfatigue process brought about by several synergistic effects which include surface recrystallization, rapid general oxidation in a chromium depleted zone caused by stress induced scale exfoliation, and deep intergranular attack caused by sensitization.

- For longer aging times of 3000 and $6000 \mathrm{~h}$ the extended aging reconsolidates the scale and exfoliation during test is less likely. Corrosion-fatigue, although still present, is less serious than that for the $1500 \mathrm{~h}$ aging treatment.

- As with unaged material there is an accelerated decrease in the fatigue strength for all pre-aged conditions once $10^{7}$ cycles have been accumulated. This is caused by the same corrosion-fatigue process in which crack-tip oxidation is more severe at the extended test times.

With the exception of the $649^{\circ} \mathrm{C}\left(1200^{\circ} \mathrm{F}\right)$ tests on unaged material, none of the data obtained show definitively that the in-helium tests give a fatigue strength that is inferior to that in air. Hence, for the wet helium environment studied no significant adverse effect of the simulated HTGR gas has been identified at this time. 


\section{ACKNOWLEDGEMENTS}

The authors gratefully appreciate the assistance of $\mathrm{C}$. H. Brewster who operated the Materials Test Loop, C. J. Schnepf who performed the optical metallography, M. A. McGrath who typed the manuscript. We are also grateful for stimulating discussions and encouragement received from J. G. Y. Chow, C. Sastre and D. G. Schweitzer. 


\section{Table 1}

Chemical Composition of Incoloy $800 \mathrm{H}$

Test Material (Heat HH7427A)

\section{Element}

$\mathrm{Cr}$

$\mathrm{Ni}$

$\mathrm{Ti}$

AT

$\mathrm{Cu}$

$\mathrm{Mn}$

Si

S

C

$\mathrm{Fe}$
Concentration (wt. percent)

19.83

32.17

0.43

0.39

0.65

0.67

0.46

0.003

0.05

Balance 
Table 2

High Cycle Fatigue Data for Incoloy $800 \mathrm{H}$ as a

Function of Test Environment and Temperature

\begin{tabular}{|c|c|c|c|c|c|c|c|}
\hline $\begin{array}{c}\text { Spec. } \\
\text { No. } \\
\end{array}$ & $\begin{array}{l}\text { Test } \\
\left({ }^{\circ} \mathrm{C}\right)\end{array}$ & $\begin{array}{l}\text { Temp } \\
\left({ }^{\circ} \mathrm{F}\right) \\
\end{array}$ & $\begin{array}{c}\text { Test } \\
\text { Environment } \\
\end{array}$ & $\begin{array}{l}\text { Cyclic } \\
(\mathrm{MPa})\end{array}$ & $\begin{array}{r}\text { Stress } \\
(\mathrm{ksi})\end{array}$ & $\begin{array}{l}\text { Cycles to } \\
\text { Failure (Nf) }\end{array}$ & Notes \\
\hline $\begin{array}{l}\text { MNF }-246 \\
\text { MNF-247 } \\
\text { MNF-248 } \\
\text { MNF-249 } \\
\text { MNF }-250 \\
\text { MNF }-252 \\
\text { MNF-257 }\end{array}$ & $\begin{array}{l}538 \\
538 \\
538 \\
538 \\
538 \\
538 \\
538\end{array}$ & $\begin{array}{l}1000 \\
1000 \\
1000 \\
1000 \\
1000 \\
1000 \\
1000\end{array}$ & $\begin{array}{l}\text { Air } \\
\text { Air } \\
\text { Air } \\
\text { Air } \\
\text { Air } \\
\text { Air } \\
\text { Air }\end{array}$ & $\begin{array}{l}276.0 \\
255.0 \\
241.0 \\
228.0 \\
207.0 \\
172.0 \\
159.0\end{array}$ & $\begin{array}{l}40.0 \\
37.0 \\
35.0 \\
33.0 \\
30.0 \\
25.0 \\
23.0\end{array}$ & $\begin{array}{r}7.5 \times 10^{3} \\
3.8 \times 10^{4} \\
3.3 \times 10^{4} \\
1.5 \times 10^{5} \\
3.0 \times 10^{5} \\
9.0 \times 10^{6} \\
>1.6 \times 10^{8}\end{array}$ & \\
\hline $\begin{array}{l}M N F-254 \\
M N F-261 \\
M N F-258 \\
M N F-262 \\
M N F-253 \\
M N F-263\end{array}$ & $\begin{array}{l}538 \\
538 \\
538 \\
538 \\
538 \\
538\end{array}$ & $\begin{array}{l}1000 \\
1000 \\
1000 \\
1000 \\
1000 \\
1000\end{array}$ & $\begin{array}{l}\text { Helium } \\
\text { Helium } \\
\text { Helium } \\
\text { Helium } \\
\text { Helium } \\
\text { Helium }\end{array}$ & $\begin{array}{l}276.0 \\
262.0 \\
241.0 \\
234.0 \\
228.0 \\
228.0\end{array}$ & $\begin{array}{l}40.0 \\
38.0 \\
35.0 \\
34.0 \\
33.0 \\
33.0\end{array}$ & $\begin{array}{r}6.7 \times 10^{4} \\
2.0 \times 10^{4} \\
1.2 \times 10^{6} \\
1.1 \times 10^{5} \\
>1.1 \times 10^{8} \\
>4.4 \times 10^{6}\end{array}$ & (1) \\
\hline $\begin{array}{l}\text { MNF-164 } \\
\text { MNF-169 } \\
\text { MNF-229 } \\
\text { MNF-184 } \\
\text { MNF-156 } \\
\text { MNF-171 } \\
\text { MNF-161 } \\
\text { MNF-165 } \\
\text { MNF-157 } \\
\text { MNF-154 }\end{array}$ & $\begin{array}{l}649 \\
649 \\
649 \\
649 \\
649 \\
649 \\
649 \\
649 \\
649 \\
649\end{array}$ & $\begin{array}{l}1200 \\
1200 \\
1200 \\
1200 \\
1200 \\
1200 \\
1200 \\
1200 \\
1200 \\
1200\end{array}$ & $\begin{array}{l}\text { Air } \\
\text { Air } \\
\text { Air } \\
\text { Air } \\
\text { Air } \\
\text { Air } \\
\text { Air } \\
\text { Air } \\
\text { Air } \\
\text { Air }\end{array}$ & $\begin{array}{l}262.0 \\
248.0 \\
241.0 \\
241.0 \\
241.0 \\
239.0 \\
234.0 \\
228.0 \\
221.0 \\
207.0\end{array}$ & $\begin{array}{l}38.0 \\
36.0 \\
35.0 \\
35.0 \\
35.0 \\
34.5 \\
34.0 \\
33.0 \\
32.0 \\
30.0\end{array}$ & $\begin{array}{r}5.5 \times 10^{3} \\
2.0 \times 10^{3} \\
4.5 \times 10^{3} \\
6.0 \times 10^{6} \\
4.1 \times 10^{3} \\
>9.0 \times 10^{4} \\
>3.4 \times 10^{8} \\
>1.0 \times 10^{8} \\
>1.7 \times 10^{8} \\
>1.2 \times 10^{7}\end{array}$ & (2) \\
\hline $\begin{array}{l}M N F-162 \\
M N F-163 \\
M N F-235 \\
M N F-166\end{array}$ & $\begin{array}{l}649 \\
649 \\
649 \\
649\end{array}$ & $\begin{array}{l}1200 \\
1200 \\
1200 \\
1200\end{array}$ & $\begin{array}{l}\text { Helium } \\
\text { Helium } \\
\text { Helium } \\
\text { Helium }\end{array}$ & $\begin{array}{l}241.0 \\
221.0 \\
217.0 \\
214.0\end{array}$ & $\begin{array}{l}35.0 \\
32.0 \\
31.5 \\
31.0\end{array}$ & $\begin{array}{l}2.0 \times 10^{4} \\
5.1 \times 10^{5} \\
3.2 \times 10^{5} \\
1.1 \times 10^{8}\end{array}$ & \\
\hline
\end{tabular}


Table 2 (Continued)

High Cycle Fatigue Data for Incoloy $800 \mathrm{H}$ as a

Function of Test Environment and Temperature

\begin{tabular}{|c|c|c|c|c|c|c|c|}
\hline $\begin{array}{l}\text { Spec. } \\
\text { No. }\end{array}$ & $\begin{array}{l}\text { Test } \\
\left({ }^{\circ} \mathrm{C}\right)\end{array}$ & $\begin{array}{l}\text { Temp. } \\
\left({ }^{\circ} \mathrm{F}\right)\end{array}$ & $\begin{array}{c}\text { Test } \\
\text { Environment }\end{array}$ & $\begin{array}{l}\text { Cyclic } \\
\text { (MPa) }\end{array}$ & $\begin{array}{r}\text { Stress } \\
(\mathrm{ksi})\end{array}$ & $\begin{array}{r}\text { Cycles to } \\
\text { Failure (N) }\end{array}$ & Notes \\
\hline MNF-138 & 760 & 1400 & Air & 172.0 & 25.0 & $1.1 \times 10^{4}$ & \\
\hline MNF-139 & 760 & 1400 & Air & 152.0 & 22.0 & $5.4 \times 10^{4}$ & \\
\hline MNF -140 & 760 & 1400 & Air & 145.0 & 21.0 & $1.3 \times 106$ & \\
\hline MNF-141 & 760 & 1400 & Air & 138.0 & 20.0 & $4.0 \times 10^{6}$ & \\
\hline MNF-146 & 760 & 1400 & Air & 131.0 & 19.0 & $2.8 \times 10^{6}$ & \\
\hline MNF-147 & 760 & 1400 & Air & 124.0 & 18.0 & $1.8 \times 10^{6}$ & \\
\hline MNF-151 & 760 & 1400 & Air & 117.0 & 17.0 & $1.0 \times 10^{7}$ & \\
\hline MNF -152 & 760 & 1400 & Air & 103.0 & 15.0 & $1.4 \times 10^{8}$ & \\
\hline MNF-206 & 760 & 1400 & Air & 103.0 & 15.0 & $>3.4 \times 10^{8}$ & \\
\hline MNF-158 & 760 & 1400 & Air & 90.0 & 13.0 & $3.5 \times 10^{8}$ & \\
\hline MNF-145 & 760 & 1400 & Helium & 207.0 & 30.0 & $1.7 \times 10^{4}$ & \\
\hline MNF-149 & 760 & 1400 & Helium & 186.0 & 27.0 & $5.3 \times 10^{5}$ & \\
\hline MNF-143 & 760 & 1400 & Helium & 172.0 & 25.0 & $1.6 \times 10^{7}$ & \\
\hline MNF-242 & 760 & 1400 & Helium & 159.0 & 23.0 & $6.1 \times 10^{7}$ & \\
\hline MNF -142 & 760 & 1400 & Helium & 152.0 & 22.0 & $2.0 \times 10^{7}$ & \\
\hline MNF-151 & 760 & 1400 & Helium & 138.0 & 20.0 & $1.1 \times 10^{8}$ & \\
\hline MNF-160 & 760 & 1400 & Helium & 117.0 & 17.0 & $4.0 \times 10^{8}$ & \\
\hline MNF-231 & 871 & 1600 & Air & 124.0 & 18.0 & $3.3 \times 10^{4}$ & \\
\hline MNF-233 & 871 & 1600 & Air & 117.0 & 17.0 & $3.3 \times 10^{6}$ & \\
\hline MNF-245 & 871 & 1600 & Air & 117.0 & 17.0 & $3.2 \times 10^{5}$ & \\
\hline MNF-230 & 871 & 1600 & Air & 103.0 & 15.0 & $1.1 \times 10^{6}$ & \\
\hline MNF-232 & 871 & 1600 & Air & 83.0 & 12.0 & $6.6 \times 10^{6}$ & \\
\hline MNF-234 & 871 & 1600 & Air & 55.0 & 8.0 & $1.6 \times 10^{8}$ & \\
\hline MNF-241 & 871 & 1600 & Helium & 193.1 & 28.0 & $3.5 \times 10^{4}$ & \\
\hline MNF-239 & 871 & 1600 & Helium & 172.0 & 25.0 & $1.6 \times 10^{6}$ & \\
\hline MNF-238 & 871 & 1600 & Helium & 138.0 & 20.0 & $2.0 \times 106$ & \\
\hline MNF-236 & 871 & 1600 & Heli um & 124.0 & 18.0 & $2.6 \times 10^{6}$ & \\
\hline MNF-237 & 871 & 1600 & Helium & 103.0 & 15.0 & $1.2 \times 10^{7}$ & \\
\hline MNF-244 & 871 & 1600 & Helium & 83.0 & 12.0 & $9.0 \times 10^{6}$ & \\
\hline MNF-251 & 871 & 1600 & Helium & 62.0 & 9.0 & $9.6 \times 10^{6}$ & \\
\hline MNF -255 & 871 & 1600 & Helium & 48.0 & 7.0 & $>1.3 \times 10^{8}$ & \\
\hline
\end{tabular}


Table 3

High Cycle Fatigue Data for Incoloy 800H Thermally Aged in HTGR Helium Prior to Testing in Same Environment

\begin{tabular}{|c|c|c|c|c|c|c|c|c|}
\hline $\begin{array}{l}\text { Spec. } \\
\text { No. }\end{array}$ & $\begin{array}{l}\text { Aging } \\
\text { Time (h) } \\
\end{array}$ & $\begin{array}{l}\text { Cond. } \\
\text { Temp. }\left({ }^{\circ} \mathrm{C}\right)\end{array}$ & $\begin{array}{l}\text { Test } \\
\left({ }^{\circ} \mathrm{C}\right)\end{array}$ & $\begin{array}{l}\text { Temp; } \\
\left.\text { ( }{ }^{\circ} \mathrm{F}\right) \\
\end{array}$ & $\begin{array}{l}\text { Cyclic } \\
\mathrm{MPa} \\
\end{array}$ & $\begin{array}{c}\text { Stress } \\
\mathrm{ksi}\end{array}$ & $\begin{array}{r}\text { Cycles to } \\
\text { Failure (N) }\end{array}$ & Notes \\
\hline MNF-221 & 1500 & 760 & 760 & 1400 & 172.0 & 25.0 & $1.2 \times 10^{4}$ & \\
\hline MNF-223 & 1500 & 760 & 760 & 1400 & 152.0 & 22.0 & $6.5 \times 10^{4}$ & \\
\hline MNF-225 & 1500 & 760 & 760 & 1400 & 145.0 & 21.0 & $2.8 \times 10^{6}$ & \\
\hline MNF-222 & 1500 & 760 & 760 & 1400 & 138.0 & 20.0 & $4.3 \times 10^{6}$ & \\
\hline MNF-226 & 1500 & 760 & 760 & 1400 & 131.0 & 19.0 & $3.0 \times 10^{7}$ & \\
\hline MNF-224 & 1500 & 760 & 760 & 1400 & 117.0 & 17.0 & $8.8 \times 10^{7}$ & \\
\hline MNF-185 & 3000 & 760 & 760 & 1400 & 186.0 & 27.0 & $4.0 \times 10^{4}$ & \\
\hline MNF-194 & 3000 & 760 & 760 & 1400 & 159.0 & 23.0 & $5.5 \times 10^{5}$ & \\
\hline MNF-195 & 3000 & 760 & 760 & 1400 & 138.0 & 20.0 & $2.9 \times 10^{7}$ & \\
\hline MNF-197 & 3000 & 760 & 760 & 1400 & 124.0 & 18.0 & $9.8 \times 10^{7}$ & \\
\hline MNF-196 & 3000 & 760 & 760 & 1400 & 103.0 & 15.0 & $1.9 \times 10^{8}$ & \\
\hline MNF-191 & 6000 & 760 & 760 & 1400 & 186.0 & 27.0 & $9.3 \times 10^{4}$ & \\
\hline MNF-192 & 6000 & 760 & 760 & 1400 & 172.0 & 25.0 & $3.0 \times 10^{7}$ & \\
\hline MNF-188 & 6000 & 760 & 760 & 1400 & 157.0 & 23.0 & $1.6 \times 10^{7}$ & (1) \\
\hline MNF-205 & 6000 & 760 & 760 & 1400 & 138.0 & 20.0 & $1.2 \times 10^{8}$ & \\
\hline MNF-187 & 10500 & 760 & 760 & 1400 & 186.0 & 27.0 & $5.7 \times 10^{4}$ & (2) \\
\hline MNF-200 & 10500 & 760 & 760 & 1400 & 172.0 & 25.0 & $2.6 \times 10^{4}$ & \\
\hline MNF-201 & 10500 & 760 & 760 & 1400 & 165.0 & 24.0 & $1.7 \times 10^{4}$ & \\
\hline MNF-190 & 10500 & 760 & 760 & 1400 & 159.0 & 23.0 & $1.0 \times 10^{7}$ & (1) \\
\hline MNF-202 & 10500 & 760 & 760 & 1400 & 157.0 & 23.0 & $6.1 \times 10^{7}$ & \\
\hline MNF-199 & 10500 & 760 & 760 & 1400 & 138.0 & 20.0 & $4.9 \times 10^{7}$ & \\
\hline MNF-214 & 3000 & 871 & 871 & 1600 & 138.0 & 20.0 & $1.2 \times 10^{4}$ & \\
\hline MNF-216 & 3000 & 871 & 871 & 1600 & 124.0 & 18.0 & $1.4 \times 10^{5}$ & \\
\hline MNF-217 & 3000 & 871 & 871 & 1600 & 113.8 & 16.5 & $1.3 \times 10^{5}$ & \\
\hline MNF-215 & 3000 & 871 & 871 & 1600 & 103.0 & 15.0 & $2.7 \times 10^{6}$ & \\
\hline MNF-219 & 3000 & 871 & 871 & 1600 & 90.0 & 13.0 & $2.8 \times 10^{6}$ & \\
\hline MNF-220 & 3000 & 871 & 871 & 1600 & 79.0 & 11.5 & $1.6 \times 10^{7}$ & \\
\hline MNF -218 & 3000 & 871 & 871 & 1600 & 69.0 & 10.0 & $>5.9 \times 10^{7}$ & \\
\hline MNF-207 & 6000 & 871 & 871 & 1600 & 138.0 & 20.0 & $2.0 \times 10^{4}$ & \\
\hline MNF-210 & 6000 & 871 & 871 & 1600 & 124.0 & 18.0 & $2.5 \times 10^{5}$ & \\
\hline MNF-213 & 6000 & 871 & 871 & 1600 & 110.0 & 16.0 & $7.0 \times 10^{6}$ & \\
\hline MNF-208 & 6000 & 871 & 871 & 1600 & 103.0 & 15.0 & $8.8 \times 10^{5}$ & \\
\hline MNF-212 & 6000 & 871 & 871 & 1600 & 97.0 & 14.0 & $6.5 \times 10^{6}$ & \\
\hline MNF-211 & 6000 & 871 & 871 & 1600 & 90.0 & 13.0 & $>1.7 \times 10^{7}$ & (3) \\
\hline MNF-209 & 6000 & 871 & 871 & 1600 & 69.0 & 10.0 & $7.0 \times 10^{6}$ & \\
\hline
\end{tabular}

Notes:

1. Internal crack initiation point.

2. This series of tests recently completed. Not fully evaluated in this report.

3. Failed due to temperature over-run. 


\section{REFERENCES}

1. Kimba11, 0. F., and Roberts, D. I., Survey of Materials Data Needs for HTGR, General Atomic Co. Rept. GA-A13354, April 1975.

2. Huddle, R. A. U., "The Influence of HTR Helium on the Behavior of Metals in High Temperature Reactors", in Effects of Environment on Materials Properties in Nuclear Systems, Institution of Civil Engineers, London, 1971, pp. 203-212.

3. Wood, D. S., Farrow, M., and Burke, W. T., "A Preliminary Study of the Effect of Helium Environment on the Creep and Rupture Behavior of Type 316 Stainless Steel and Incoloy 800H", ibid., pp. 213-228.

4. Wood, D. S., Farrow, M., Baldwin, A. B., and Burke, W. T., "Creep Rupture Properties of Some High Temperature Reactor Circuit Materials in Helium", in Creep and Fatigue in Elevated Temperature Applications, Inst. of Mech. Eng., London, 1974, pp. 158.1-158.9.

5. Kondo, T., Kikuyama, and Shindo, M., "Corrosion and Fatigue of Superalloys in Simulated HTGR Helium Environments at Very High Temperatures", in Corrosion Problems in Energy Conversion and Generation, Electrochem. Soc., 1974, pp. 163-178.

6. Pearce, R. J., "The Compatibility of Alloy 800 in HTR Atmospheres", in A Status Review of Alloy 800, Brit. Nuc. Energy Soc., 1975, pp. 129-149.

7. Cook, R. H., "Creep and Fatigue of Alloy 800 in Helium", ibid., pp. 150169.

8. Betteridge, W., and Bates, H. G. A., "Studies of Alloy 800 in HTR Helium by the Dragon Project", ibid., pp. 170-184. 
9. Wood, D. S., Slattery, G., Wynn, J., Connaughton, M. D., and Lambert, M. E., "Preliminary Results of Effect of Environment on the Low Cycle Fatigue Behavior of Type 316 Stainless Steel and 9\% Cr Ferritic Steel", in The Influence of Environment on Fatigue, Inst. Mech. Eng., 1977 , pp. 11-20.

10. Cook, R. H., and Graham, L. W., "Chemical Behavior and Mechanical Performance on HTR Helium at High Temperatures", in Alloy 800, North Holland Pub. Co., 1978, pp. 309-326.

11. Chow, J. G. Y., and Soo, P., "Creep and Fatigue Properties of Incoloy $800 \mathrm{H}$ in a High Temperature Gas Cooled Reactor (HTGR) Helium Environment", ibid., pp. 331-336.

12. Forrest, J. E., "Mechanisms of Alloy 800 Corrosion in Helium", ibid., pp. $337-341$

13. Mazandarany, F. N., and Lai, G. Y., "Corrosion Behavior of Selected Structural Materials in a Simulated Steam Cycle High Temperature Gas Cooled Reactor Helium Environment", Nuc. Tech., Vol. 43, 1979, pp. 349365.

14. Hirano, T., Okada, M., Yoshida, H., and Watanabe, R., "Scale Morphology and Alloying Element Distribution in Incoloy 800 After High-Temperature Oxidation in Impure Helium", J. Nuc. Mat., Vol. 75, 1978, pp. 304-308.

15. Achter, M. R., "Effect of Environment on Fatigue Cracks", in Fatigue Crack Propagation, ASTM Spec. Tech. Pub. No. 415, 1967, pp. 181-202.

16. Orr, J., "A Review of Structural Characteristics of Alloy 800", in Alloy 800, North Holland Pub. Co., 1978, pp. 25-59. 
17. Soo, P., and Chow, J. G. Y., "Correlation of Low-Cycle and High-Cycle Fatigue Data for Solution Annealed Incoloy 800", in Alloy 800, North Holland Pub. Co., 1978, pp. 169-174.

18. Soo, P., and Chow, J. G. Y., "Development of a Procedure for Est imating High Cycle Fatigue Strength of Some High Temperature Structural Alloys", in Methods for Predicting Material Life in Fatigue, ASME, 1979, pp. 185-201.

19. Ebling, H. F., and Scheil, M. A., "Time-Temperature-Sensitization Diagrams for Types 304, 304L, and 316L Stainless Steels", in Advances in the Technology of Stainless Steels and Related Alloys, ASTM Spec. Tech. Public. No. 369, 1963, pp. 275-284.

20. Kaae, J. L., and Villagrana, R. E., "The Effect of Aging and Cold Working on the High-Temperature Low-Cycle Fatigue Behavior of Alloy $800 \mathrm{H}$ - Part I I, Low-Cycle Fatigue Behavior", ibid., pp. 181-184.

21. Dieter, G. E., Jr., Mechanical Metallurgy, McGraw-Hi11, 1961, Chapter 12. 